\title{
20. PETROGRAPHY AND MINERAL CHEMISTRY OF BASALTS FROM HOLES 519A, 520, 522B, AND 524-LEG 73 (SOUTH ATLANTIC) OF THE DEEP SEA DRILLING PROJECT ${ }^{1}$
}

\author{
M. F. Carman, Department of Geosciences, University of Houston, Houston, Texas \\ and
}

V. J. Dietrich and J. Sommerauer, Department of Earth Sciences, ETH-Zentrum, CH-8092 Zürich, Switzerland

\begin{abstract}
Basalt was encountered under sediments in four holes (519A, 520, 522B, and 524) on Leg 73. The rocks in three holes (519A, 520, and 522B) are typical somewhat evolved mid-ocean-ridge basalt (MORB) tholeiites that occur as pillows, flows, and sills. In Hole 524 there occur (1) an upper alkalic sequence of pillows and a sill enclosed in Cretaceous volcaniclastic sedimentary rocks and (2) a lower, moderately evolved, slightly alkalic tholeiite in a multiple sill, also injected into Cretaceous volcaniclastic rocks.

The tholeiites of Holes 519A, 520, and 522B display chemical, mineralogical, and petrographic features that are characteristic of MORB found elsewhere. The chilled margins of flows and pillows display a sequence of quench textures, and the interiors of the thicker flows and sills have the intersertal, intergranular, subophitic, and ophitic textures normally found in such rocks. The rocks are finely microphyric, with pre-eruptive plagioclase and sparse olivine microphenocrysts. Only pillows were encountered in Hole 520, and the rocks of that hole are distinctive in that they show a variolitic structure not seen in any of the other holes of Leg 73.

The tholeiites of Hole 524 are petrographically similar to those of Holes 519A to 522B, but they are more strongly microphyric, with all major silicate phases (olivine, plagioclase, and clinopyroxene) present as abundant to common microphenocrysts. The alkalic rocks of Hole 524 are distinctive in that (1) Fe-Ti oxides are present as pre-eruptive microphenocrysts in addition to the silicate phases, (2) the plagioclase grains are epitaxially mantled by alkalic feldspar, and (3) biotite and magnesioriebeckite occur as late-stage accessories.

The mineral phases have compositions well within the ranges of typical MORB from many locations: plagioclase microphenocrysts average $\mathrm{An}_{76-80}$, olivine $\mathrm{Fo}_{81-87}$, clinopyroxene microphenocrysts are close to $\mathrm{En}_{46} \mathrm{Fs}_{12} \mathrm{Wo}_{44}$ and zoned toward modest ferrosilite enrichment, titanomagnetites have average $64.4 \mathrm{~mol} . \%$ ulvospinel, and ilmenites average $8.2 \mathrm{~mol} . \%$ hematite. Trace elements are likewise well within the ranges reported from other oceanic sites.

Clinopyroxenes from the tholeitic multiple sill display an unusual compositional zoning in which $\mathbf{M}_{1}$ cations $(\mathrm{Fe}$, $\mathrm{Mg}, \mathrm{Mn}, \mathrm{Ti}$, and $\mathrm{Cr}$ ) show sympathetic variations from core to rim. There is a distinct drop in iron, manganese, and titanium and a concomitant increase in magnesium and chromium from inner core to outer core and then a strong reversal of these trends in the rims. The temporary reversal of the normal differentiation pattern from inner core to outer core in clinopyroxene occurs in both the early and late phases of the multiple sill and is not explained, although it may be related to variations in oxygen fugacity or the crystallization pattern of the Fe-Ti oxide minerals.
\end{abstract}

\section{INTRODUCTION}

Basalt was encountered at the anticipated base of the sedimentary sections in Holes 519A, 520, and 522B of Leg 73. In each case drilling was continued from a few meters (Hole 520) to a few tens of meters (Holes 519A and 522B) into the basalt. In all three holes the rock is typical tholeiitic mid-ocean-ridge basalt (MORB) (Dietrich et al., this vol.).

Hole 524, drilled on the south flank of the Walvis Ridge, is more complex, in that it contains an upper sequence of alkalic basalt pillows below which there is a slightly alkalic tholeiitic basalt in a multiple sill. The alkalic and tholeiitic rocks are separated by largely volcaniclastic sedimentary rocks, and the hole bottomed in a similar sedimentary sequence.

The four holes discussed here were located in a nearly east-west line away from the Mid-Atlantic Ridge (Fig. 1), and the basaltic rocks increase in age eastward,

\footnotetext{
${ }^{1}$ Hsü, K. J., LaBrecque, J. L., et al., Init. Repts. DSDP, 73: Washington (U.S. Govt. Printing Office).
}

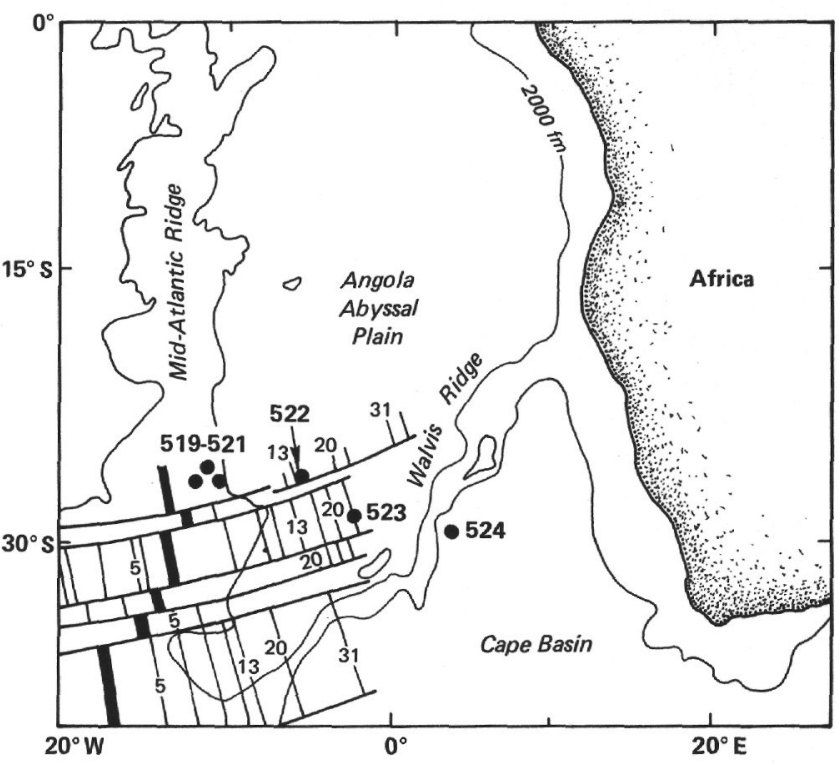

Figure 1. Leg 73 drill sites. Numbers between lines indicate seafloor magnetic anomalies. 
as expected. In Hole 519A, which is just east of the ridge $\left(11^{\circ} 40^{\prime} \mathrm{W}, 26^{\circ} 8^{\prime} \mathrm{S}\right)$, the sediments that rest on the basalt are upper Miocene. In Hole 520, which is a bit farther east $\left(11^{\circ} 11^{\prime} \mathrm{W}, 25^{\circ} 31^{\prime} \mathrm{S}\right)$, the sediments at the base of the sedimentary column are middle Miocene, whereas in Hole 522B the sediments that rest on the basalt are upper Eocene. In Hole 524, on the east flank of the Walvis Ridge, the basaltic rocks are enclosed in sedimentary rocks of Maestrichtian age. The alkalic and tholeiitic sills in this hole were dated by the K-Ar method at $64.9 \pm 0.8$ and $73.6 \pm 1.6$ m.y., respectively (Dietrich et al., this vol.).

The stratigraphy of the cooling units is described in detail in the site chapters and summarized in Figures 2 to 4 . The textural and structural evidence for pillows and the sill-like nature of the units displayed in those figures are also discussed in the site chapters.

The geochemistry of the basaltic rocks in the Leg 73 holes is discussed by Dietrich et al. (this vol.). This paper summarizes the petrography of the tholeiitic and alkalic basalts encountered on Leg 73, gives a synthesis of the textural relations of quenched rocks, and presents the results of mineral chemistry studies.

\section{TEXTURES AND STRUCTURES}

Most of the textural variations in the rocks of Leg 73 are typical of mid-ocean-ridge basalts and have been observed on previous legs (see especially Bryan, 1972; Natland, 1979; Kirkpatrick, 1979; Sato, 1979). The textures range from glassy quench textures in the rims of pillows and the thin upper margins of flows to relatively coarsegrained fabrics in the interiors of thick flows and sills. The textures of the rocks found in individual holes are described in detail in the site chapters. The intent of this chapter is to infer from the textural variations variations in cooling conditions and rock chemistry. Thus, it is possible to distinguish two groups of quench textures in chilled margins that reflect differences in magma chemistry, and within these groups strong variations in texture reflect differences in cooling rate.

\section{Terminology} lows.

The terms used in this discussion are defined as fol-

\section{Grain Size}

Grain sizes are as defined for Leg 52, with the addition of the term "very fine grained."

Thus, the scale is as follows:

\begin{tabular}{ll}
\hline Rock description & Grain size $(\mathrm{mm})$ \\
\hline Very coarse grained & 0.5 \\
Coarse grained & $0.1-0.5$ \\
Medium grained & $0.05-0.1$ \\
Fine grained & $0.01-0.05$ \\
Very fine grained & 0.01 \\
\hline
\end{tabular}

\section{Dendritic Shapes}

There is a range of dendritic shapes in the quenched rocks. The variation is especially pronounced in clino-
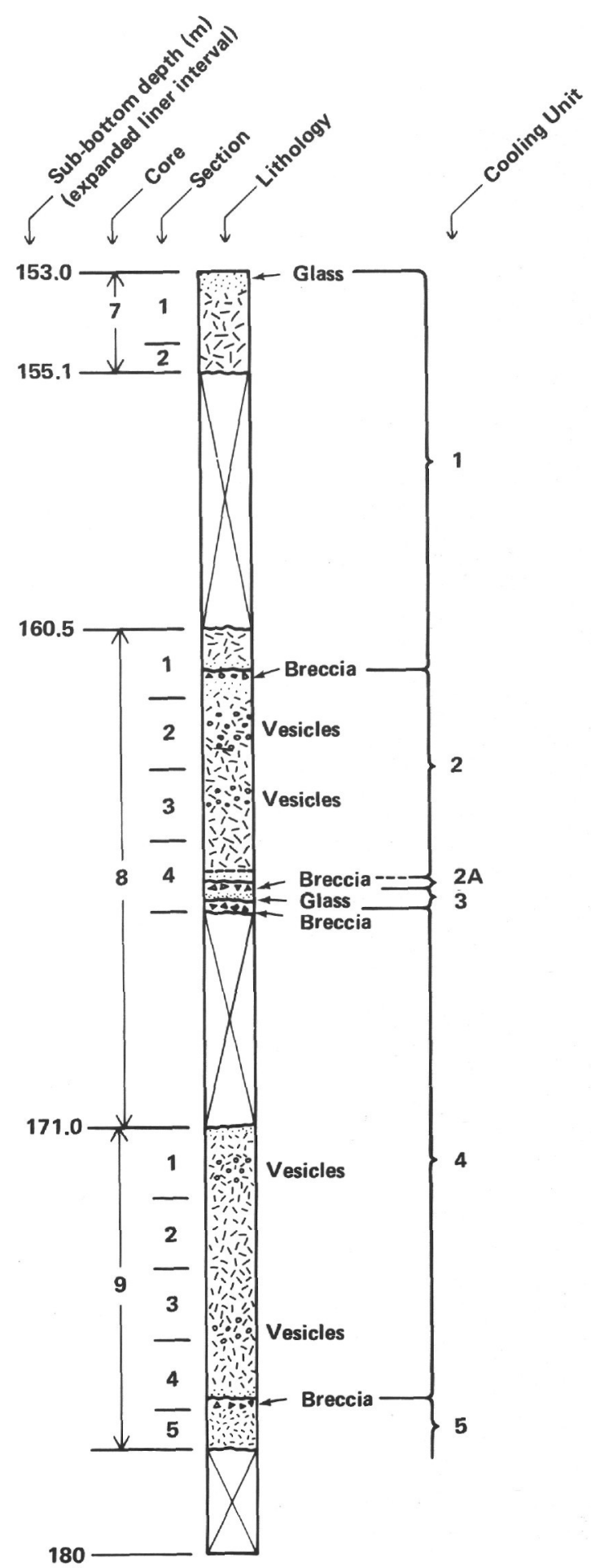

Figure 2. Occurrence of basaltic rocks in Hole 519A.

pyroxene. The following descriptive terms are used: simple dendritic (Pl. 1, Fig. 1) -fine- to very fine-sized clusters of very fine-grained spines that lack the larger-scale organization shown by plumose dendrites. Plumose dendritic (Pl. 1, Fig. 2)-fine- to coarse-sized clusters of very fine-grained spines that are arranged on both sides of and roughly perpendicular to a central axis. Combshaped dendritic (Pl. 1, Fig. 3)-a variety of plumose 


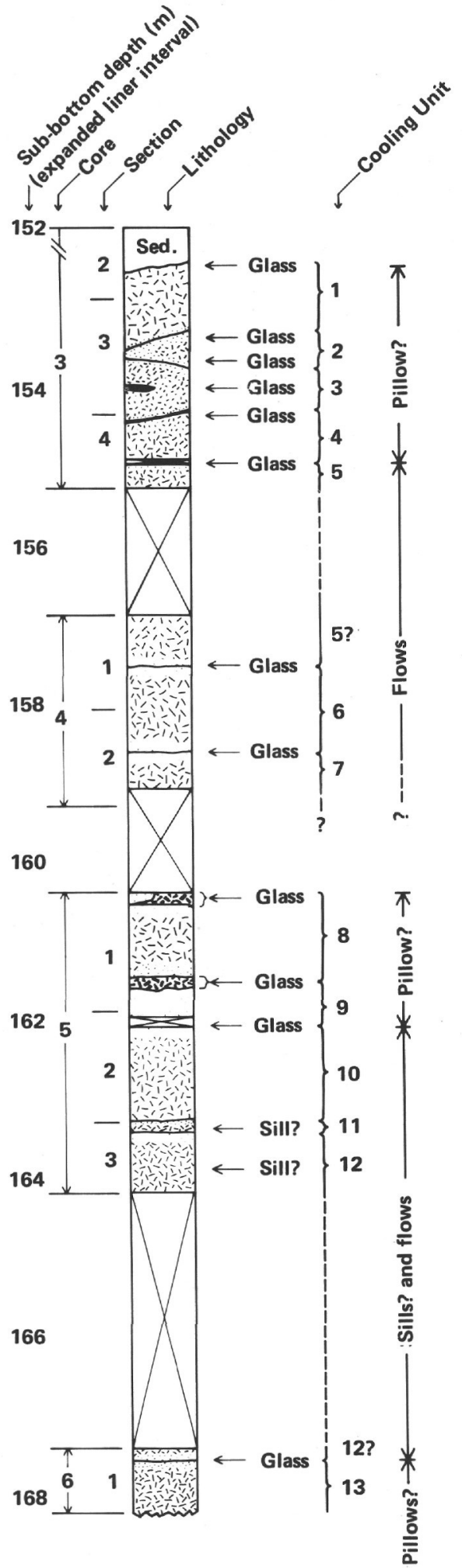

Figure 3. Occurrence of basaltic rocks in Hole 522B.

dendritic: the spines are aligned on only one side of an axis. Coarse dentritic (Pl. 1, Fig. 4)-gradational from plumose dendritic to boxy skeletal. Coarse- to very coarse-sized clusters of very fine- to medium-grained spines are arranged roughly perpendicular to an axis or radiate around a plagioclase core.

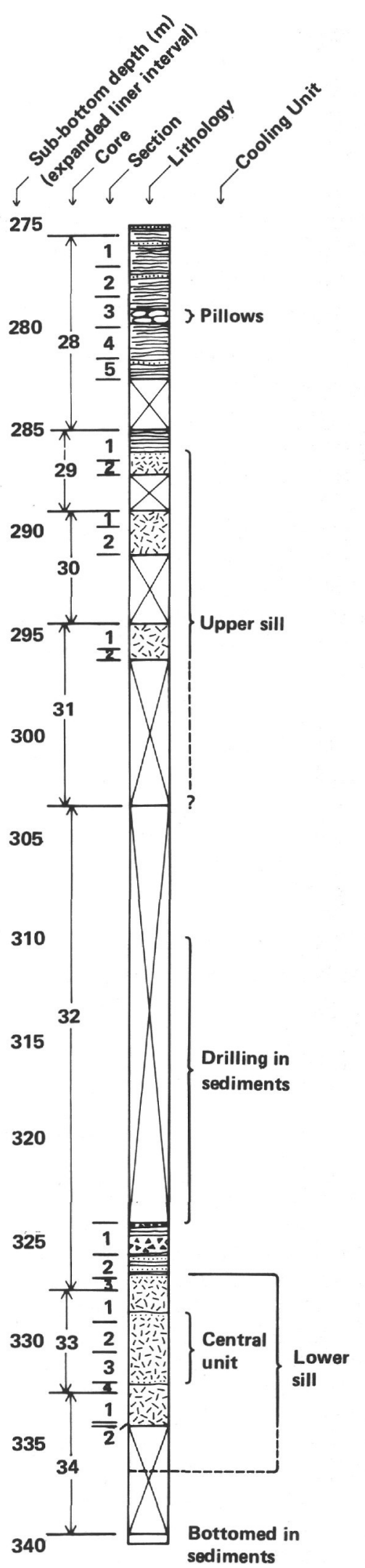

Figure 4. Occurrence of basaltic rocks in Hole 524. 


\section{Texture}

As one proceeds from chilled margins into the rock there are as many as six arbitrarily defined textures. They are described below in order of generally increasing coarseness.

\section{Zone 1: Glassy (Pl. 2, Fig. 1)}

Glass, with sparse microphenocrysts of olivine and plagioclase, increasingly mantled with cryptocrystalline spherulitic radial overgrowths as Zone 2 is approached. Overgrowths constitute less volume than microphenocrysts, and crystalline aggregates do not touch.

Zone 2: Glassy Spherulitic (Pl. 2, Fig. 2)

Zones are 1 to $2 \mathrm{~mm}$ thick. Spherulitic overgrowths equal or exceed central crystal core in volume. Spherulitic aggregates commonly touch, and glass occurs in relatively isolated interstices.

\section{Zone 3: Coalesced Spherulitic (Pl. 2, Fig. 3)}

Very fine quench texture; zones are 2 to $2.5 \mathrm{~mm}$ thick. No glass, spherulites are coarsened and coalesced into a continuous mass. Boundaries of spherulites are distinct and rather sharp. Fibers in the centers of spherulites coarsen and cause centers to darken in the portion of the zone more distant from glass.

\section{Zone 4: Sheaf-Shaped Spherulitic (Pl. 2, Fig. 4)}

Fine quench texture; zones are 10 to $12 \mathrm{~mm}$ thick. Spherulites dominate and have distinct flaring sheaf form (bow tie or fan shaped). Subordinate, simple, finely dendritic to plumose dendritic clinopyroxene is developed between spherulites.

\section{Zone 5: Plumose Dendritic (Pl. 1, Fig. 2)}

Fine quench texture; zones are $2+\mathrm{cm}$ thick. Similar to Zone 4, but plumose dendritic clinopyroxene is strongly developed and occupies at least as much space as spherulites, thus separating and surrounding them. Many spherulites are only partially formed.

\section{Zone 6: Coarse Dendritic (Pl. 1, Fig. 4)}

Coarse quench texture. More coarse grained than Zone 5; grain size is typically medium to coarse. The plagioclase is in euhedral lath-shaped (simple pinacoiddominated) grains, many of which show chain-link texture. The most striking feature is relatively coarse dendritic clinopyroxene that fills the spaces between plagioclase grains, which clearly shows how the growth, thickening, and coalescing of dendritic spine units reflect the transition to the subophitic and ophitic individuals of coarser textures.

Across Zones 1 to 5, thin elongate quench plagioclase crystals are sparse or absent in Zones 1 and 2 and sparse in Zone $3(1-5 \%)$. The crystals increase in number and size through Zone 4, becoming abundant (e.g., 20-25\%) in Zone 5. These crystals are typified by swallowtail, hollow boxy skeletal, and thinly tapered forms and have width-to-length ratios of $1: 2$ to $1: 45$, averaging $1: 20$ to $1: 25$.
An increase in grain size accompanies the textural changes. In most flows the rocks range from very fine to medium grained within 2 or $3 \mathrm{~cm}$ of a glassy rind, and grain size increases more gradually thereafter through coarse and very coarse grained. The centers of the thicker flows and sills are evenly very coarse grained in the range of 0.5 to $2.5 \mathrm{~mm}$ over all except the outer few centimeters of each unit. In pillows the finer textures may persist through several tens of centimeters. In general, the textures of plagioclase and olivine in the quenched rocks display the sequence of shapes shown by Lofgren et al. (1974) to be a function of cooling rate in quartznormative lunar basalts.

The four quench zones (Zones 3-6 inclusive) resemble those defined by Kirkpatrick (1979). The correlation is roughly as follows:

\begin{tabular}{|c|c|c|c|}
\hline \multicolumn{2}{|c|}{ This chapter } & \multicolumn{2}{|r|}{ Kirkpatrick (1979) } \\
\hline Zone & Description & Zone & Description \\
\hline & & 1 & Glass \\
\hline 1 & Glassy & 2 & $\begin{array}{l}\text { Glass with isolated olivine den- } \\
\text { drites and plagioclase spheru- } \\
\text { lites }\end{array}$ \\
\hline 2 & $\begin{array}{l}\text { Glassy } \\
\text { spherulitic }\end{array}$ & 3 & $\begin{array}{l}\text { Coalesced olivine dendrites and } \\
\text { partially coalesced plagioclase } \\
\text { spherulites with residual glass } \\
\text { between }\end{array}$ \\
\hline 3 & $\begin{array}{l}\text { Coalesced } \\
\text { spherulitic }\end{array}$ & 4 & $\begin{array}{l}\text { Fully coalesced plagioclase spheru- } \\
\text { lites with distinct spherulite } \\
\text { boundaries }\end{array}$ \\
\hline 4 & $\begin{array}{l}\text { Sheaf-shaped } \\
\text { spherulitic }\end{array}$ & 5 & $\begin{array}{l}\text { Fully coalesced bow-tie-shaped } \\
\text { plagioclase spherulites with in- } \\
\text { distinct spherulite boundaries }\end{array}$ \\
\hline 5 & $\begin{array}{c}\text { Plumose den- } \\
\text { dritic }\end{array}$ & 6 & $\begin{array}{l}\text { Microlite plagioclase with den- } \\
\text { ritic pyroxene between }\end{array}$ \\
\hline 6 & $\begin{array}{c}\text { Coarse den- } \\
\text { dritic }\end{array}$ & & \\
\hline
\end{tabular}

The term aphyric is used in describing most of the rocks of Leg 73. In fact, the textures are mostly microphyric in the fine-grained quenched phases; but these finer textures grade away from glassy rims into the coarser seriate intergranular, subophitic, and ophitic fabrics typical of the interior of most flows and the sills. The margins of the multiple tholeiitic lower sill of Hole 524 are finely phyric, with well-formed phenocrysts of plagioclase, olivine, and clinopyroxene in the range of 0.1 to $2.5 \mathrm{~mm}$ set in a spherulitic matrix. This texture grades into a coarse- to very coarse-grained seriate intergranular texture in the interior of the sill.

\section{Quench Textures}

Quench textures were found in the rocks from all holes. They occur through thicknesses of as much as $\mathbf{4 0}$ $\mathrm{cm}$ in pillows and as little as 2 to $3 \mathrm{~cm}$ along the margins of the sills and thickest flows.

The quench textures of the rocks in Hole 520 differ from the quench textures found in the other holes in that the spherulites of Zones 3 and 4 develop into larger and coarser sheaf-shaped to nearly spherical aggregates of curved plagioclase fibers with interstitial simple augite dendrites that are best termed variolitic (Pl. 2, Fig. 5 
and Pl. 1, Fig. 1). These fibers are not encountered in any other hole. In composition the rocks in Hole 520 are not greatly different from the other Leg 73 tholeiites, although the Hole 520 tholeiites are in general more evolved. For example, they have lower $\mathrm{Mg}$ numbers (0.54-0.56) than the tholeiites in Holes 519A and 522B, and all are quartz normative, in contrast to the tholeiite in Hole 524, which is significantly olivine normative (Dietrich et al., this vol.). Thus, if the variolitic fabric is the result of compositional variation, the variation is subtle and not easy to detect from the data at hand.

It was mentioned earlier that two types of quench textures can be distinguished that do reflect variations in magma chemistry. The quench textures in the alkaline pillows and upper sill of Hole 524 are different from those of the tholeiites described above in that each spherulite in the glassy and coalesced spherulitic zones contains a reticulate framework of rod-shaped ilmenitic dendrites (Pl. 2, Fig. 6). The rods thicken and the reticulate patches coarsen away from the chilled border. The abundant ilmenite clearly reflects the high titanium content of the alkalic magma. Other features that distinguish these rocks from the tholeiites are the absence of the sheaf-shaped spherulite zone (Zone 4 ) and the presence of common equant medium- to coarse-grained microphenocrysts of titanomagnetite.

The interiors of flows and sills are typified by coarser textures that are mostly seriate; particularly with respect to plagioclase and clinopyroxene. Clinopyroxene is mostly intergranular to subophitic, although it is ophitic in the three thickest flows in Hole 519A (Cooling Units, or C.U., 1, 2, and 4, Pl. 3, Fig. 1). Clinopyroxene in the coarse-grained lower sill of Hole 524 is distinctive in that it is bimodal in size distribution. There are abundant fine-grained, mostly subhedral intergranular grains that are often aggregated into irregular clusters and less abundant medium- to coarse-grained euhedral to subophitic grains that occasionally occur as glomerocrysts.

Intersertal patches are characteristic of the coarser textures of flows, but they are largely absent from the sills. These patches are most usually filled with the cryptocrystalline products of devitrified glass or the dendritic forms of plagioclase, clinopyroxene, and opaque minerals.

\section{Textural Interpretations}

\section{Hole 519A}

The rocks in Hole 519A that have quench textures also show clear evidence of pre-eruptive (first-generation) plagioclase crystallization. This plagioclase occurs as stubby, simply twinned phenocrysts that are only slightly zoned and appear singly or as glomerocrystic clusters (Pl. 3, Figs. 2 and 3). The phenocrysts are ubiquitous in all the cooling units in this hole, and a few of them contain small chrome-spinel inclusions. All the glassy margins in the hole also contain smaller seriate skeletal crystals of second-generation plagioclase and olivine. The crystals are frequently intergrown, with olivine at the core of a cluster of crudely radiating, hollow boxy plagioclase laths (Pl. 3, Fig. 4). The first-genera- tion plagioclase apparently grew slowly at near-equilibrium conditions, presumably in a magma chamber at depth, whereas the skeletal plagioclase and olivine crystals are believed to have grown during the upward passage and extrusion of the magma. In the chilled rocks, clinopyroxene and opaque minerals appear only as quenched dendritic phases.

Such chemical indicators as $\mathrm{Mg}$ number $(0.63-0.67)$, $\mathrm{TiO}_{2}$ (1.09-1.28 wt.\%), $\mathrm{Zr}$ (65-84 ppm), and $\mathrm{Y}$ (18-22 ppm) and rare earth element patterns (Dietrich et al., this vol.) all indicate a magma that is relatively primitive but somewhat evolved. The lack of early pyroxene indicates that the magma had not reached the olivine-plagioclase-clinopyroxene low pressure cotectic line before extrusion. On the basis of mineralogy alone it would appear that this magma lay in the primary plagioclase phase volume of the basalt tetrahedron at depth and moved to the plagioclase-olivine cotectic surface upon eruption. If so, however, the tholeiites of this hole could not have been derived simply by the crystal fractionation of olivine or plagioclase from a typical more primitive MORB liquid, which would have lain in the olivine primary phase volume.

The flow units of Hole 519A show a range in degree of differentiation with regard to such parameters as $\mathrm{Mg}$ number and titanium (Dietrich et al., this vol.). However, the lack of early olivine phenocrysts, the chemical evidence of a general increase in $\mathrm{Sr}$ with increasing differentiation, and the lack of a europium anomaly (Dietrich et al., this vol.) make it difficult to explain the systematic chemical variations between individual flow units simply by the crystal fractionation of olivine and plagioclase, although the fractionation of plagioclase alone does fit some of the data (Dietrich et al., this vol.).

\section{Hole 520}

The rocks in Hole 520 differ from those in Hole 519A in that they contain common relatively large olivine phenocrysts in the glassy margins and fine quench rocks. Some are euhedral, many are strongly skeletal in lantern-shaped grains, and many show rounded irregular re-entrants that indicate resorption (Pl. 3, Fig. 5). All of these features can be seen in a single thin section together with the very fine quenched olivines described below. Olivine also occurs as a sparse intergrowth with skeletal plagioclase microphenocrysts that are similar in morphology to the second-generation phenocrysts in the basalts of Holes 519A and 522B. Plagioclase, in addition to occurring in the intergrowths with olivine, occurs in sparse separate seriate skeletal microphenocrysts. Both the intergrowths and single crystals of olivine and plagioclase form the nuclei of variolitic clusters composed of finely dendritic plagioclase and clinopyroxene. Quench crystals of olivine composed of very fine-grained, highly skeletal chain-link individuals ( $\mathrm{Pl}$. 3, Fig. 6) cut across the dendritic fibers of the other phases in the varioles. The alignment of olivine dendrite chains parallel to the crystallographic directions of nearby olivine microphenocrysts in the glassy spherulitic zone (Pl. 3, Fig. 5) strongly suggests the existence of a parallel structure of 
$\mathrm{SiO}_{4}$ tetrahedra in the glass in the region surrounding the microphenocryst.

The presence in the same rock of both "equilibriumtype" olivine crystals that show resorption and later quench crystals could be explained by the decrease in pressure that occurs as magma rises to the surface. The crystals on the olivine solidus that form at depth under elevated pressure would move off the solidus into the liquid field again if the magma rose to the surface so rapidly that the drop in temperature of the liquid did not keep pace with the lowering of the temperature of the solidus with the drop in pressure. Upon extrusion the liquid could have supercooled below the solidus, giving rise to the quench grains present in the varioles. As at Hole 519A, the liquid was not on the olivine-plagioclase-clinopyroxene cotectic line at the time of eruption. The presence of a modest Eu anomaly (Dietrich et al., this vol.) suggests the fractionation of plagioclase in addition to olivine in the derivation of this magma.

\section{Hole 522B}

The textural relations of the flow units in Hole 522B are similar to those in Hole 519A, with two exceptions. In Flow Units 3, 6, 8, 9, and 13, in addition to the ubiquitous first-generation plagioclase phenocrysts there are sparse, euhedrally skeletal and resorbed(?) olivine phenocrysts (P1. 4, Fig. 1) in the quenched margins that are very similar to those in Hole 520 . The other difference is the occurrence, in glassy margins, of both clinopyroxene bow-tie intergrowths in clusters of second-generation plagioclase and olivine-plagioclase intergrowths like those in Hole 519A. As in the tholeiite of Hole 519A, the opaque minerals appear in only the finest quench phases. In this instance some early rapidly formed olivine was probably present at depth, but, as at Hole 519A, there is no clear evidence of significant early slowly grown olivine.

In chemistry the magma of Hole 522B is similar to that of Hole $519 \mathrm{~A}$, but it is slightly more evolved, as shown by $\mathrm{Mg}$ number $(0.59-0.65), \mathrm{TiO}_{2}$ (1.34-1.49 wt. \%), $\mathrm{Zr}$ (82-97 ppm), and Y (23-28 ppm). In addition, the amounts of rare earth elements are consistently slightly higher (Dietrich et al., this vol.). Early olivine and the occurrence of clinopyroxene in the second-generation phenocrysts show that the magma had reached the low pressure olivine-plagioclase-clinopyroxene cotectic line at the time of extrusion. Olivine relations can be explained in the same fashion as for Hole 520 .

\section{Hole 524}

The quenched phases of the alkaline rocks of the pillows and upper sill in Hole 524 contain sparse to common, relatively large tabular plagioclase and small titanomagnetite microphenocrysts together with sparser small olivine and very rare clinopyroxene microphenocrysts. These characteristics are consistent with the highly evolved nature of the rocks (low $\mathrm{Mg}$ numbers- 0.33 0.46; high $\mathrm{TiO}_{2}-3.5-4.3 \mathrm{wt} . \%$; $\mathrm{Zr}$ of $155-287 \mathrm{ppm}$; $\mathrm{Y}$ of 35-42 ppm; low $\mathrm{Cr}-10-21 \mathrm{ppm}$; and low $\mathrm{Ni}-$ 3-14 ppm; Dietrich et al., this vol.), which presumably places the liquid at a cotectic point where all major phases would form prior to extrusion.

The chilled tholeiitic basalt of the lower sill margins contains abundant relatively large plagioclase and less abundant smaller euhedral olivine and clinopyroxene. This basalt is the most evolved of the tholeiites $(\mathrm{Mg}$ numbers of $0.52-0.57 ; \mathrm{TiO}_{2}$ of $1.82-1.92 ; \mathrm{Zr}$ of $127-145$ ppm; and Y of 29-35 ppm; Dietrich et al., this vol.). Its composition indicates that all the major silicate phases were stable prior to intrusion.

\section{Crystallization Sequences}

In Hole 519A, the textural evidence in the quenched rocks suggests the sequence of crystallization illustrated in Figure 5. The sequence in Hole 522B is similar except for the earlier crystallization of some olivine, as evidenced by the presence of first-generation olivine euhedrons in certain rocks of some units. The magma in Hole 520 differed from that in Holes 519A: and 522B in that appreciable amounts of olivine crystallized early. Apparently plagioclase started to form only when rapid cooling had begun (Fig. 5). The tholeiitic multiple sill in Hole 524 has euhedral microphenocrysts of olivine, plagioclase, and clinopyroxene in the chilled facies, and the textures of the coarser rocks are seriate.

In the interior of the flows and sills in Holes 519A and 522B and the tholeiitic basalts of Hole 524, the paragenesis of major phases suggested by texture appears to be plagioclase + olivine, plagioclase \pm olivine + clinopyroxene, plagioclase + clinopyroxene $+\mathrm{Fe}-\mathrm{Ti}$ oxides.

The alkalic basalts in Hole 524 have relatively large euhedral microphenocrysts of all four major phases in their chilled facies, and the textures of coarser facies are

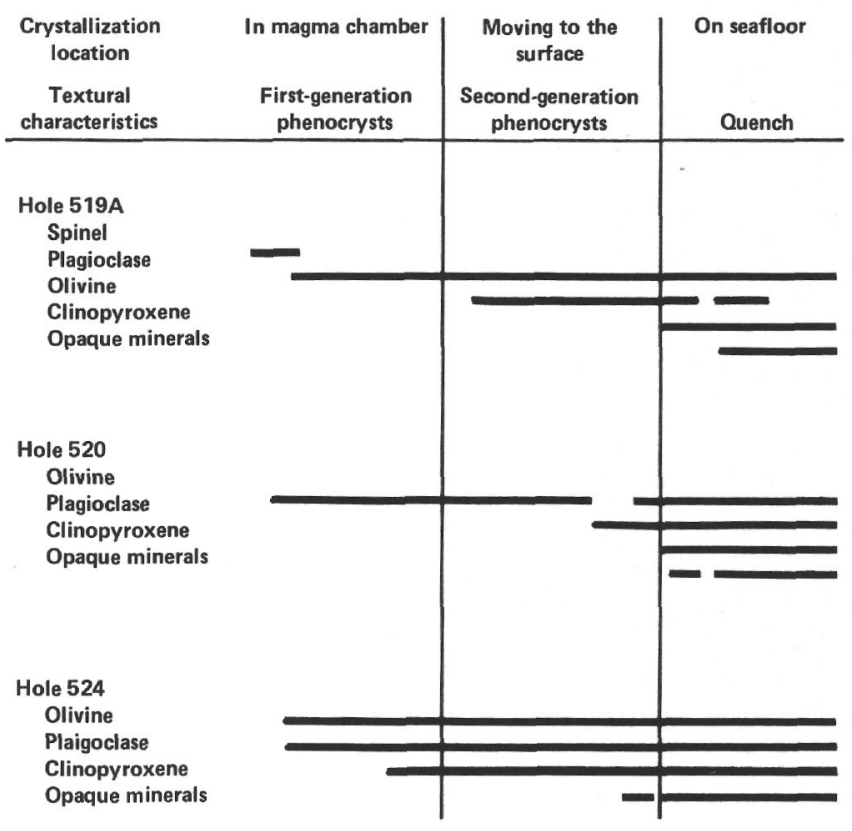

Figure 5. Sequence of crystallization of quenched tholeiitic magmas at sites of Holes 519A, 520, and 524 prior to and during eruption. 
distinctly seriate. The plagioclase phenocrysts are largest and by far the most abundant, suggesting that they started to form earliest.

\section{Small-Scale Structures}

\section{Segregation Vesicles}

The rocks of Hole 522B contain common small $(0.05-1.2 \mathrm{~mm}$ ) segregation (or shrinkage) vesicles (Pl. 4, Figs. 2-5). The vesicles appear as spherical features bounded by tangentially arranged plagioclase microlites and are filled with ultra-fine-grained (mostly less than $0.01 \mathrm{~mm}$ ) material. The phases identified most often are abundant titanomagnetite (often 25-50 vol. \%), dendritic clinopyroxene, plagioclase microlites, very fine spherulites (plagioclase and pyroxene mixtures), and smectite or chlorite. A common feature is a core of calcite. Similar features have been described from Australian pillow lavas (Smith, 1967) and other DSDP cores (Leg 37, Barager et al., 1977; Leg 46, Sato, 1979; Leg 51, Donnelly, Francheteau, et al., 1979). All of the fabric relations described by Sato $(1979$, p. 283$)$ are observed in the rocks of Hole 522B.

Such vesicles are believed to have filled with magma upon the contraction during cooling of the vapor phase that first occupied the vesicle. Smith (1967) suggested a downslope movement of submarine basalt during cooling to account for a pressure increase to cause the filling. However, as pointed out in Donnelly, Francheteau, et al. (1979), "a larger change in the specific volume of water during cooling would occur at fixed higher ambient water pressure, and ... the occurrence of shrinkage vesicles should be an indication of an abyssal marine environment" (p. 65).

Microprobe analyses of phases from inside and outside the vesicles in the quenched interior of a pillow (Sample 522B-3-3, 135-137 cm, Cooling Unit 3) show relatively small differences between comparable phases. Variations are distinct for vesicles in the center of a flow, however (Sample 522B-4-1, 4-6 cm, Table 1; the flow is interpreted to be at least $1 \mathrm{~m}$ thick). As might be expected, the quenched rock from the pillow shows slight differentiation, whereas the more slowly cooled rock from the flow shows the same trends in clinopyroxene and plagioclase composition as appear between phenocryst cores and groundmass grains throughout the tholeiitic rocks. The vesicle filling in the flow clearly occurred after significant crystallization of plagioclase and clinopyroxene had produced a liquid relatively rich in $\mathrm{Fe}, \mathrm{Na}$, and $\mathrm{K}$. The similarity of the titanomagnetites inside and outside the vesicle in Sample 522B, 4-1, 4-6 cm, together with a much higher concentration of the opaque mineral within the vesicle, suggest that the vesicle filling occurred before much, if any, crystallization of opaque minerals began in the host rock.

\section{Contraction Fractures}

The pillows and upper sill of Hole 524 display thin discontinuous veinlets that are oriented parallel to the cooling surfaces (Pl. 4, Fig. 6). They range from less
Table 1. Composition of phases in segregation vesicles and host rock (mol.\%). Sample 522B-4-1, 4-6 cm, flow, Cooling Unit 5.

\begin{tabular}{lcc}
\hline \multicolumn{1}{c}{ Phase } & Inside vesicle & Outside vesicle \\
\hline $\begin{array}{c}\text { Clinopyroxene } \\
\text { Crystal type }\end{array}$ & Coarse dendritic & Subophitic \\
Composition: ${ }^{\mathrm{a}}$ & 30.7 & 47.7 \\
En & 32.4 & 11.8 \\
Fs & 36.9 & 40.5 \\
Wo & 3 & 4 \\
Number of analyses & & \\
Plagioclase & & \\
& & Second-generation \\
Crystal type & Quench microlite & phenocryst \\
Composition: & 53.6 & 82.5 \\
An & 45.7 & 17.4 \\
Ab & 0.7 & 0.1 \\
Or & 2 & 2 \\
Number of analyses & & \\
Titanomagnetite & 62.4 & 65.6 \\
Ulvospinel & 2 & 2 \\
Number of analyses & &
\end{tabular}

a Composition represents the average of the analyses.

than 1 to 2 or $3 \mathrm{~mm}$ thick, and they thicken, become more widely spaced, and coarsen in texture away from the contact. Near the contact they are filled with calcite, but the thicker ones a few centimeters from the contact are filled mostly with alkali feldspar (Hole 524 site chapter, Pl. 1, Fig. 5). No such features were found in any tholeiites, but they are highly characteristic of mafic to intermediate alkaline shallow intrusive rocks (Carman et al., 1975). They have been interpreted as fractures formed during contraction upon cooling when a relatively rigid framework of crystals had already formed but a late feldspathic residuum between the crystals was still capable of oozing into the fractures.

\section{MODAL ANALYSES}

The modes of those rocks coarse enough for the measurement of all of the major phases are given in Table 2 . In the modal analyses, counts were continued until none of the measured items changed more than $0.5 \%$ in three successive 100-point counts. This standard entailed between 1800 and 2300 counts for each sample. In most samples the largest uncertainty is in the olivine because it is largely altered to smectite or other phyllosilicates except in the glassy quenched rocks. Therefore, much of the counting was based on the pseudomorphic shape of grains. Normally only those grains that were clearly pseudomorphs were counted as olivine, but even that choice was often quite subjective. In general, however, it is believed that the olivine values are perhaps a bit low because of this criterion for their determination. The modes pretty well reflect the chemistry of the rocks, but they do not confirm the suggestions of possible crystal settling in Flows 1 and 4 of Holes 519A, nor of preferential crystal concentration in the lower sill of Hole 524, both of which are suggested by the bulk chemistry (Dietrich et al., this vol.). 
Table 2. Modal analyses (vol.\%).

\begin{tabular}{|c|c|c|c|c|c|c|c|c|c|c|}
\hline $\begin{array}{c}\text { Core-Section } \\
\text { (interval in cm) }\end{array}$ & $\begin{array}{c}\text { Cooling } \\
\text { Unit }\end{array}$ & Plagioclase & $\begin{array}{c}\text { Clino- } \\
\text { pyroxene }\end{array}$ & Olivine & $\begin{array}{l}\text { Opaque } \\
\text { minerals }\end{array}$ & Apatite & Biotite & Amphibole & Other ${ }^{\mathrm{a}}$ & Vesicles \\
\hline \multicolumn{11}{|l|}{ Hole 519A } \\
\hline $7-2,46-58$ & 1 & 44.5 & 31.5 & 5 & 4 & - & - & - & 14.5 & - \\
\hline $8-1,26-37$ & 1 & 49 & 31.5 & 4 & 6 & - & - & - & 9.5 & - \\
\hline $8-1,36-46$ & 1 & 47.5 & 31 & 4 & 5.5 & - & - & - & 12 & - \\
\hline $8-3,87-95$ & 2 & 45.5 & 33.5 & 3 & 7 & - & - & - & 11 & - \\
\hline $8-4,107-117$ & 3 & 45.5 & 41.5 & 4 & 5.5 & - & - & - & 3.5 & - \\
\hline $9-4,41-47$ & 4 & 50 & 31.5 & 3 & 6.5 & - & - & - & 9 & - \\
\hline $9-4,77-80$ & 4 & 53 & 28 & 4.5 & 4.5 & - & - & - & 10 & - \\
\hline \multicolumn{11}{|l|}{ Hole 520} \\
\hline $31-1,6-8$ & - & 37.5 & 28.5 & 5 & 5 & - & - & - & 24 & 0.1 \\
\hline $31-1,7-10$ & - & - & - & 5 & - & - & - & - & 95 & - \\
\hline \multicolumn{11}{|l|}{ Hole 522B } \\
\hline $4-1,26-31$ & 5 & 46 & 30.5 & 1.5 & 7 & - & - & - & 14 & - \\
\hline $4-2,2-9$ & 6 & 51 & 28.5 & 2.5 & 7.5 & - & - & - & 10.5 & 0.5 \\
\hline $4-2,36-40$ & 6 & 45 & 36 & 2 & 8.5 & - & - & - & 8.5 & - \\
\hline $4-2,103-105$ & 7 & 34.5 & 45.5 & 1 & 7 & - & - & - & 12 & 1.1 \\
\hline $5-1,58-60$ & 8 & 42.5 & 41 & 1 & 6 & - & - & - & 9.5 & 1.4 \\
\hline $5-2,126-130$ & 10 & 44.5 & 34 & 3 & 8 & - & - & - & 10.5 & 1.0 \\
\hline $5-3,3-6$ & 11 & 40 & 47.5 & 3 & 4.5 & - & - & - & 5 & 1.9 \\
\hline $5-3,7-11$ & 11 & 45 & 32 & 1.5 & 10.5 & - & - & - & 10.5 & 0.7 \\
\hline $5-3,28-34$ & 12 & 45 & 36.5 & 1.5 & 7.5 & - & - & - & 9.5 & 1.9 \\
\hline $6-1,75-77$ & 13 & 49 & 37 & 1 & 5 & - & - & - & 8 & - \\
\hline \multicolumn{11}{|l|}{ Hole 524} \\
\hline $29-2,43-46$ & Upper sill & 45.5 & 11.5 & 0.5 & 12 & 3.5 & 0.5 & - & 26.5 & - \\
\hline $30-2,126-129$ & Upper sill & 47.5 & 11.5 & 1 & 11.5 & 3.5 & 1 & 0.5 & 23.5 & - \\
\hline $31-1,43-46$ & Upper sill & 47 & 11 & 2 & 9 & 4 & 1 & tr & 26 & - \\
\hline $31-1,75-80$ & Upper sill & 46 & 11.5 & 1 & 10.5 & 3 & 1 & - & 27 & - \\
\hline $31-1,80-84$ & Upper sill & 50.5 & 9.5 & 2.5 & 10 & 3 & 0.5 & $\operatorname{tr}$ & 24 & - \\
\hline $31-1,108-111$ & Upper sill & 49 & 9.5 & 2.5 & 9.5 & 3 & 1.5 & $\operatorname{tr}$ & 25 & - \\
\hline $31-2,87-89$ & Upper sill & 50.5 & 10 & 1 & 8.5 & 2 & 1 & - & 27 & - \\
\hline $32-2,127-133$ & $\begin{array}{l}\text { Lower sill } \\
\text { upper part }\end{array}$ & 50.5 & 28 & 3.5 & 9 & - & - & - & 9 & 3.7 \\
\hline $32-3,40-44$ & $\begin{array}{l}\text { Lower sill } \\
\text { upper part }\end{array}$ & 50.5 & 26.5 & 7 & 6 & - & - & - & 10 & - \\
\hline $33-1,0-4$, Piece a & $\begin{array}{l}\text { Lower sill } \\
\text { upper part }\end{array}$ & 54.5 & 27.5 & 6.5 & 6.5 & - & - & - & 5 & - \\
\hline 33-1, 0-4, Piece b & $\begin{array}{l}\text { Lower sill } \\
\text { upper part }\end{array}$ & 55.5 & 28 & 9.5 & 6 & - & - & - & 1 & 0.5 \\
\hline $33-1,8-11$ & $\begin{array}{l}\text { Lower sill } \\
\text { upper part }\end{array}$ & 51.5 & 26 & 10.5 & 6 & - & - & - & 6 & - \\
\hline $33-1,33-36$ & $\begin{array}{l}\text { Lower sill } \\
\text { upper part }\end{array}$ & 51.5 & 25 & 10.5 & 8 & - & - & - & 5 & - \\
\hline $33-1,112-116$ & $\begin{array}{l}\text { Lower sill } \\
\text { upper part }\end{array}$ & 49.5 & 28.5 & 10.5 & 7 & - & - & - & 4.5 & - \\
\hline $33-2,29-32$ & $\begin{array}{l}\text { Lower sill } \\
\text { center }\end{array}$ & 53.5 & 23.5 & 12.5 & 6.5 & - & - & - & 4 & - \\
\hline $33-2,64-69$ & $\begin{array}{l}\text { Lower sill } \\
\text { center }\end{array}$ & 50.5 & 24.5 & 11 & 6 & - & - & - & 8 & - \\
\hline $33-2,123-126$ & $\begin{array}{l}\text { Lower sill } \\
\text { center }\end{array}$ & 52 & 26.5 & 9.5 & 9 & - & - & - & 3 & - \\
\hline $33-3,82-85$ & $\begin{array}{l}\text { Lower sill } \\
\text { center }\end{array}$ & 49.5 & 26.5 & 8.5 & 7.5 & - & - & - & 8 & - \\
\hline $33-3,136-141$ & $\begin{array}{l}\text { Lower sill } \\
\text { center }\end{array}$ & 50 & 28.5 & 8 & 8 & - & - & - & 5.5 & - \\
\hline $34-1,33-36$ & $\begin{array}{l}\text { Lower sill } \\
\text { lower part }\end{array}$ & 53.5 & 27 & 9.5 & 7.5 & - & - & - & 2.5 & - \\
\hline $34-1,74-79$ & $\begin{array}{l}\text { Lower sill } \\
\text { lower part }\end{array}$ & 51.5 & 29 & 8.5 & 7.5 & - & - & - & 3.5 & - \\
\hline $34-1,130-131$ & $\begin{array}{l}\text { Lower sill } \\
\text { lower part }\end{array}$ & 50 & 28.5 & 9 & 8 & - & - & - & 4.5 & - \\
\hline $34-2,18-21$ & $\begin{array}{l}\text { Lower sill } \\
\quad \text { lower part }\end{array}$ & 51.5 & 27 & 10.5 & 8 & - & - & - & 3 & - \\
\hline
\end{tabular}

\section{MINERAL CHEMISTRY}

\section{Analytical Techniques}

Mineral compositions were analyzed by using an Ames Research Laboratory electron microprobe, Type SEMQ, equipped with four motor-driven X-ray spectrometers and two fixed X-ray monochromators (set for $\mathrm{SiK}_{\alpha}$ and $\mathrm{MgK}_{\alpha}$ respectively). The analyses were performed with an acceleration voltage of $15 \mathrm{kV}$, a sample current (measured on brass) of $20 \mathrm{nA}$, and a minimum electron beam size, according to the parameters above, of $0.2 \mu \mathrm{m}$. For each analysis as many as 10 elements were determined (Tables 3-9). Natural silicates and oxides provided reference intensities.
Count times were used that yielded a standard deviation of the counting statistics of less than $1 \%$ for minor elements. As many as 10 analyses were averaged to determine the mineral compositions. The accumulated counts were corrected on line for background, drift, and deadtime with a PDP-11/05 computer. Correction procedures for $\mathrm{X}$-ray absorption, $\mathrm{X}$-ray fluorescence (by characteristic and continuum excitation, respectively), and atomic number effects were based on the ZAF correction program written at the Eidgenössische Technische Hochschule Zürich for the Control Data Corporation Cyber 720 computer system. Water, although not shown in the tables, was accounted for in the ZAF correction procedure for all hydrous phases. 


\section{Olivine}

Olivine occurs as apparently partially resorbed microphenocrysts in the chilled rocks of Holes 520 and 522B and as small euhedral pseudomorphic microphenocrysts in all rocks of Hole 524. It usually occurs as subhedral, anhedral, and lantern-shaped or chain-link grains and intergrowths, with plagioclase as second-generation microphenocrysts in chilled phases. In the coarser phases it is euhedral, intergranular, or ophitically intergrown with plagioclase.

Olivine is very rarely fresh in any except the glassy or spherulitic phases of the Leg 73 basalts. As a result, the analyses of olivine are almost exclusively of relatively small grains in such rocks, and compositional zoning in the larger and more slowly grown grains in the coarser phases could not be tested. The olivines in both the alkalic and tholeiitic rocks of all four holes fall within a relatively narrow range $\left(\mathrm{Fo}_{81-88}\right)$. Rocks from the tholeiitic lower sill were not analyzed for olivine because it had all been altered to smectite or chlorite.

Figure 6 illustrates the compositional variation in the various cooling units in each hole, and Table 3 gives representative chemical analyses. No significant zoning was detected in the microprobe study; however, a more detailed study might well show some zoning, especially in Cooling Unit 1 of Hole 519A, which shows the widest range of composition $\left(\mathrm{Fo}_{82-87}\right)$. As shown in the representative analyses, traces of $\mathrm{Ca}$ and $\mathrm{Mn}$ are ubiquitous and traces of $\mathrm{Cr}$ and $\mathrm{Al}$ are common; however, no pattern was detected in these elements in the present examination.

Although the data are sparse, they seem to suggest that the olivines may reflect the state of magmatic evolution of the cooling units in which they occur. The Fo values for Cooling Unit 2 of Hole 519A are higher (84.5 and 86.4) than those of Cooling Unit 4 (81.3 and 81.9 ) and as high or higher than the average of Cooling Unit 1 (84.5). Cooling Unit 2 is less evolved than Units 1 and 4, according to such criteria as $\mathrm{Mg}$ number (which is 0.67 for C.U. 2, 0.65 for C.U. 4, and 0.64 for C.U. 1; Dietrich et al., this vol.), and the olivine compositions perhaps reflect this. These relations would support the conclusion that the olivines in the rocks in Hole 519A started to crystallize during eruption (second-generation microphenocrysts) and thus reflect the degree of magmatic evolution of the liquid at that time. The magma of Hole 520 is distinctly more evolved than that of Hole 519A (e.g., Mg number ranges from 0.54 to 0.56 ; Dietrich et al., this vol.), and the Fo values for the Hole 520 olivines are among the lowest measured (81.6-83.3), even though those probed are microphenocrysts in glass and apparently started to crystallize prior to eruption. The magma of Hole 522B is slightly more evolved than that of Hole 519A (e.g., Mg number ranges from 0.60 to 0.63; Dietrich et al., this vol.), but the olivines have Fo contents that cluster narrowly in the range from 85.1 to 86.2 , with an average of 85.7 , slightly above the average at Hole 519A. However, the textural evidence indicates that the grains analyzed are likely to be first-generation microphenocrysts and as such might not reflect the state of magmatic evolution quite as closely as do those of Hole 519A.

\section{Feldspar}

The feldspars of the Leg 73 basalts are, of course, predominantly An-rich plagioclase, but the alkalic rocks of Hole 524, having undergone some in situ differentiation, show a range of ternary and alkali feldspars that include Na-sanidine, anorthoclase, and nearly pure albite and K-feldspar.

\section{Plagioclase}

In all rocks except those of Hole 520, plagioclase occurs as stubby, essentially unzoned, simply twinned, single and glomerocrystic first-generation microphenocrysts and as smaller, thinly tabular or columnar, zoned, finely twinned, hollow skeletal second-generation microphenocrysts. The latter are often intergrown as crudely radial clusters with olivine or, in some cases, clinopyroxene at the core of the intergrowth. Plagioclase in strongly quenched rock occurs as highly skeletal, swallowtailed and tapered grains, and as finely tapered spines on first- and second-generation microphenocrysts.

The compositions of representative plagioclases are given in detail in Table 4 and summarized in Figure 7. The plagioclase is typical of MORB. First-generation microphenocrysts average $\mathrm{An}_{80} \mathrm{~mol} . \%$ and range between $\mathrm{An}_{74}$ and $\mathrm{An}_{87}$, whereas second-generation grains are more albite rich, averaging $\mathrm{An}_{67}$ and usually ranging from $A n_{76}$ to $\mathrm{An}_{47}$. As might be expected, the quench grains are most variable. They average $\mathrm{An}_{51}$ but range from $\mathrm{An}_{72}$ to $\mathrm{An}_{24}$. In the pillows and flows of Holes $519 \mathrm{~A}, 520$, and 522B, compositional zoning in the firstgeneration plagioclase microphenocrysts is limited to a range of about $5 \% \mathrm{An}$. In second-generation grains the range is generally about $10 \% \mathrm{An}$, although in one case a range of $15 \%$ was measured. The diabasic lower sill of Hole 524 has the coarsest textures among the tholeiitic rocks of Leg 73, and the larger of the seriate plagioclase grains commonly show zoning of 10 to $15 \%$ An.

The potassium content of first- and second-generation microphenocrysts is essentially the same (Or of 0.1-0.4 mol.\%), but that of the quenched grains is higher, as is to be expected, averaging Or of 0.4 to 1.4 mol.\%. All grains show a small amount of iron. In firstgeneration grains $\mathrm{FeO}$ is $0.5 \mathrm{wt} . \%$ or less; in secondgeneration grains it ranges from slightly more than 0.5 wt. $\%$ to just under $1 \mathrm{wt} . \%$, and in quench phases the range is from 0.6 to $1.3 \mathrm{wt} . \%$. There are small amounts (usually 0.2 to $0.3 \mathrm{wt} . \%$ ) of magnesium in nearly all plagioclase grains, but content ranges from 0.1 to 0.6 wt. \%. Some grains show trace amounts of manganese.

The iron content of plagioclase in the tholeiitic rocks reflects the crystallization history of other phases, as demonstrated by Ayuso et al. (1976) and Sinton and Byerly (1980). A plot of $\mathrm{Fe}^{+2}$ cations against the An content of the tholeiitic rocks of Holes 519A, 522B, and 524 (Fig. 8) shows that $\mathrm{Fe}$ content remains nearly constant as An decreases to about $\mathrm{An}_{70}$; at that point $\mathrm{Fe}$ content begins to rise, peaking at about $\mathrm{An}_{50-55}$ and then grad- 

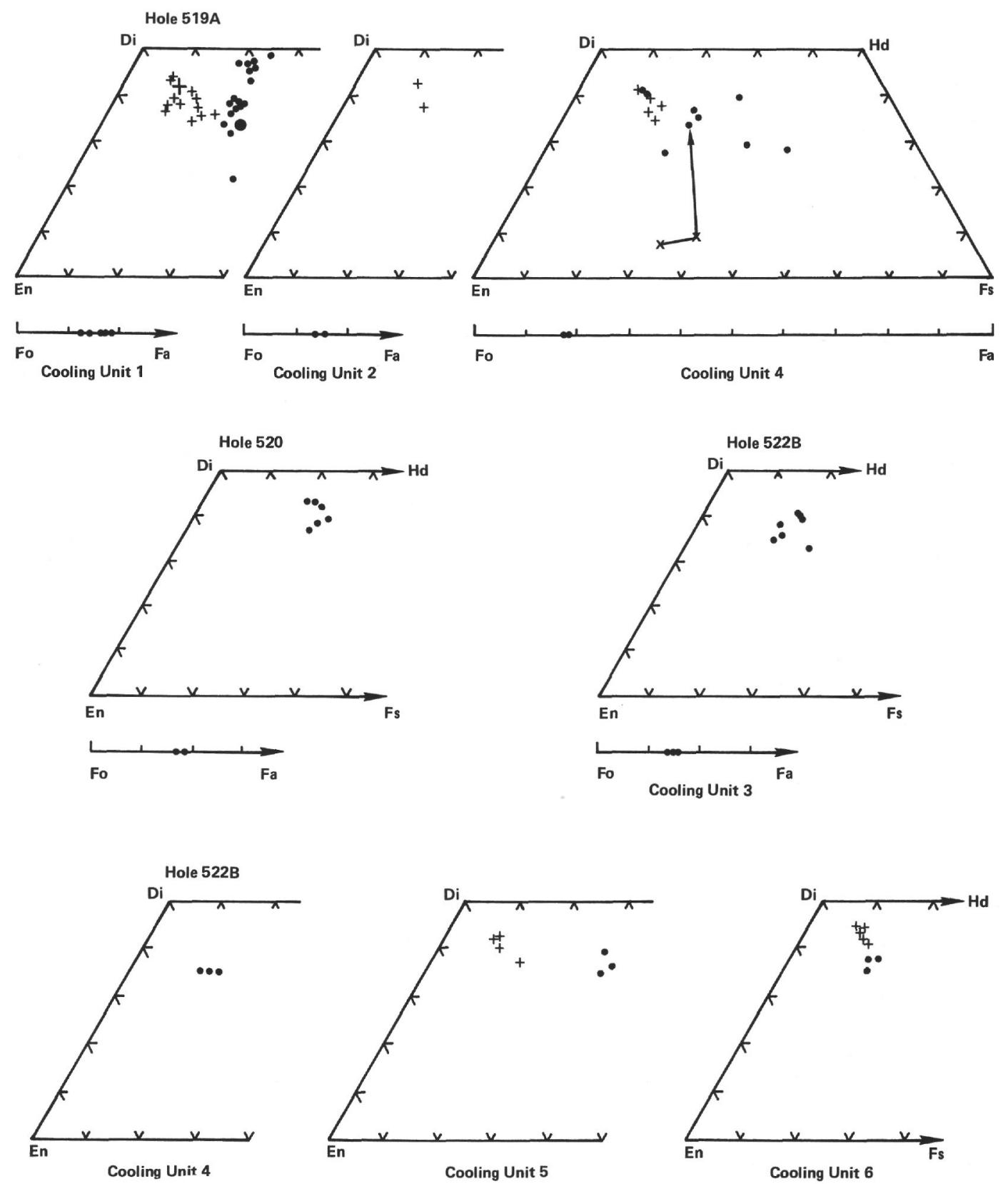

Figure 6. Olivine and clinopyroxene compositions by cooling unit (mol.\%). Larger symbols indicate two or more analyses of essentially the same composition.

ually decreasing as An drops. Figures 1 and 2 in Plate 5 illustrate crystal zones that correspond to some of the data in Figure 8.

The authors cited correlate the rise in $\mathrm{Fe}$ that begins at $\mathrm{An}_{70}$ to the beginning of the crystallization of pyroxene. The peak and subsequent decrease in iron with decreasing An is ascribed by Sinton and Byerly (1980) to the beginning of the crystallization of $\mathrm{Fe}-\mathrm{Ti}$ oxides. The parageneses deduced from textures fit these conclusions, in that the sequence of crystallization in all of the tholeiitic rocks shows plagioclase, clinopyroxene, and $\mathrm{Fe}-\mathrm{Ti}$ oxides to have formed in that order.

The plagioclase in the pillows of the alkalic rocks in Hole 524 appears as sparse, altered first-generation and unaltered second-generation microphenocrysts. The composition of the latter is similar to that of the second-generation phenocrysts in the tholeiitic rocks (average: $\mathrm{An}_{59}$ mol. \%) except for higher K (Or of 1.4-3.3 mol.\%) and $\mathrm{TiO}_{2}(0.2 \mathrm{wt} . \%)$ in the alkalic rocks. One unusual large xenocryst was encountered in Sample 524-28-3, 70-72 $\mathrm{cm}$ (PI. 5, Fig. 3). The crystal is essentially a perthite, but its composition (Fig. 9) is most unusual in that it consists of a plagioclase $\mathrm{An}_{63}$ phase and a nearly pure $\mathrm{K}$-feldspar phase. In view of the alkalic nature of the rocks with which the crystal is associated, it might be possible to explain the crystal as the result of the alkali metasomatism of a calcic phenocryst from the older tholeiite encountered in the hole. 

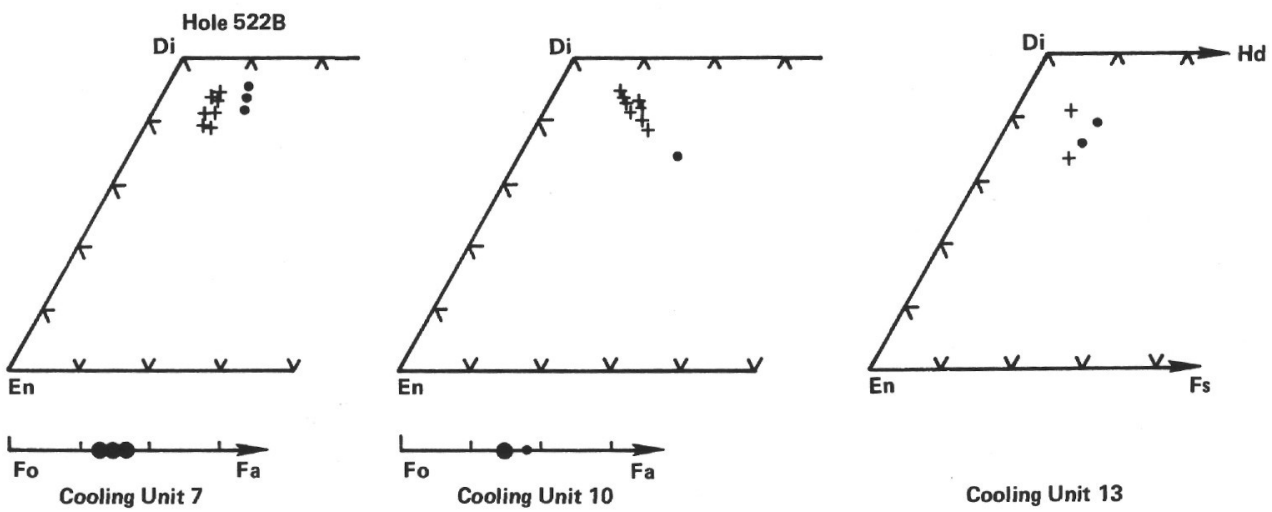

Cooling Unit 13

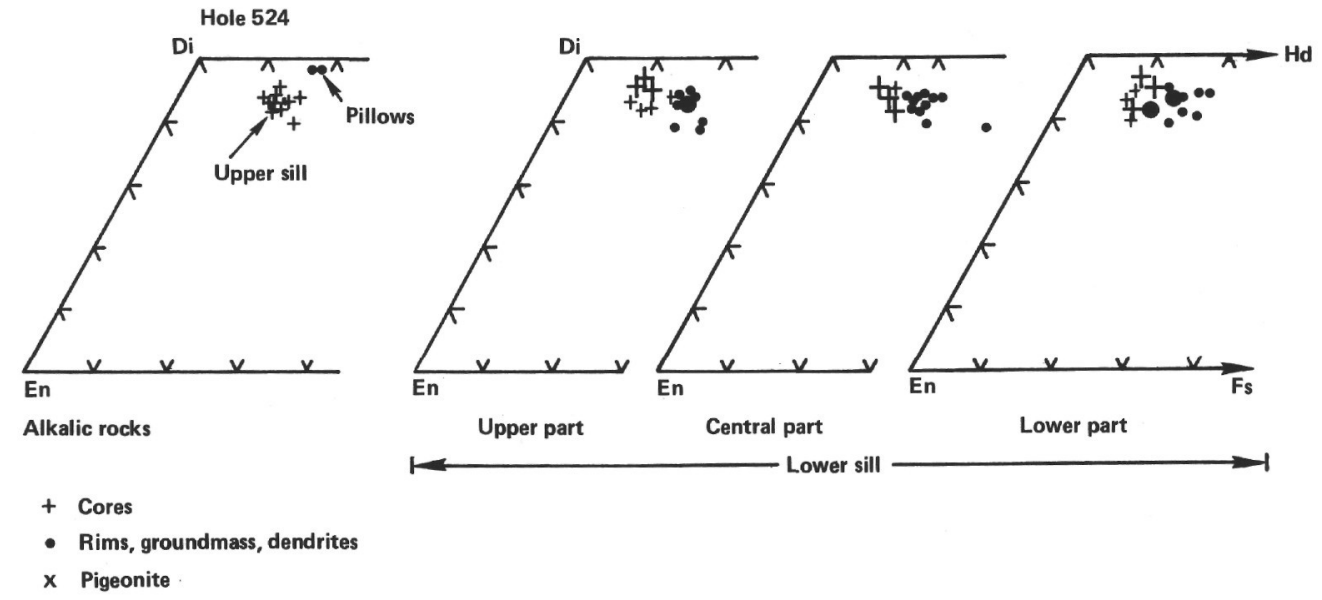

Figure 6. (Continued).

The plagioclase in the alkalic upper sill of Hole 524 is strongly zoned. The cores of the grains are distinctly more sodic (averaging $\mathrm{An}_{45}$ ) and potassic $\left(\mathrm{Or}_{3-4}\right)$ than the plagioclase in the tholeiites. Many plagioclase grains in the coarser rocks are zoned to about $\mathrm{An}_{36}$ and then rather sharply mantled by alkali feldspar. In some instances the zoning is essentially continuous to anorthoclase or even to Na-sanidine (Fig. 9).

\section{Alkali Feldspar}

In the coarser alkalic upper sill of Hole 524, ternary and nearly pure $\mathrm{Na}-\mathrm{K}$ feldspars occur as epitaxial mantles on plagioclase ( $\mathrm{Pl}$. 5, Figs. 4 and 5), as separate groundmass grains, and as fillings of contraction veinlets. Compositionally, these feldspars are mostly $\mathrm{Na}-$ sanidines, although, as noted above, some mantles are zoned from potassium andesine and oligoclase through calcium anorthoclase to anorthoclase (Fig. 9). The axial plane in the alkali feldspars is normal to (010), as would be expected in the compositional values encountered, and $2 \mathrm{~V}_{\mathrm{X}}$ is between 40 and $50^{\circ}$, suggesting that the feldspars have a "structural state" just below that of potassian high albite and sodian high sanidine and that the grains are probably cryptoperthitic (Smith, 1974).

The feldspars in the alkalic rocks of Hole 524 illustrate strong fractional crystallization manifested by extreme compositional zoning and epitaxial alkali feldspar mantles and veinlets. In all of these respects the feldspars resemble those commonly found in continental al- kali diabase sills. The extreme composition of the rim of the phenocryst illustrated for the upper part of the tholeiitic lower sill in Hole 524 (Fig. 7) probably represents the upward migration of volatiles and alkalis in the sill. Such migration would prolong crystallization and promote more extreme fractionation.

\section{Clinopyroxene}

Clinopyroxene occurs as euhedral microphenocrysts in the rocks of Hole 524. It occurs as small sparse grains in the alkalic pillows and sill and as larger and more abundant crystals in the tholeiitic sill. However, the crystallization of clinopyroxene occurs relatively late in the formation of the basalts of Holes 519A, 520, and 522B; it occurs as small and exceedingly sparse microphenocrysts in the rocks of Hole 520 and as small anhedral intergrowths with second-generation plagioclase in the quenched phases of Hole 522B. In all rocks it is found in the various dendritic forms in spherulitic and intersertal phases. The coarser facies of flows and sills contain mostly subophitic grains and smaller subhedral to euhedral intergranular crystals. The thicker flows of Hole 519A (Cooling Units 1, 2, and 4) are notable for the development of relatively large oikocrysts in their coarsest portions.

The compositions of clinopyroxene are illustrated in Figure 6, and the compositions of representative samples are given in Table 5. The clinopyroxene is predom- 
Table 3. Representative microprobe analyses of olivine.

\begin{tabular}{|c|c|c|c|c|c|c|c|}
\hline \multirow{2}{*}{$\begin{array}{l}\text { Cooling Unit } \\
\text { Sample } \\
\text { (interval in } \mathrm{cm} \text { ) }\end{array}$} & \multicolumn{3}{|c|}{1} & \multirow{3}{*}{$\begin{array}{c}2 \\
\text { 519A-8-3, } \\
87-95 \\
\text { Euhedral } \\
\text { intergranular }\end{array}$} & \multirow{3}{*}{$\begin{array}{c}4 \\
519 A-9-4, \\
77-80 \\
\text { Euhedral } \\
\text { intergranular }\end{array}$} & \multirow{3}{*}{$\begin{array}{c}520-30-1 \\
89-95 \\
\text { Skeletal euhedral } \\
\text { microphenocryst }\end{array}$} & \multirow{3}{*}{$\begin{array}{c}520-31-1 \text {, } \\
7-10 \\
\text { Skeletal euhedral } \\
\text { microphenocyst }\end{array}$} \\
\hline & $\begin{array}{l}519 A-7-1 \\
60-66\end{array}$ & $\begin{array}{c}519 A-7-2 \\
46-58\end{array}$ & $\begin{array}{l}519 A-7-2 \\
50-52\end{array}$ & & & & \\
\hline Crystal type & $\begin{array}{l}\text { Tiny euhedral } \\
\text { microphenocryst }\end{array}$ & $\begin{array}{l}\text { Large euhedral } \\
\text { microphenocryst }\end{array}$ & $\begin{array}{l}\text { Large euhedral } \\
\text { microphenocryst }\end{array}$ & & & & \\
\hline $\mathrm{SiO}_{2}$ (wt. \%) & 39.10 & 39.16 & 38.68 & 39.62 & 38.67 & 39.44 & 39.07 \\
\hline $\mathrm{TiO}_{2}$ & - & - & 0.03 & - & - & - & 0.05 \\
\hline $\mathrm{Al}_{2} \mathrm{O}_{3}$ & 0.07 & 0.03 & - & 0.04 & 0.03 & 0.06 & - \\
\hline $\mathrm{Cr}_{2} \mathrm{O}_{3}$ & - & 0.07 & 0.07 & 0.10 & 0.07 & 0.04 & 0.04 \\
\hline $\mathrm{FeO}$ & 12.04 & 15.48 & 15.82 & 12.91 & 19.50 & 16.02 & 17.27 \\
\hline $\mathrm{MnO}$ & 0.23 & 0.23 & 0.27 & 0.20 & 0.29 & 0.26 & 0.25 \\
\hline $\mathrm{MgO}$ & 46.43 & 44.41 & 43.87 & 46.04 & 41.47 & 43.53 & 42.87 \\
\hline $\mathrm{CaO}$ & 0.37 & 0.34 & 0.31 & 0.36 & 0.31 & 0.30 & 0.29 \\
\hline $\mathrm{Na}_{2} \mathrm{O}$ & - & - & 0.03 & 0.03 & - & - & 0.02 \\
\hline$\Sigma$ & 98.24 & 99.72 & 99.08 & 99.30 & 100.34 & 99.65 & 99.86 \\
\hline \multicolumn{8}{|c|}{ Structural formulae ${ }^{a}$} \\
\hline $\mathrm{Si}$ & 0.989 & 0.990 & 0.988 & 0.994 & 0.990 & 0.999 & 0.995 \\
\hline $\mathrm{Al}$ & 0.002 & 0.001 & - & 0.001 & 0.001 & 0.002 & - \\
\hline $\mathrm{Cr}$ & - & 0.001 & 0.001 & 0.002 & 0.001 & 0.001 & 0.001 \\
\hline $\mathrm{Fe}^{+2}$ & 0.255 & 0.327 & 0.338 & 0.271 & 0.418 & 0.339 & 0.368 \\
\hline $\mathrm{Mn}$ & 0.005 & 0.005 & 0.006 & 0.004 & 0.006 & 0.006 & 0.005 \\
\hline Mg & 1.750 & 1.674 & 1.670 & 1.722 & 1.583 & 1.644 & 1.627 \\
\hline $\mathrm{Ca}$ & 0.010 & 0.009 & 0.008 & 0.010 & 0.009 & 0.008 & 0.008 \\
\hline$\Sigma$ & 3.011 & 3.007 & 3.011 & 3.004 & 3.008 & 2.999 & 3.004 \\
\hline Fo & 87.3 & 83.6 & 83.2 & 86.4 & 79.1 & 82.9 & 81.6 \\
\hline $\mathrm{Fa}$ & 12.7 & 16.4 & 16.8 & 13.6 & 20.9 & 17.1 & 18.4 \\
\hline
\end{tabular}

a Structural formulae calculated on the basis of 4 oxygens, omitting traces of $\mathrm{Ti}$ and $\mathrm{Na}$.

Table 4. Representative microprobe analyses of feldspars.

\begin{tabular}{|c|c|c|c|c|c|c|c|c|c|c|c|c|c|}
\hline \multirow{2}{*}{$\begin{array}{l}\text { Cooling Unit } \\
\text { Sample } \\
\text { (interval in cm) }\end{array}$} & \multicolumn{5}{|c|}{1} & \multicolumn{3}{|c|}{2} & \multicolumn{5}{|c|}{4} \\
\hline & \multirow{2}{*}{$\begin{array}{c}\text { 519A-7-1, } \\
4-8 \\
\text { Flow margin }\end{array}$} & \multirow{2}{*}{$\begin{array}{c}\begin{array}{c}519 \mathrm{~A}-7-1, \\
60-66\end{array} \\
\text { Flow margin }\end{array}$} & \multicolumn{3}{|c|}{$\begin{array}{c}519 \mathrm{~A}-7-2, \\
46-58\end{array}$} & \multicolumn{3}{|c|}{$\begin{array}{c}519 \mathrm{~A}-8-3 \\
87-95\end{array}$} & \multicolumn{4}{|c|}{$\begin{array}{c}519 \mathrm{~A}-9-3, \\
48-50\end{array}$} & \multirow[t]{2}{*}{$\begin{array}{l}519 A-9-4 \\
77-80\end{array}$} \\
\hline Location & & & & Fow interi & & & Flow interior & & & & Flow int & & \\
\hline \multirow[b]{2}{*}{ Crystal type } & \multirow{2}{*}{$\begin{array}{l}\text { First-generation } \\
\text { microphenocryst }\end{array}$} & \multirow{2}{*}{$\begin{array}{l}\text { Second-generation } \\
\text { microphenocryst }\end{array}$} & \multicolumn{2}{|c|}{ Coarse zoned grain } & \multirow{2}{*}{$\begin{array}{l}\text { Interstitial } \\
\text { skeletal }\end{array}$} & \multirow{2}{*}{$\begin{array}{l}\text { First-generation } \\
\text { microphenocryst }\end{array}$} & \multirow{2}{*}{$\begin{array}{l}\text { Second-generation } \\
\text { microphenocryst }\end{array}$} & \multirow{2}{*}{$\begin{array}{l}\text { Interstitial } \\
\text { skeletal }\end{array}$} & \multicolumn{2}{|c|}{ Coarse zoned grain } & \multicolumn{2}{|c|}{ Coarse zoned grain } & \multirow{2}{*}{$\begin{array}{c}\text { Interstitia } \\
\text { skeletal }\end{array}$} \\
\hline & & & Core & Rim & & & & & Core & Rim & Core & Rim & \\
\hline $\mathrm{SiO}_{2}(w t . \%)$ & 47.55 & 51.38 & 50.92 & 55.98 & 59.76 & 47.13 & 50.04 & 55.61 & 49.74 & 52.81 & 54.31 & 59.42 & 56.67 \\
\hline $\mathrm{TiO}_{2}$ & - & 0.12 & 0.04 & 0.10 & 0.18 & 0.04 & 0.06 & 0.10 & 0.08 & 0.13 & 0.14 & 0.13 & 0.15 \\
\hline $\mathrm{Al}_{2} \mathrm{O}_{3}$ & 32.43 & 28.76 & 30.26 & 27.18 & 24.38 & 32.83 & 30.26 & 27.59 & 31.17 & 29.19 & 27.98 & 25.11 & 25.78 \\
\hline $\mathrm{Cr}_{2} \mathrm{O}_{3}$ & - & 0.06 & - & - & - & - & - & - & - & - & - & - & - \\
\hline $\mathrm{FeO}$ & 0.42 & 0.96 & 0.50 & 0.87 & 0.99 & 0.43 & 0.60 & 0.79 & 0.55 & 0.69 & 0.80 & 0.74 & 1.06 \\
\hline $\mathrm{MnO}$ & - & 0.09 & 0.04 & - & - & 0.04 & 0.07 & - & - & - & - & - & 0.04 \\
\hline $\mathrm{MgO}$ & 0.18 & 0.51 & 0.44 & 0.14 & 0.07 & 0.23 & 0.29 & 0.11 & 0.24 & 0.18 & 0.12 & 0.04 & 0.10 \\
\hline $\mathrm{CaO}$ & 16.70 & 13.99 & 14.77 & 10.59 & 8.00 & 17.09 & 14.91 & 10.90 & 14.88 & 12.68 & 11.29 & 7.63 & 9.93 \\
\hline $\mathrm{Na}_{2} \mathrm{O}$ & 2.11 & 3.83 & 3.35 & 5.51 & 6.96 & 1.71 & 3.03 & 5.25 & 3.10 & 4.72 & 5.30 & 7.04 & 6.04 \\
\hline $\mathrm{K}_{2} \mathrm{O}$ & 0.01 & 0.05 & 0.03 & 0.04 & 0.07 & 0.01 & 0.02 & 0.04 & 0.01 & 0.02 & 0.03 & 0.06 & 0.05 \\
\hline$\Sigma$ & 99.40 & 99.75 & 100.35 & 100.41 & 100.41 & 99.51 & 99.28 & 100.39 & 99.77 & 100.42 & 99.97 & 100.17 & 99.82 \\
\hline \multicolumn{14}{|l|}{ Structural formulae $\mathrm{e}^{\mathrm{a}}$} \\
\hline $\mathrm{Si}$ & 2.199 & 2.364 & 2.321 & 2.521 & 2.672 & 2.180 & 2.308 & 2.505 & 2.282 & 2.397 & 2.466 & 2.656 & 2.569 \\
\hline & 1.768 & 1.559 & 1.626 & 1.442 & 1.285 & 1.790 & 1.645 & 1.465 & 1.687 & 1.561 & 1.497 & 1.323 & 1.377 \\
\hline $\mathrm{Fe}^{+2}$ & 0.016 & 0.037 & 0.019 & 0.033 & 0.037 & 0.017 & 0.023 & 0.030 & 0.021 & 0.026 & 0.030 & 0.028 & 0.040 \\
\hline $\mathrm{Mg}$ & 0.012 & 0.035 & 0.030 & 0.009 & 0.005 & 0.016 & 0.020 & 0.007 & 0.016 & 0.012 & 0.008 & 0.003 & 0.007 \\
\hline $\mathrm{Ca}$ & 0.827 & 0.690 & 0.721 & 0.511 & 0.383 & 0.847 & 0.737 & 0.526 & 0.732 & 0.617 & 0.549 & 0.365 & 0.482 \\
\hline $\mathrm{Na}$ & 0.189 & 0.342 & 0.296 & 0.481 & 0.603 & 0.153 & 0.271 & 0.458 & 0.276 & 0.415 & 0.467 & 0.610 & 0.531 \\
\hline $\mathbf{K}$ & 0.001 & 0.003 & 0.002 & 0.002 & 0.004 & 0.001 & 0.001 & 0.002 & 0.001 & 0.001 & 0.002 & 0.003 & 0.003 \\
\hline$\Sigma$ & 5.012 & 5.029 & 5.015 & 5.000 & 4.989 & 5.002 & 5.005 & 4.993 & 5.013 & 5.030 & 5.019 & 4.989 & 5.009 \\
\hline An & 81.3 & 66.7 & 70.8 & 51.4 & 38.7 & 84.6 & 73.0 & 53.3 & 72.6 & 59.7 & 54.0 & 37.3 & 47.5 \\
\hline $\mathrm{Ab}$ & 18.6 & 33.0 & 29.0 & 48.4 & 60.9 & 15.3 & 26.9 & 46.5 & 27.4 & 40.2 & 45.8 & 62.3 & 52.2 \\
\hline Or & 0.1 & 0.3 & 0.2 & 0.2 & 0.4 & 0.1 & 0.1 & 0.2 & 0.05 & 0.1 & 0.2 & 0.4 & 0.3 \\
\hline \multicolumn{14}{|l|}{$\mathrm{CaO}(\mathrm{mol} . \%):$} \\
\hline Measure or average $b$ & 89.7 & 80.0 & 82.9 & 67.9 & 55.8 & 91.6 & 84.4 & 69.5 & 84.1 & 74.8 & 70.1 & 54.4 & $\begin{array}{c}64.4 \\
89.38 .4\end{array}$ \\
\hline \multicolumn{14}{|l|}{$\mathrm{Na}_{2} \mathrm{O}(\mathrm{mol} . \%)$} \\
\hline Averageb & 10.3 & 19.8 & 17.0 & 32.0 & 43.9 & 8.3 & 15.5 & 30.3 & 15.9 & 25.2 & 29.8 & 45.4 & 35.4 \\
\hline \multirow{2}{*}{\multicolumn{14}{|c|}{$\mathrm{K}_{2} \mathrm{O}(\mathrm{mol} . \%):$}} \\
\hline & & & & & & & & & & & & & \\
\hline Range & $0.0-0.13$ & $0.1-0.2$ & 0.1 & 0.1 & $\begin{array}{l}0.3 \\
0.1-0.3\end{array}$ & 0.03 & $\begin{array}{c}0.1 \\
0.0-0.1\end{array}$ & $\begin{array}{l}0.2 \\
0.1-0.3\end{array}$ & 0.03 & 0.1 & 0.1 & 0.2 & $0.0-0.6$ \\
\hline
\end{tabular}

a Structural formulae calculated on the basis of 8 oxygens, omitting traces of $\mathrm{Ti}, \mathrm{Cr}$, and $\mathrm{Mn}$.

b Quantity is an average if range is given. 
Table 3. (Continued).

\begin{tabular}{|c|c|c|c|c|c|c|}
\hline \multirow{3}{*}{$\begin{array}{c}520-31-1, \\
16-22 \\
\text { Skeletal euhedral } \\
\text { microphenocryst }\end{array}$} & \multicolumn{2}{|c|}{3} & \multicolumn{2}{|c|}{7} & \multirow{3}{*}{$\begin{array}{c}10 \\
522 \mathrm{~B}-5-2, \\
126-130 \\
\text { Euhedral } \\
\text { intergranular }\end{array}$} & \multirow{3}{*}{$\begin{array}{c}\text { Upper sill } \\
524-29-1, \\
102-105 \\
\text { Small euhedral } \\
\text { microphenocrys }\end{array}$} \\
\hline & \multicolumn{2}{|c|}{$\begin{array}{c}522 \mathrm{~B}-3-3 \\
138-142\end{array}$} & \multicolumn{2}{|c|}{$\begin{array}{l}522 \mathrm{~B}-4-2 \\
68-71\end{array}$} & & \\
\hline & $\begin{array}{l}\text { Small euhedral } \\
\text { microphenocryst }\end{array}$ & $\begin{array}{c}\text { Small euhedral } \\
\text { microphenocryst }\end{array}$ & $\begin{array}{l}\text { Medium euhedral } \\
\text { microphenocryst }\end{array}$ & $\begin{array}{l}\text { Medium euhedral } \\
\text { microphenocryst }\end{array}$ & & \\
\hline 39.13 & 39.68 & 39.73 & 40.29 & 40.05 & 39.64 & 40.10 \\
\hline 0.05 & - & 0.04 & - & - & - & - \\
\hline- & 0.07 & 0.07 & - & - & - & - \\
\hline 0.08 & - & 0.07 & 0.06 & 0.08 & - & - \\
\hline 15.95 & 13.63 & 13.05 & 13.77 & 13.27 & 14.41 & 13.94 \\
\hline 0.27 & 0.27 & 0.26 & 0.26 & 0.23 & 0.16 & 0.17 \\
\hline 43.76 & 45.50 & 45.28 & 45.73 & 46.35 & 46.17 & 45.51 \\
\hline 0.33 & 0.34 & 0.35 & 0.32 & 0.30 & - & 0.30 \\
\hline 0.03 & - & - & - & - & - & - \\
\hline 99.60 & 99.49 & 98.85 & 100.46 & 100.28 & 100.71 & 100.02 \\
\hline 0.994 & 0.996 & 1.002 & 1.002 & 0.996 & 0.989 & 1.002 \\
\hline- & 0.002 & 0.002 & - & - & - & - \\
\hline 0.002 & - & 0.001 & 0.001 & 0.002 & - & - \\
\hline 0.339 & 0.286 & 0.275 & 0.286 & 0.276 & 0.301 & 0.291 \\
\hline 0.006 & 0.006 & 0.006 & 0.005 & 0.005 & 0.003 & 0.004 \\
\hline 1.656 & 1.703 & 1.701 & 1.695 & 1.718 & 1.717 & 1.694 \\
\hline 0.009 & 0.009 & 0.009 & 0.009 & 0.008 & - & 0.008 \\
\hline 3.006 & 3.002 & 2.996 & 2.998 & 3.005 & 3.010 & 2.999 \\
\hline 83.0 & 85.6 & 86.1 & 85.5 & 86.1 & 85.1 & 85.3 \\
\hline 17.0 & 14.4 & 13.9 & 14.5 & 13.9 & 14.9 & 14.7 \\
\hline
\end{tabular}

Table 4. (Continued).

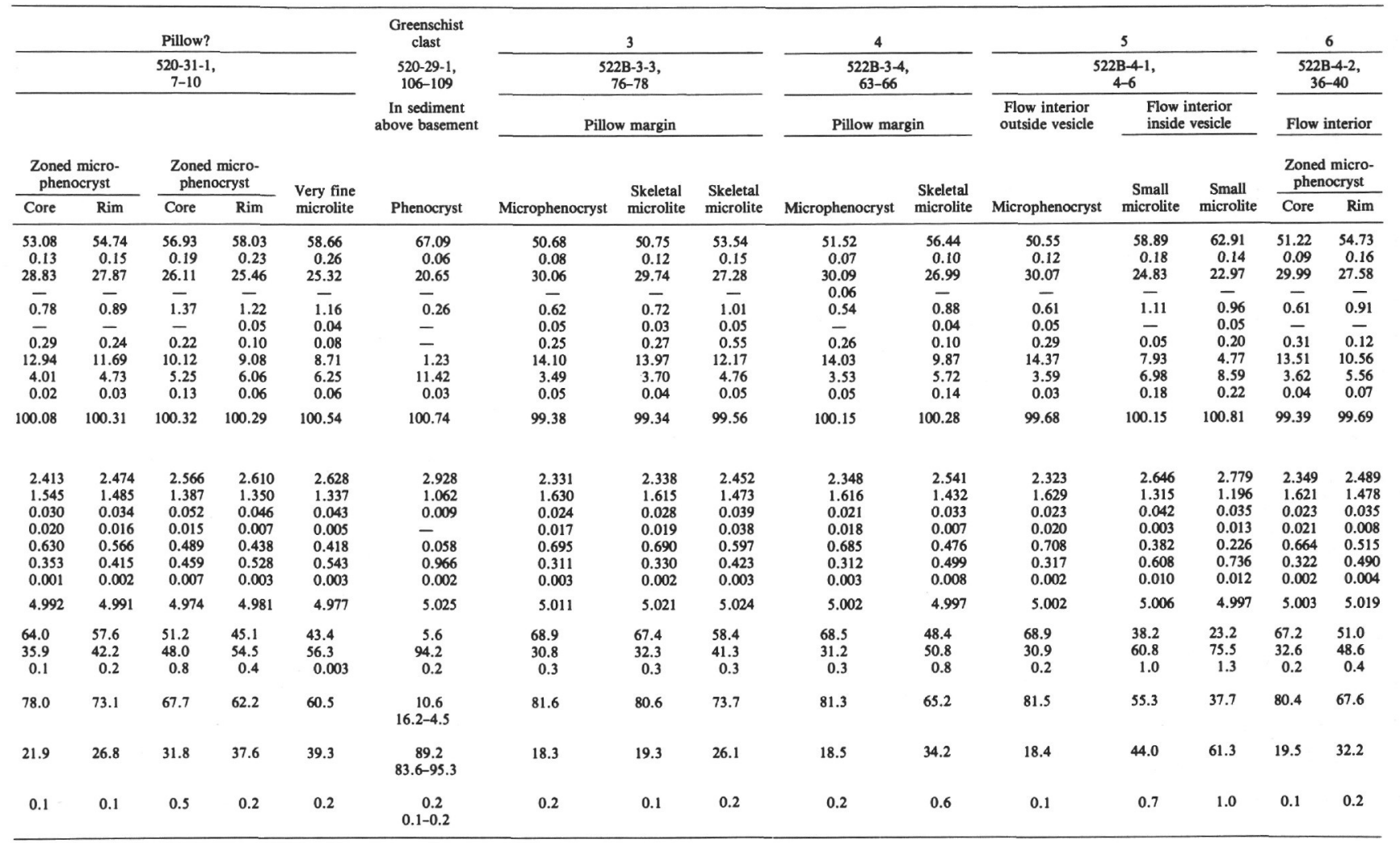


Table 4. (Continued).

\begin{tabular}{|c|c|c|c|c|c|c|c|c|c|c|c|c|c|c|}
\hline \multirow{2}{*}{$\begin{array}{l}\text { Cooling Unit } \\
\text { Sample } \\
\text { (interval in } \mathrm{cm} \text { ) }\end{array}$} & \multicolumn{4}{|c|}{7} & & \multicolumn{3}{|c|}{10} & \multicolumn{4}{|c|}{13} & \multicolumn{2}{|c|}{ Pillow } \\
\hline & & \multicolumn{3}{|c|}{$\begin{array}{c}522 \mathrm{~B}-4-2 \\
68-71\end{array}$} & $\begin{array}{c}522 \mathrm{~B}-4-2 \\
93-95\end{array}$ & \multicolumn{3}{|c|}{$\begin{array}{c}522 \mathrm{~B}-5-2 \\
126-130\end{array}$} & \multicolumn{4}{|c|}{$\begin{array}{c}522 \mathrm{~B}-6-1 \\
70-74\end{array}$} & \multicolumn{2}{|c|}{$\begin{array}{c}524-28-3, \\
70-72\end{array}$} \\
\hline \multirow{3}{*}{$\begin{array}{l}\text { Location } \\
\text { Crystal type }\end{array}$} & & \multicolumn{3}{|c|}{ Flow margin } & Flow interior & \multicolumn{3}{|c|}{ Flow interior } & \multicolumn{4}{|c|}{ Flow interior } & \multicolumn{2}{|c|}{ Pillow interior } \\
\hline & $\begin{array}{l}\text { First-ge } \\
\text { microph }\end{array}$ & $\begin{array}{l}\text { eration } \\
\text { nocryst }\end{array}$ & \multirow{2}{*}{$\begin{array}{l}\text { Second-generation } \\
\text { microphenocryst }\end{array}$} & \multirow{2}{*}{$\begin{array}{c}\text { Skeletal } \\
\text { microlite }\end{array}$} & \multirow{2}{*}{$\begin{array}{l}\text { First-generation } \\
\text { microphenocryst }\end{array}$} & \multicolumn{2}{|c|}{$\begin{array}{l}\text { Zoned micro- } \\
\text { phenocryst }\end{array}$} & \multirow{2}{*}{$\begin{array}{l}\text { Interstitial } \\
\text { microlite }\end{array}$} & \multicolumn{2}{|c|}{$\begin{array}{l}\text { 1st generation } \\
\text { zoned micro- } \\
\text { phenocryst }\end{array}$} & \multicolumn{2}{|c|}{$\begin{array}{c}\text { 2nd generation(?) } \\
\text { zoned micro- } \\
\text { phenocryst }\end{array}$} & \multicolumn{2}{|c|}{ Large xenocryst } \\
\hline & Core & Rim & & & & Core & Rim & & Core & Rim & Core & Rim & An-rich phase & Or-rich phase \\
\hline $\mathrm{SiO}_{2}$ (wt.\%) & 48.59 & 50.37 & 50.73 & 51.77 & 47.59 & 50.91 & 54.83 & 55.88 & 49.04 & 53.16 & 51.57 & 52.54 & 52.83 & 66.52 \\
\hline $\mathrm{TiO}_{2}$ & 0.09 & 0.10 & 0.11 & 0.11 & $0 ; 07$ & 0.07 & 0.10 & 0.15 & - & 0.10 & 0.09 & 0.10 & 0.15 & 0.06 \\
\hline $\mathrm{Al}_{2} \mathrm{O}_{3}$ & 32.01 & 30.51 & 30.39 & 29.45 & 31.75 & 29.94 & 27.50 & 27.42 & 31.96 & 28.53 & 31.02 & 29.42 & 29.58 & 18.59 \\
\hline $\mathrm{Cr}_{2} \mathrm{O}_{3}$ & - & - & - & - & - & - & 0.04 & - & - & - & - & - & - & - \\
\hline $\mathrm{FeO}$ & 0.48 & 0.57 & 0.57 & 0.75 & 0.49 & 0.45 & 0.74 & 1.17 & 0.39 & 0.85 & 0.65 & 0.85 & 0.62 & 0.11 \\
\hline $\mathrm{MnO}$ & - & - & - & - & 0.04 & 0.04 & 0.04 & - & - & - & 0.04 & 0.04 & - & - \\
\hline $\mathrm{MgO}$ & 0.30 & 0.34 & 0.37 & 0.28 & 0.22 & 0.26 & 0.23 & 0.17 & 0.20 & 0.21 & 0.27 & 0.25 & 0.09 & - \\
\hline $\mathrm{CaO}$ & 15.96 & 14.62 & 14.22 & 13.70 & 15.99 & 14.98 & 12.08 & 10.60 & 16.29 & 12.50 & 14.77 & 13.30 & 12.54 & 0.04 \\
\hline $\mathrm{Na}_{2} \mathrm{O}$ & 2.55 & 3.26 & 3.51 & 3.97 & 2.49 & 3.26 & $\begin{array}{r}4.00 \\
4.78\end{array}$ & 5.12 & 2.25 & 4.35 & 3.29 & 4.00 & 3.91 & 0.10 \\
\hline $\mathrm{K}_{2} \mathrm{O}$ & 0.02 & 0.03 & 0.03 & 0.03 & 0.02 & 0.04 & 0.07 & 0.09 & 0.03 & 0.06 & 0.02 & 0.03 & 0.44 & 15.87 \\
\hline$\Sigma$ & 100.00 & 99.80 & 99.93 & 100.06 & 98.66 & 99.95 & 100.41 & 100.60 & 100.16 & 99.76 & 101.72 & 100.53 & 100.16 & 101.29 \\
\hline \multicolumn{15}{|l|}{ Structural formulae $\mathrm{a}^{\mathrm{a}}$} \\
\hline $\mathrm{Si}$ & 2.231 & 2.309 & 2.321 & 2.364 & 2.219 & 2.331 & 2.480 & 2.515 & 2.244 & 2.424 & 2.318 & 2.384 & 2.399 & 3.019 \\
\hline $\mathrm{Al}$ & 1.733 & 1.648 & 1.639 & 1.585 & 1.744 & 1.615 & 1.466 & 1.452 & 1.723 & 1.533 & 1.644 & 1.573 & 1.583 & 0.994 \\
\hline $\mathrm{Fe}^{+2}$ & 0.018 & 0.022 & 0.022 & 0.029 & 0.019 & 0.017 & 0.028 & 0.044 & 0.015 & 0.032 & 0.024 & 0.032 & 0.025 & 0.004 \\
\hline $\mathrm{Mg}$ & 0.021 & 0.023 & 0.025 & 0.019 & 0.015 & 0.018 & 0.016 & 0.011 & 0.014 & 0.014 & 0.018 & 0.016 & 0.006 & - \\
\hline $\mathrm{Ca}$ & 0.785 & 0.718 & 0.697 & 0.670 & 0.799 & 0.735 & 0.585 & 0.510 & 0.799 & 0.611 & 0.711 & 0.647 & 0.610 & 0.002 \\
\hline $\mathrm{Na}$ & 0.227 & 0.290 & 0.311 & 0.351 & 0.225 & 0.289 & 0.419 & 0.446 & 0.200 & 0.385 & 0.287 & 0.352 & 0.344 & 0.009 \\
\hline $\mathbf{K}$ & 0.001 & 0.002 & 0.002 & 0.002 & 0.001 & 0.002 & 0.004 & 0.005 & 0.002 & 0.003 & 0.001 & 0.002 & 0.025 & 0.919 \\
\hline$\Sigma$ & 5.016 & 5.012 & 5.016 & 5.020 & 5.022 & 5.007 & 4.998 & 4.984 & 4.995 & 5.003 & 5.004 & 5.006 & 4.994 & 4.947 \\
\hline An & 77.5 & 71.1 & 69.0 & 65.5 & 77.9 & 71.6 & 58.0 & 53.1 & 79.9 & 61.1 & 71.2 & 64.6 & 62.3 & 0.2 \\
\hline $\mathrm{Ab}$ & 22.4 & 28.7 & 30.8 & 34.3 & 22.0 & 28.2 & 41.6 & 46.4 & 20.0 & 38.5 & 28.7 & 35.2 & 35.1 & 0.9 \\
\hline \multirow{2}{*}{\multicolumn{15}{|c|}{$\mathrm{CaO}(\mathrm{mol} . \%):$}} \\
\hline & & & & & & & & & & & & & & \\
\hline $\begin{array}{l}\text { Measure or average } \\
\text { Range }\end{array}$ & 87.3 & 83.1 & $\begin{array}{c}81.7 \\
84.0-71.0\end{array}$ & $\begin{array}{c}79.1 \\
82.9-76.4\end{array}$ & $\begin{array}{c}87.6 \\
89.8-84.6\end{array}$ & 83.5 & 73.4 & $\begin{array}{c}69.3 \\
77.8-63.4\end{array}$ & 88.8 & 75.9 & 83.2 & 78.5 & 76.7 & 0.4 \\
\hline $\mathrm{Na}_{2} \mathrm{O}(\mathrm{mol}, \%)$ & & & & & & & & & & & & & & \\
\hline $\begin{array}{l}\text { Average } \\
\text { Range }\end{array}$ & 12.6 & 16.8 & $\begin{array}{c}18.2 \\
15.9-28.3\end{array}$ & $\begin{array}{c}20.8 \\
17.0-23.4\end{array}$ & $\begin{array}{c}12.3 \\
10.2-14.6\end{array}$ & 16.4 & 26.3 & $\begin{array}{c}30.3 \\
22.0-36.1\end{array}$ & 11.1 & 23.9 & 16.8 & 21.4 & 21.7 & 0.9 \\
\hline $\begin{array}{c}\mathrm{K}_{2} \mathrm{O} \text { (mol. \%) } \\
\text { Average } \\
\text { Range }\end{array}$ & 0.1 & 0.1 & $\begin{array}{c}0.1 \\
0.1-0.6\end{array}$ & $\begin{array}{c}0.1 \\
0.1-0.3\end{array}$ & $\begin{array}{c}0.1 \\
0.0-0.9\end{array}$ & 0.1 & 0.3 & $\begin{array}{c}0.4 \\
0.2-0.5\end{array}$ & 0.1 & 0.2 & 0.1 & 0.1 & 1.6 & 98.7 \\
\hline
\end{tabular}

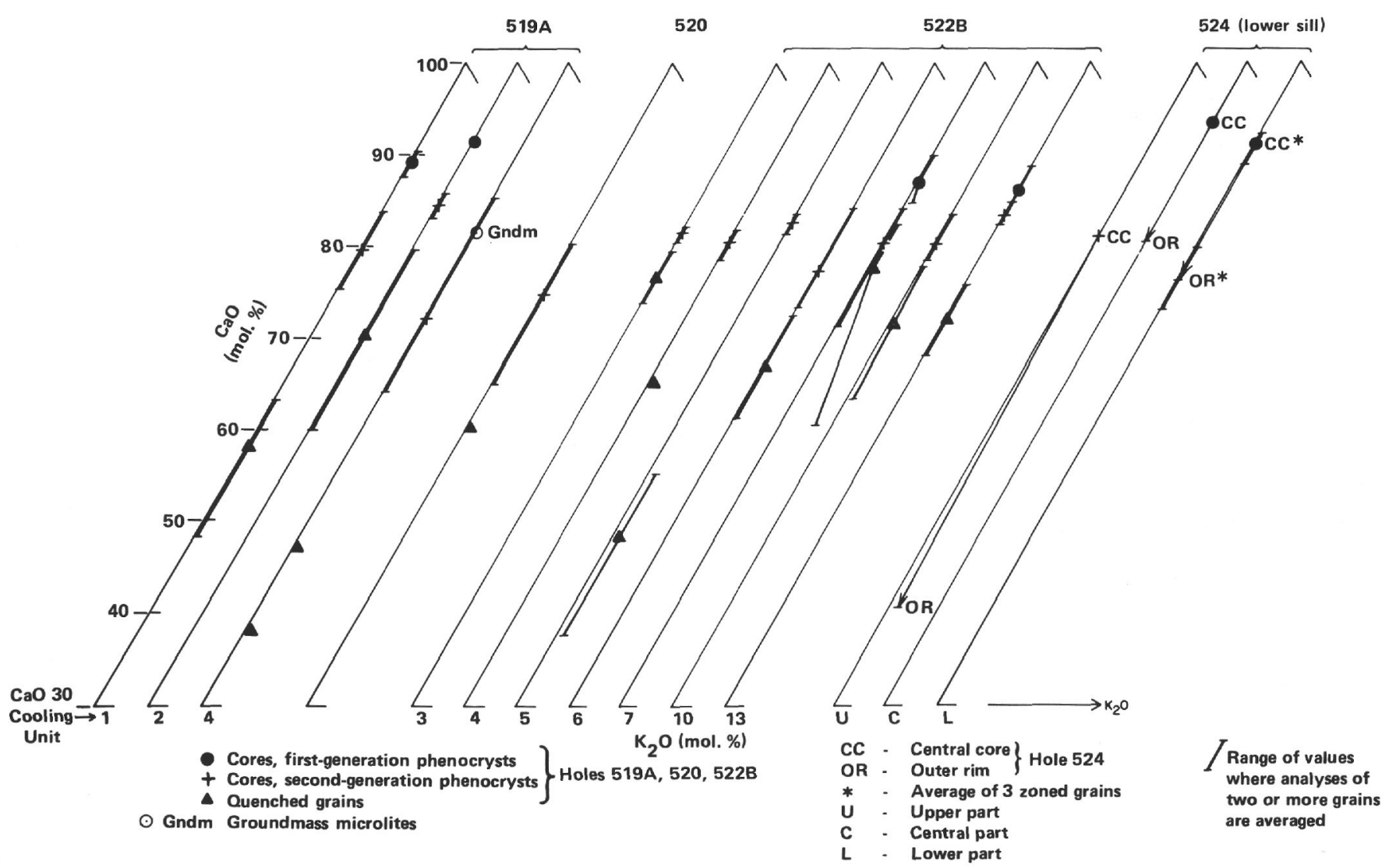

Figure 7. Plagioclase compositions of tholeiitic rocks of Holes 519A, 520, 522B, and 524. Plots show average compositions and ranges for the various types of crystals distinguished petrographically. Plots are for $\mathrm{CaO}, \mathrm{Na}_{2} \mathrm{O}$, and $\mathrm{K}_{2} \mathrm{O}(\mathrm{mol} . \%)$. 
Table 4. (Continued).

\begin{tabular}{|c|c|c|c|c|c|c|c|c|c|c|c|c|c|c|c|}
\hline \multirow{2}{*}{\multicolumn{2}{|c|}{$\begin{array}{c}\text { Pillow } \\
524-28-3, \\
93-97\end{array}$}} & \multicolumn{5}{|c|}{ Upper sill } & & & \multicolumn{7}{|c|}{ Lower sill } \\
\hline & & & & $\begin{array}{c}524-31-1 \\
108-11\end{array}$ & & & $\begin{array}{l}\text { 524-29-1, } \\
102-105\end{array}$ & $\begin{array}{c}524-30-2, \\
72-76\end{array}$ & \multirow{2}{*}{\multicolumn{2}{|c|}{$\begin{array}{c}\begin{array}{c}524-33-1, \\
8-11\end{array} \\
\begin{array}{c}\text { Sill interior, } \\
\text { upper part }\end{array}\end{array}$}} & \multicolumn{2}{|c|}{$\begin{array}{l}524-33-1, \\
112-116\end{array}$} & \multicolumn{3}{|c|}{$\begin{array}{c}524-34-2 \\
18-21\end{array}$} \\
\hline \multicolumn{2}{|c|}{ Pillow interior } & \multicolumn{5}{|c|}{ Sill interior } & \multicolumn{2}{|c|}{ Sill margin } & & & \multicolumn{2}{|c|}{$\begin{array}{l}\text { Sill interior, } \\
\text { central part }\end{array}$} & \multicolumn{3}{|c|}{ Sill interior, lower part } \\
\hline \multirow[b]{2}{*}{ Microlite } & \multirow[b]{2}{*}{ Microlite } & \multicolumn{5}{|c|}{ Mantled grain } & & & \multicolumn{2}{|c|}{$\begin{array}{c}\text { Zoned } \\
\text { phenocryst }\end{array}$} & \multicolumn{2}{|c|}{ Zoned phenocryst } & \multicolumn{3}{|c|}{ Zoned phenocryst } \\
\hline & & Inner core & Outer core & Inner mantle & Outer mantle & Outer mantle rim & \multicolumn{2}{|c|}{ Contraction veinlet } & Core & Rim & Core & $\operatorname{Rim}$ & Inner core & Outer core & Rim \\
\hline 53.37 & 55.21 & 56.43 & 59.26 & 66.62 & 66.57 & 67.56 & 65.24 & 65.73 & 50.95 & 62.15 & 46.49 & 52.18 & 47.38 & 50.87 & 53.64 \\
\hline 0.22 & 0.19 & 0.14 & 0.11 & 0.06 & 0.06 & 0.05 & 0.13 & 0.04 & 0.12 & 0.10 & 0.06 & 0.12 & 0.08 & 0.10 & 0.12 \\
\hline 27.81 & 26.69 & 26.96 & 25.67 & 19.35 & 18.67 & 18.81 & 19.19 & 19.25 & 29.22 & 22.91 & 33.74 & 29.73 & 32.55 & 29.77 & 27.90 \\
\hline- & 0.04 & - & - & - & - & - & - & - & - & - & - & - & - & - & - \\
\hline 0.92 & 0.81 & 0.47 & 0.42 & 0.22 & 0.30 & 0.33 & 0.35 & 0.18 & 0.76 & 0.55 & 0.45 & 0.71 & 0.56 & 0.64 & 0.92 \\
\hline 0.04 & - & - & - & - & - & - & - & 0.03 & - & - & 0.05 & 0.05 & 0.04 & 0.04 & 0.04 \\
\hline 0.15 & 0.13 & - & - & - & - & - & - & - & 0.14 & - & 0.14 & 0.20 & 0.13 & 0.13 & 0.08 \\
\hline 12.52 & 10.98 & 9.35 & 7.54 & 0.88 & 0.47 & 0.46 & 1.16 & 0.05 & 13.87 & 5.36 & 17.97 & 13.93 & 17.00 & 14.24 & 11.88 \\
\hline 4.23 & 4.98 & 5.66 & 6.59 & 5.34 & 5.34 & 5.81 & 5.50 & 0.30 & 3.85 & 8.40 & 1.41 & 3.69 & 1.92 & 3.52 & 4.81 \\
\hline 0.48 & 0.66 & 0.66 & 0.96 & 8.20 & 8.59 & 8.17 & 8.36 & 15.38 & 0.05 & 0.27 & 0.01 & 0.06 & 0.02 & 0.04 & 0.08 \\
\hline 99.74 & 99.69 & 99.67 & 100.55 & 100.67 & 100.00 & 101.19 & 99.93 & 100.96 & 98.96 & 99.74 & 100.32 & 100.67 & 99.68 & 99.35 & 99.47 \\
\hline 2.444 & 2.517 & 2.553 & 2.644 & 2.978 & 2.999 & 3.003 & 2.955 & 2.991 & 2.356 & 2.773 & 2.139 & 2.367 & 2.190 & 2.342 & 2.453 \\
\hline 1.501 & 1.434 & 1.437 & 1.350 & 1.019 & 0.991 & 0.985 & 1.025 & $\begin{array}{l}1.032 \\
\end{array}$ & $\begin{array}{l}1.592 \\
\end{array}$ & 1.205 & 1.830 & 1.590 & 1.773 & 1.615 & 1.504 \\
\hline 0.035 & 0.031 & 0.018 & 0.016 & 0.008 & 0.011 & 0.012 & 0.013 & 0.007 & 0.029 & 0.021 & 0.017 & 0.027 & 0.022 & 0.025 & 0.035 \\
\hline 0.010 & 0.008 & - & - & - & - & - & - & - & 0.010 & - & 0.010 & 0.014 & 0.009 & 0.009 & 0.005 \\
\hline 0.614 & 0.536 & 0.453 & 0.360 & 0.042 & 0.023 & 0.022 & 0.056 & 0.002 & 0.687 & 0.256 & 0.886 & 0.677 & 0.842 & 0.702 & 0.582 \\
\hline 0.376 & 0.440 & 0.496 & 0.570 & 0.463 & 0.466 & 0.501 & 0.483 & 0.026 & 0.345 & 0.727 & 0.126 & 0.325 & 0.172 & 0.314 & 0.426 \\
\hline 0.028 & 0.038 & 0.038 & 0.055 & 0.468 & 0.494 & 0.463 & 0.483 & 0.893 & 0.003 & 0.015 & 0.001 & 0.003 & 0.001 & 0.002 & 0.005 \\
\hline 5.008 & 5.005 & 4.996 & 4.994 & 4.978 & 4.985 & 4.986 & 5.016 & 4.952 & 5.002 & 4.996 & 5.009 & 5.002 & 5.010 & 5.009 & 5.011 \\
\hline 60.3 & 52.8 & 45.9 & 36.6 & 4.3 & 2.3 & 2.2 & 5.5 & 0.2 & 66.4 & 25.7 & 87.5 & 67.4 & 82.9 & 69.0 & 57.4 \\
\hline 36.9 & 43.4 & 50.3 & 57.9 & 47.6 & 47.5 & 50.8 & 47.2 & $\begin{array}{l}0.2 \\
2.9\end{array}$ & $\begin{array}{l}30.4 \\
33.3\end{array}$ & 72.8 & 12.4 & 32.3 & 17.0 & 30.8 & 42.1 \\
\hline 2.8 & 3.8 & 3.8 & 5.5 & 48.1 & 50.2 & 47.0 & 47.3 & 96.9 & 0.3 & 1.5 & 0.1 & 0.3 & 0.1 & 0.2 & 0.5 \\
\hline 75.3 & 69.1 & 62.9 & 53.6 & 8.3 & 4.5 & 4.3 & $\begin{array}{c}10.4 \\
21.7-3.9\end{array}$ & 0.5 & 79.8 & 40.9 & 93.3 & 80.5 & 90.7 & 81.6 & 73.0 \\
\hline 23.0 & 28.4 & 34.5 & 42.3 & 45.7 & 46.4 & 49.7 & $\begin{array}{c}44.8 \\
43.2-46.0\end{array}$ & 2.9 & 20.0 & 57.9 & 6.6 & 19.3 & 9.2 & 18.3 & 26.7 \\
\hline 1.7 & 2.5 & 2.6 & 4.1 & 46.1 & 49.1 & 46.0 & $\begin{array}{c}44.8 \\
35.1-50.1\end{array}$ & 96.6 & 0.2 & 1.2 & 0.03 & 0.2 & 0.1 & 0.1 & 0.3 \\
\hline
\end{tabular}
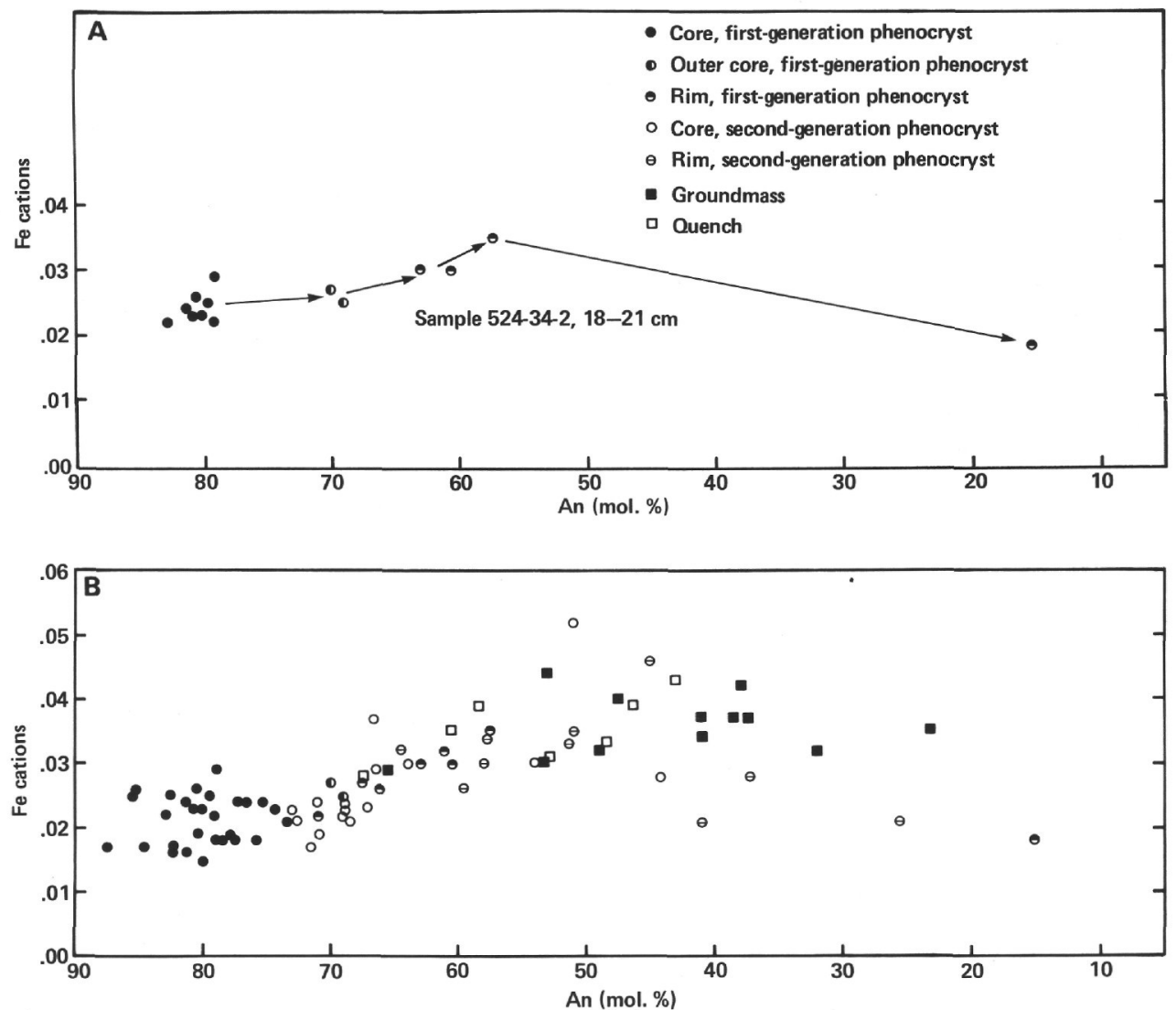

Figure 8. Fe cations on the basis of 8 oxygens versus An in zoned plagioclase from tholeiitic rocks. A. Plot of single grain from core to rim. Sample 524-34-2, 18-21 cm, from the lower sill, lower part. B. Composite of values from all holes. 
M. F. CARMAN, V. J. DIETRICH, J. SOMMERAUER

Table 5. Representative microprobe analyses of clinopyroxenes.

\begin{tabular}{|c|c|c|c|c|c|c|c|c|c|c|c|c|c|c|c|c|c|}
\hline \multirow{3}{*}{$\begin{array}{l}\text { Cooling Unit } \\
\text { Sample } \\
\text { (interval in cm) } \\
\text { Location }\end{array}$} & \multicolumn{9}{|c|}{1} & \multirow{2}{*}{\multicolumn{2}{|c|}{$\begin{array}{c}2 \\
519 \mathrm{~A}-8-3 \\
87-95\end{array}$}} & \multicolumn{6}{|c|}{4} \\
\hline & \multicolumn{2}{|c|}{$\begin{array}{c}519 A-7-1, \\
60-66\end{array}$} & $\begin{array}{c}519 \mathrm{~A}-7-2 \\
46-58\end{array}$ & \multicolumn{4}{|c|}{$\begin{array}{c}519 \mathrm{~A}-7-2 \\
50-52\end{array}$} & \multicolumn{2}{|c|}{$\begin{array}{c}519 \mathrm{~A}-7-2 \\
46-58\end{array}$} & & & \multicolumn{6}{|c|}{$\begin{array}{c}519 \mathrm{~A}-9-3 \\
48-50\end{array}$} \\
\hline & \multicolumn{2}{|c|}{ Chilled flow margin } & & \multicolumn{6}{|c|}{ Flow interior } & \multicolumn{2}{|c|}{ Flow interior } & \multicolumn{6}{|c|}{ Flow interior } \\
\hline & \multirow{2}{*}{$\begin{array}{l}\text { Near average } \\
\text { fine } \\
\text { dendritic }\end{array}$} & \multirow[b]{2}{*}{$\begin{array}{l}\text { Coarse } \\
\text { dendritic }\end{array}$} & \multirow[b]{2}{*}{$\begin{array}{l}\text { En-rich } \\
\text { euhedral }\end{array}$} & \multicolumn{3}{|c|}{$\begin{array}{l}\text { Ophitic zoned } \\
\text { grain }\end{array}$} & \multirow{2}{*}{$\begin{array}{l}\text { Near average } \\
\text { pinkish } \\
\text { groundmass }\end{array}$} & \multirow{2}{*}{$\begin{array}{c}\text { Wo-rich } \\
\text { En-poor } \\
\text { groundmass }\end{array}$} & \multirow[b]{2}{*}{$\begin{array}{l}\text { Subcalcic } \\
\text { groundmass }\end{array}$} & \multirow[b]{2}{*}{ Subophitic } & \multirow[b]{2}{*}{$\begin{array}{c}\text { Inter- } \\
\text { granular }\end{array}$} & \multicolumn{3}{|c|}{$\begin{array}{l}\text { Euhedral zoned grain } \\
\text { "equilibrium trend" }\end{array}$} & \multicolumn{3}{|c|}{$\begin{array}{l}\text { Ophitic zoned grain } \\
\text { "quench trend" }\end{array}$} \\
\hline Crystal type & & & & $\begin{array}{l}\text { Inner } \\
\text { core }\end{array}$ & $\begin{array}{l}\text { Outer } \\
\text { core }\end{array}$ & Rim & & & & & & $\begin{array}{l}\text { Inner } \\
\text { core }\end{array}$ & $\begin{array}{l}\text { Outer } \\
\text { core }\end{array}$ & Rim & $\begin{array}{l}\text { Inner } \\
\text { core }\end{array}$ & $\begin{array}{l}\text { Outer } \\
\text { core }\end{array}$ & Rim \\
\hline $\mathrm{SiO}_{2}$ (wt. \%) & 45.99 & 48.45 & 53.42 & 52.23 & 51.23 & 49.72 & 49.67 & 49.99 & 50.92 & 49.90 & 51.36 & 50.66 & 51.65 & 51.02 & 51.28 & 50.86 & 51.52 \\
\hline $\mathrm{TiO}_{2}$ & 2.60 & 1.99 & 0.46 & 0.84 & 0.99 & 1.57 & 1.70 & 1.50 & 1.16 & 1.44 & 0.91 & 1.04 & 0.92 & 1.04 & 0.80 & 1.10 & 0.95 \\
\hline $\mathrm{Al}_{2} \mathrm{O}_{3}$ & 5.16 & 9.07 & 1.50 & 3.15 & 2.26 & 2.75 & 2.48 & 2.20 & 1.97 & 4.74 & 2.64 & 4.23 & 2.36 & 1.58 & 3.24 & 2.53 & 1.81 \\
\hline $\mathrm{Cr}_{2} \mathrm{O}_{3}$ & 0.31 & 0.13 & 0.23 & 0.40 & - & - & 2.40 & 0.06 & 0.05 & 0.25 & 0.06 & 0.58 & - & - & 0.26 & - & - \\
\hline $\mathrm{FeO}$ & 12.30 & 11.82 & 6.74 & 6.15 & 10.97 & $13 . \overline{74}$ & 14.52 & 14.65 & 18.59 & 7.33 & 9.85 & 6.88 & 11.07 & 14.88 & 7.28 & 10.57 & 14.28 \\
\hline $\mathrm{MnO}$ & 0.23 & 0.28 & 0.20 & 0.17 & 0.36 & 0.32 & 0.34 & 0.36 & 0.44 & 0.20 & 0.30 & 0.16 & 0.31 & 0.44 & 0.18 & 0.28 & 0.34 \\
\hline $\mathrm{MgO}$ & 10.35 & 8.74 & 18.97 & 16.48 & 16.16 & 13.01 & 13.25 & 11.51 & 15.60 & 15.19 & 15.90 & 16.34 & 16.45 & 13.27 & 16.25 & 15.59 & 17.11 \\
\hline $\mathrm{CaO}$ & 20.99 & 18.08 & 18.27 & 20.67 & 16.92 & 18.03 & 17.41 & 20.05 & 9.95 & 19.99 & 18.13 & 19.75 & 16.80 & 17.47 & 20.08 & 18.36 & 13.25 \\
\hline $\mathrm{Na}_{2} \mathrm{O}$ & 0.37 & 0.76 & 0.23 & 0.31 & 0.32 & 0.42 & 0.37 & 0.35 & 0.27 & 0.32 & 0.29 & 0.34 & 0.29 & 0.34 & 0.30 & 0.33 & 0.24 \\
\hline $\mathrm{K}_{2} \mathrm{O}$ & 0.01 & 0.02 & - & - & - & 0.01 & - & - & - & - & - & - & - & - & - & - & - \\
\hline$\Sigma$ & 98.31 & 99.34 & 100.02 & 100.40 & 99.21 & 99.56 & 99.74 & 100.67 & 98.95 & 99.36 & 99.44 & 99.98 & 99.85 & 100.04 & 99.67 & 99.62 & 99.50 \\
\hline Structural formulae ${ }^{a}$ & & & & & & & & & & & & & & & & & \\
\hline $\mathrm{Si}$ & 1.783 & 1.841 & 1.947 & 1.909 & 1.918 & 1.189 & 1.887 & 1.911 & 1.947 & 1.854 & 1.915 & 1.862 & 1.919 & 1.934 & 1.894 & 1.899 & 1.932 \\
\hline AIIV & 0.217 & 0.159 & 0.053 & 0.091 & 0.082 & 0.111 & 0.111 & 0.068 & 0.053 & 0.146 & 0.085 & 0.138 & 0.081 & 0.066 & 0.106 & 0.101 & 0.068 \\
\hline $\mathrm{Al}^{\mathrm{Vl}}$ & 0.019 & 0.248 & 0.012 & 0.044 & 0.018 & 0.012 & - & - & 0.036 & 0.061 & 0.031 & 0.046 & 0.023 & 0.004 & 0.035 & 0.011 & 0.012 \\
\hline $\mathrm{Ti}$ & 0.078 & 0.059 & 0.013 & 0.023 & 0.028 & 0.045 & 0.049 & 0.043 & 0.033 & 0.040 & 0.026 & 0.029 & 0.026 & 0.030 & 0.022 & 0.031 & 0.027 \\
\hline $\mathrm{Cr}$ & 0.009 & 0.004 & 0.007 & 0.012 & - & - & - & 0.002 & 0.001 & 0.007 & 0.002 & 0.017 & - & - & 0.008 & - & - \\
\hline $\mathrm{Fe}^{+3}$ & 0.065 & - & 0.025 & 0.011 & 0.032 & 0.041 & 0.045 & 0.049 & - & 0.020 & 0.023 & 0.042 & 0.027 & 0.028 & 0.041 & 0.052 & 0.021 \\
\hline $\mathrm{Fe}^{+2}$ & 0.334 & $\overline{0.376}$ & $\begin{array}{l}0.180 \\
0.180\end{array}$ & $\begin{array}{l}0.177 \\
0\end{array}$ & 0.311 & $\begin{array}{l}0.041 \\
0.396\end{array}$ & $\begin{array}{l}0.043 \\
0.417\end{array}$ & $\begin{array}{l}0.420 \\
0.42\end{array}$ & $\overline{0.594}$ & $\begin{array}{l}0.207 \\
\end{array}$ & 0.284 & 0.170 & 0.317 & 0.444 & 0.184 & 0.278 & 0.427 \\
\hline $\mathrm{Mn}$ & 0.008 & 0.009 & 0.006 & 0.005 & 0.011 & 0.010 & 0.011 & 0.012 & 0.014 & 0.006 & 0.009 & 0.005 & 0.010 & 0.014 & 0.006 & 0.009 & 0.011 \\
\hline $\mathrm{Mg}$ & 0.598 & 0.495 & 1.031 & 0.898 & 0.901 & 0.737 & 0.750 & 0.656 & 0.889 & 0.841 & 0.883 & 0.895 & 0.911 & 0.750 & 0.894 & 0.868 & 0.956 \\
\hline $\mathrm{Ca}$ & 0.872 & 0.736 & 0.714 & 0.809 & 0.679 & 0.734 & 0.709 & 0.821 & 0.408 & 0.796 & 0.724 & 0.778 & 0.669 & 0.709 & 0.794 & 0.735 & 0.532 \\
\hline $\mathrm{Na}$ & 0.028 & 0.056 & 0.016 & 0.022 & 0.023 & 0.031 & 0.027 & 0.026 & 0.020 & 0.023 & 0.021 & 0.024 & 0.021 & 0.025 & 0.021 & 0.024 & 0.017 \\
\hline$\Sigma$ & 4.011 & 3.983 & 4.004 & 4.001 & 4.003 & 4.006 & 4.006 & 4.008 & 3.995 & 4.001 & 4.003 & 4.006 & 4.004 & 4.004 & 4.005 & 4.008 & 4.003 \\
\hline $\mathrm{En}^{\mathrm{b}}$ & & & & & & & & & 47.0 & & 46.2 & 47.5 & 47.3 & 38.9 & 46.7 & 44.9 & 49.4 \\
\hline $\mathbf{F s} \mathrm{b}$ & $\begin{array}{l}33.9 \\
19.2\end{array}$ & $\begin{array}{r}23.8 \\
23.4\end{array}$ & $\begin{array}{l}32.9 \\
10.5\end{array}$ & $\begin{array}{l}4.4 \\
9.9\end{array}$ & $\begin{array}{l}4.9 \\
17.9\end{array}$ & $\begin{array}{l}38.0 \\
22.9\end{array}$ & 24.0 & $\begin{array}{l}34.1 \\
24.1\end{array}$ & $\begin{array}{l}4.0 \\
31.4\end{array}$ & $\begin{array}{l}4.1 \\
12.2\end{array}$ & $\begin{array}{l}4.2 \\
16.0\end{array}$ & 11.2 & 17.9 & 24.4 & 11.8 & 17.1 & 23.1 \\
\hline Wo ${ }^{b}$ & 46.9 & 45.8 & 36.6 & 42.7 & 35.2 & 38.5 & 36.9 & 42.2 & 21.6 & 42.7 & 37.8 & 41.3 & 34.8 & 36.7 & 41.5 & 38.0 & 27.5 \\
\hline $\mathrm{Mg} / \mathrm{Mg}+\mathrm{Fe}^{\text {total }}$ & 0.600 & 0.568 & 0.834 & 0.827 & 0.724 & 0.628 & 0.619 & 0.583 & 0.599 & 0.787 & 0.742 & 0.808 & 0.726 & 0.614 & 0.799 & 0.725 & 0.681 \\
\hline
\end{tabular}

a Structural formulae are computed for 6 oxygens.

$b$ Assuming that all iron is $\mathrm{Fe}+2$.

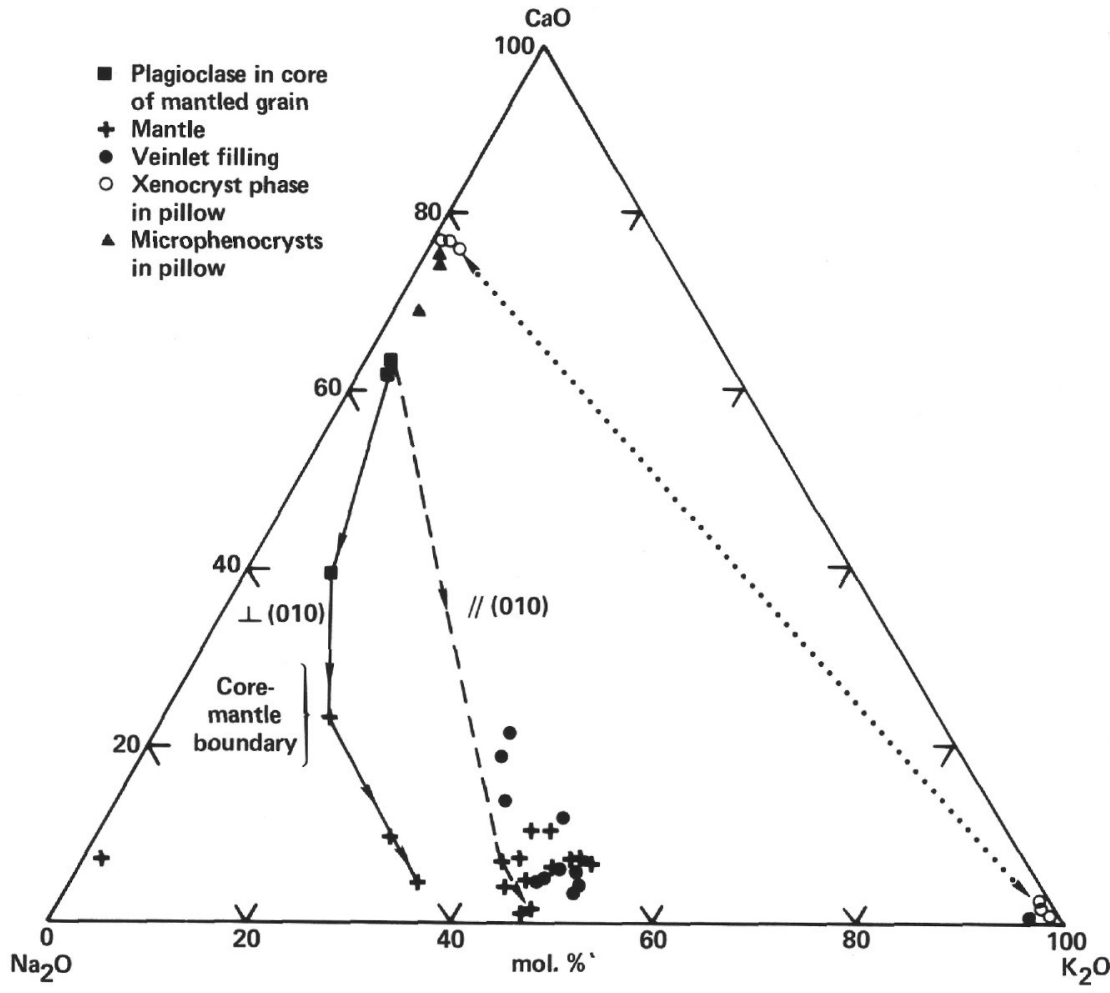

Figure 9. Feldspar compositions in alkaline pillows and upper sill of Hole 524. Solid and dashed lines connect coexisting phases in a single mantled grain (Sample 524-31-1, $108-111 \mathrm{~cm}$ ), measured in directions perpendicular to (010) (zoning continuous) and parallel to (010) (sharp jump from plagioclase to alkali feldspar). Dotted line connects coexisting phases in xenocryst in pillow lava (Sample 524-28-3, 70-72 cm). Arrows show direction of zoning from core to rim. 
Table 5. (Continued).

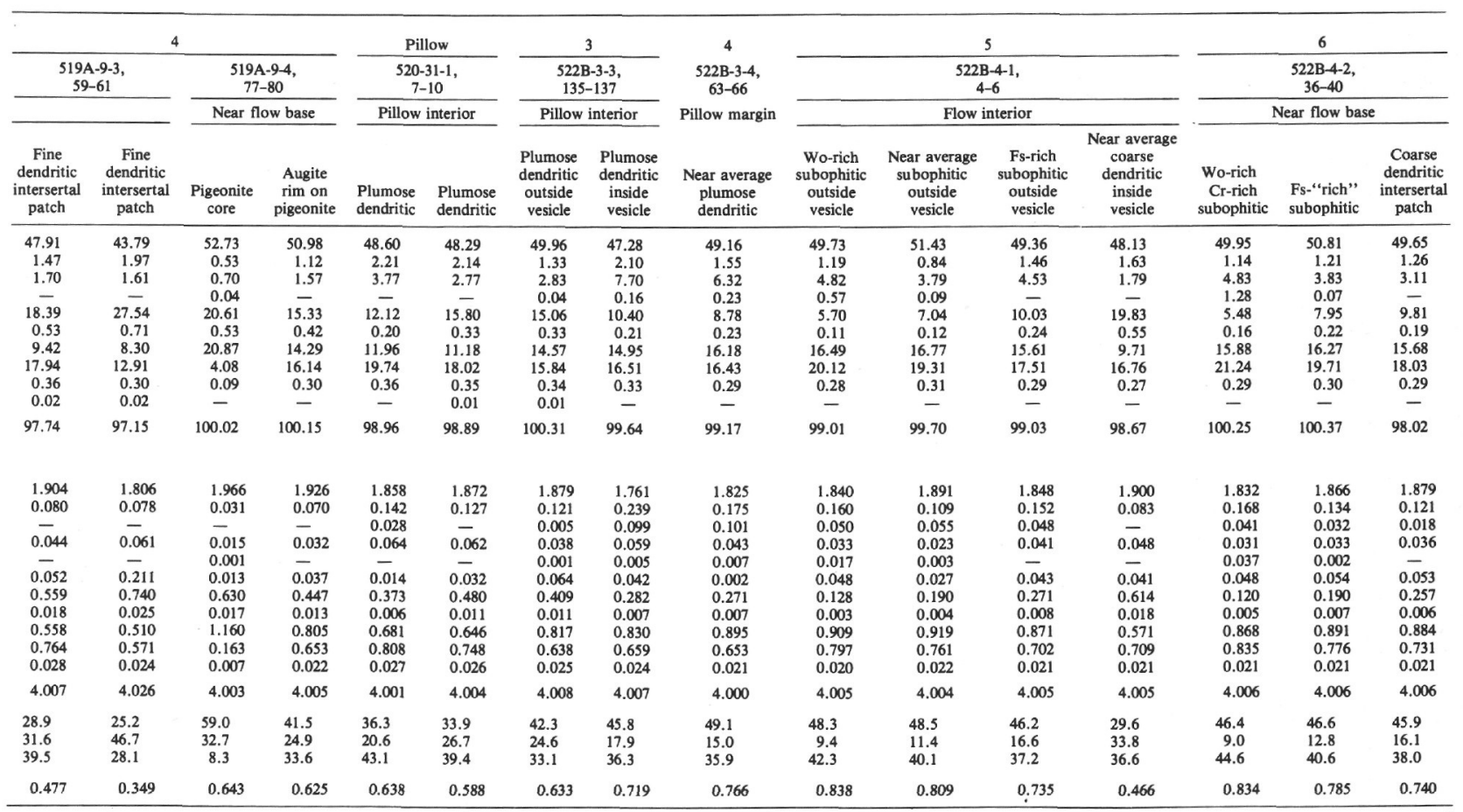

inantly augite in all rocks of all holes. However, the quench phases and outermost rims of zoned grains show compositions that vary widely, ranging from augite to salite, ferroaugite, and subcalcic augite. Pigeonite rimmed with augite was found with normal augite in Cooling Unit 4 of Hole 519A (Table 5, Sample 519A-9-4, $77-80 \mathrm{~cm}$ ), but it was not detected optically or chemically in any other rock. No orthopyroxene was found in any of the rocks examined.

Figure 10 shows the average compositions and the ranges of the compositions of different types of clinopyroxene in Holes 519A, 522B, and 524. In the figure "normal" augite-the augite in the cores of microphenocrysts in chilled rocks, ophitic grains, and large intergranular grains in coarser rocks-is distinguished from the clinopyroxenes in "quenched" grains (most of which are dendritic) and grains in "differentiated" residuum (the rims of zoned crystals and the smallest intergranular grains). Among the "quenched" grains a distinction is also made between the dendrites in the chilled margins of pillows and flows and the dendrites in intersertal patches in coarser rocks.

The compositions of the so-called normal clinopyroxenes cluster rather closely around $\mathrm{En}_{46} \mathrm{Fs}_{12} \mathrm{Wo}_{44}$ mol.\%, with nearly parallel trends in rocks of all holes toward ferrosilite enrichment in the "differentiated" grains (Fig. 10). The trends are typical of equilibrium crystallization (Kushiro and Nakamura, 1970; Smith and Lindsley, 1971).

The dendrites in the intersertal patches of the coarser rocks in Holes 519A and 522B represent "quenched" phases of the residual liquid left from the crystallization of the earlier phases, and they lie on the differentiation trends, mostly showing strong Fs enrichment (Fig. 10).
"Quenched" clinopyroxenes in pillows and chilled margins of flows in Hole 522B lie close to the EnFsWo values of "normal" grains, but on average they are slightly more Fs rich. The "quenched" phases from the most highly chilled rocks in Holes 519A and 524, on the other hand, show compositions that lie in the center of the salite field on parallel alignment from the respective "normal" compositions in those rocks (Fig. 10). These grains, mostly dendrites, presumably represent metastable crystallization, and it is notable that they are not the subcalcic augite that might be expected from liquids of compositions shown by the normative EnFsWo of the rocks in which they occur (Fig. 10).

The zoned clinopyroxene grains in the coarse rocks of Holes 519A and 524 (lower sill) were analyzed in some detail. Figure 11 shows the compositional trends from inner core to rim of several grains so analyzed. The grains from Hole 519A all show similar regular enrichment in iron from inner core to rim (Fig. 11, Samples 519-7-2, 50-52 cm and 519-9-3, 48-50 cm; and Table 5). However, an ophitic grain and an euhedral intergranular grain a few millimeters apart in the same rock (Sample 519-9-3, 48-50 cm) show markedly different trends as regards $\mathrm{Mg}$, with that element decreasing in the rim of the euhedral grain but increasing in the rim of the ophitic grain. Figure 12 illustrates these compositional trends in the clinopyroxene quadrilateral. The trends resemble the "quench" and the "equilibrium" trends of Smith and Lindsley (1971).

In the tholeiitic multiple lower sill of Hole 524, zoning in the clinopyroxene is unusual in that all zoned grains, both euhedral and ophitic, exhibit a decrease in iron and titanium in the outer core and a concomitant increase in magnesium and chromium (Fig. 11). All 
Table 5. (Continued).

\begin{tabular}{|c|c|c|c|c|c|c|c|c|c|c|c|c|c|}
\hline \multirow{2}{*}{$\begin{array}{l}\text { Cooling Unit } \\
\text { Sample } \\
\text { (interval in } \mathrm{cm} \text { ) }\end{array}$} & \multicolumn{3}{|c|}{7} & \multicolumn{4}{|c|}{10} & \multicolumn{2}{|c|}{13} & \multirow{3}{*}{$\begin{array}{c}\text { Pillow } \\
\text { 524-8-3, } \\
93-97\end{array}$} & \multicolumn{3}{|c|}{ Upper sill } \\
\hline & \multicolumn{3}{|c|}{$\begin{array}{c}522 \mathrm{~B}-4-2 \\
68-71\end{array}$} & \multicolumn{4}{|c|}{$\begin{array}{c}522 \mathrm{~B}-5-2 \\
126-130\end{array}$} & \multicolumn{2}{|c|}{$\begin{array}{c}522 \mathrm{~B}-6-1 \\
70-74\end{array}$} & & \multicolumn{3}{|c|}{$\begin{array}{c}524-30-2, \\
72-76\end{array}$} \\
\hline & \multicolumn{3}{|c|}{ Flow interior } & \multicolumn{4}{|c|}{ Flow interior } & \multicolumn{2}{|c|}{ Pillow? } & & \multicolumn{3}{|c|}{ Sill interior } \\
\hline Crystal type & $\begin{array}{l}\text { Average second- } \\
\text { generation } \\
\text { micro- } \\
\text { phenocryst }\end{array}$ & $\begin{array}{l}\text { Near average } \\
\text { subophitic }\end{array}$ & $\begin{array}{c}\text { Coarse } \\
\text { dendritic } \\
\text { intersertal } \\
\text { patch }\end{array}$ & Subophitic & Subophitic & Subophitic & $\begin{array}{c}\text { Coarse } \\
\text { dendritic }\end{array}$ & $\begin{array}{c}\text { Micro- } \\
\text { phenocryst }\end{array}$ & Subophitic & $\begin{array}{l}\text { Ti-rich } \\
\text { very fine } \\
\text { inter- } \\
\text { granular }\end{array}$ & $\begin{array}{c}\text { Near average } \\
\text { inter- } \\
\text { granular }\end{array}$ & $\begin{array}{c}\text { Fs-rich } \\
\text { inter- } \\
\text { granular }\end{array}$ & $\begin{array}{c}\text { Near average } \\
\text { inter- } \\
\text { granular }\end{array}$ \\
\hline $\mathrm{SiO}_{2}$ (wt.\%) & 50.95 & 50.26 & 48.77 & 52.03 & 51.38 & 50.52 & 48.49 & 52.35 & 51.19 & 43.08 & 51.99 & 50.12 & 51.88 \\
\hline $\mathrm{Al}_{2} \mathrm{O}_{3}$ & 4.07 & 3.93 & 5.71 & 3.76 & 3.14 & 2.88 & 2.32 & 2.66 & 4.02 & 7.50 & 2.01 & 3.06 & 1.44 \\
\hline $\mathrm{Cr}_{2} \mathrm{O}_{3}$ & 1.00 & 0.54 & - & 0.17 & - & - & 0.02 & - & 0.07 & 0.02 & 0.04 & 0.04 & 0.01 \\
\hline $\mathrm{FeO}$ & 5.25 & 5.36 & 7.17 & 5.71 & 8.93 & 13.51 & 17.99 & 5.45 & 7.49 & 10.25 & 8.93 & 11.43 & 9.41 \\
\hline $\mathrm{MnO}$ & 0.09 & 0.10 & 0.12 & - & 0.16 & 0.27 & 0.50 & 0.21 & 0.23 & 0.21 & 0.32 & 0.48 & 0.29 \\
\hline $\mathrm{MgO}$ & 17.17 & 16.95 & 14.76 & 15.90 & 15.62 & 14.75 & 9.52 & 17.89 & 16.72 & 10.89 & 15.06 & 14.28 & 14.56 \\
\hline $\mathrm{CaO}$ & 19.61 & 19.69 & 20.04 & 20.72 & 19.02 & 15.84 & 19.45 & 19.55 & 18.65 & 21.75 & 20.80 & 19.03 & 19.90 \\
\hline $\mathrm{Na}_{2} \mathrm{O}$ & 0.35 & 0.28 & 0.33 & 0.26 & 0.30 & 0.31 & 0.41 & 0.21 & 0.26 & 0.55 & 0.31 & 0.39 & 0.31 \\
\hline $\mathrm{K}_{2} \mathrm{O}$ & - & - & 0.03 & - & - & - & 0.02 & - & - & 0.02 & 0.01 & 0.01 & 0.01 \\
\hline$\Sigma$ & 99.27 & 97.82 & 98.37 & 99.42 & 99.80 & 99.43 & 100.77 & 98.75 & 99.64 & 99.34 & 100.71 & 100.29 & 98.71 \\
\hline \multicolumn{14}{|l|}{ Structural formula $\mathrm{e}^{\mathrm{a}}$} \\
\hline $\mathrm{Al}^{\mathrm{V}} \mathbf{l}$ & 0.050 & 0.048 & 0.081 & 0.081 & 0.043 & 0.035 & - & 0.045 & 0.061 & - & 0.007 & 0.008 & 0.021 \\
\hline $\mathrm{Ti}$ & 0.022 & 0.020 & 0.041 & 0.024 & 0.035 & 0.038 & 0.059 & 0.012 & 0.028 & 0.146 & 0.034 & 0.041 & 0.026 \\
\hline $\mathrm{Cr}$ & 0.029 & 0.016 & - & 0.005 & - & - & 0.001 & - & 0.002 & 0.001 & 0.001 & 0.001 & - \\
\hline $\mathrm{Fe}^{+3}$ & 0.029 & 0.040 & 0.034 & - & 0.004 & 0.005 & 0.071 & 0.016 & 0.014 & 0.120 & 0.025 & 0.065 & - \\
\hline $\mathrm{Fe}^{+2}$ & 0.132 & 0.127 & 0.191 & 0.176 & 0.273 & 0.421 & 0.509 & 0.152 & 0.217 & 0.207 & 0.251 & 0.293 & 0.297 \\
\hline Mn & 0.003 & 0.003 & 0.004 & - & 0.005 & 0.009 & 0.016 & 0.007 & 0.007 & 0.007 & 0.010 & 0.015 & 0.009 \\
\hline $\mathrm{Mg}$ & 0.941 & 0.943 & 0.825 & 0.873 & 0.863 & 0.830 & 0.547 & 0.983 & 0.918 & 0.620 & 0.829 & 0.795 & 0.819 \\
\hline $\mathrm{Ca}$ & 0.773 & 0.787 & 0.805 & 0.818 & 0.756 & 0.640 & 0.803 & 0.772 & 0.736 & 0.890 & 0.823 & 0.762 & 0.804 \\
\hline $\mathrm{Na}$ & 0.025 & 0.020 & 0.024 & 0.019 & 0.022 & 0.023 & 0.031 & 0.015 & 0.019 & 0.041 & 0.022 & 0.028 & 0.023 \\
\hline$\Sigma$ & 4.004 & 4.004 & 4.005 & 3.996 & 4.001 & 4.001 & 4.010 & 4.002 & 4.002 & 4.016 & 4.002 & 4.007 & 3.999 \\
\hline$E n^{b}$ & 50.2 & 49.7 & 44.5 & 46.8 & 45.5 & 43.7 & 28.4 & 51.1 & 48.7 & 33.8 & 43.0 & 41.5 & 42.6 \\
\hline $\mathrm{Fs}^{\mathrm{b}}$ & 8.6 & 8.8 & 12.1 & 9.4 & 14.6 & 22.5 & 30.0 & 8.7 & 12.3 & 17.8 & 14.3 & 18.7 & 15.5 \\
\hline$w_{0}^{b}$ & 41.2 & 41.5 & 43.4 & 43.8 & 39.9 & 33.8 & 41.6 & 40.2 & 39.0 & 48.4 & 42.7 & 39.8 & 41.9 \\
\hline $\mathrm{Mg} / \mathrm{Mg}+\mathrm{Fe}^{\text {total }}$ & 0.854 & 0.846 & 0.786 & 0.832 & 0.757 & 0.661 & 0.485 & 0.854 & 0.799 & 0.655 & 0.750 & 0.690 & 0.734 \\
\hline
\end{tabular}

+ Cores of microphenocrysts, ophitic grains, and large intergranular grains

Smallest intergranular groundmass grains and rims of microphenocrysts ophitic grains, and large intergranular grains

$\because \ddots$ Dendrites in chilled margins of pillows and flows and in intersertal patches of coarser rocks

A Normative En, Fs, and Wo of whole rock
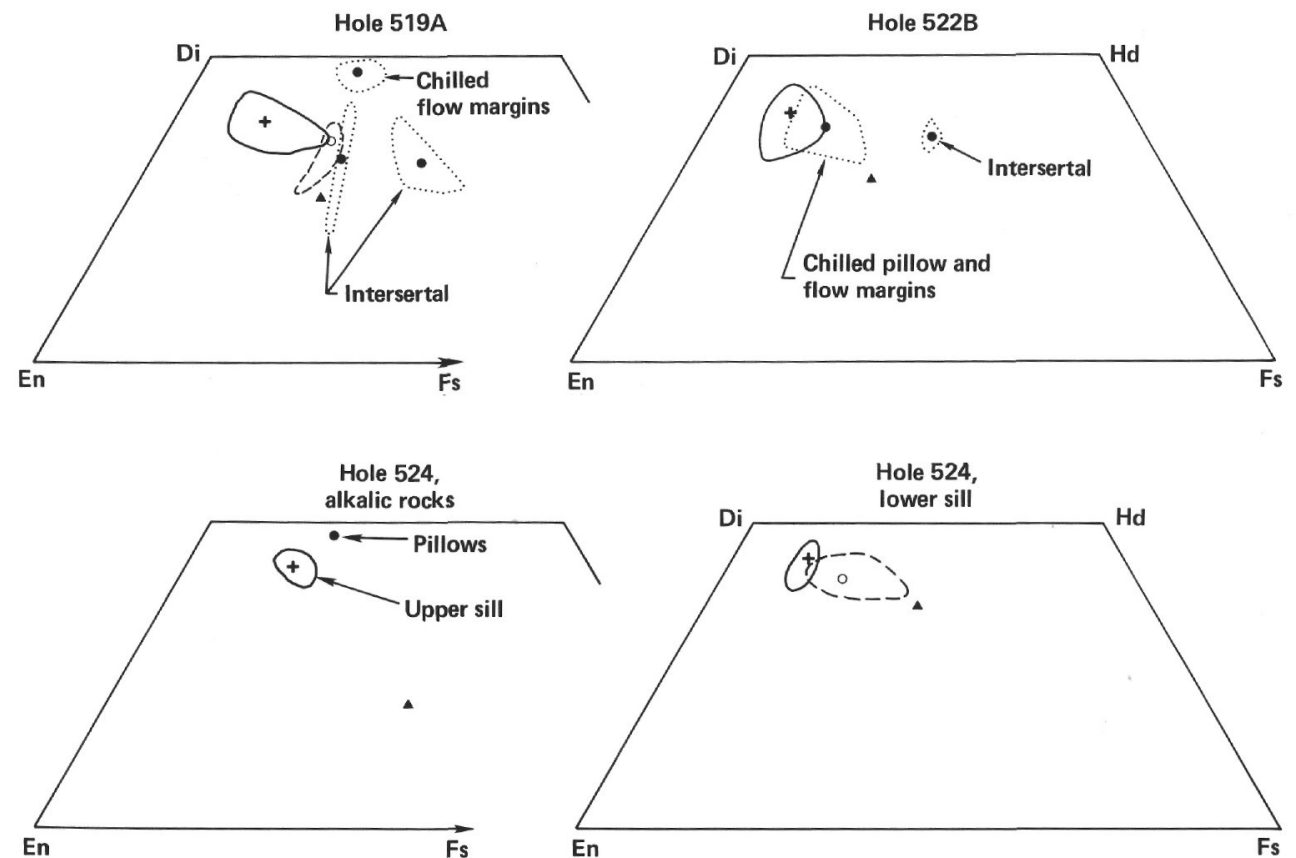

Figure 10. Ranges and average compositions of Ca-clinopyroxenes from different crystallization environments. 
Table 5. (Continued).

\begin{tabular}{|c|c|c|c|c|c|c|c|c|c|c|c|c|c|c|c|c|c|c|}
\hline \multicolumn{8}{|c|}{ Lower sill, upper part } & \multicolumn{6}{|c|}{ Lower sill, central part } & \multicolumn{5}{|c|}{ Lower sill, lower part } \\
\hline & \multicolumn{2}{|c|}{$\begin{array}{c}524-32-2, \\
127-133\end{array}$} & \multicolumn{5}{|c|}{$\begin{array}{c}524-33-1, \\
8-11 \\
\end{array}$} & \multicolumn{6}{|c|}{$\begin{array}{r}524-33-1, \\
112-116 \\
\end{array}$} & \multicolumn{5}{|c|}{$\begin{array}{c}524-34-1, \\
33-36 \\
\end{array}$} \\
\hline & & & \multicolumn{5}{|c|}{ Sill interior } & \multicolumn{6}{|c|}{ Sill interior } & \multicolumn{5}{|c|}{ Sill interior } \\
\hline \multicolumn{3}{|c|}{ Ophitic zoned grain } & \multicolumn{5}{|c|}{ Euhedral microphenocryst, $\perp c$-axis } & \multicolumn{5}{|c|}{ Ophitic zoned grain, $\sim \| c$-axis } & \multirow{2}{*}{$\begin{array}{c}\text { Near average } \\
\text { small } \\
\text { inter- } \\
\text { granular }\end{array}$} & \multicolumn{3}{|c|}{ Subhedral zoned microphenocryst } & \multirow{2}{*}{$\begin{array}{c}\text { Small } \\
\text { inter- } \\
\text { granular, } \\
\text { Fe-rich }\end{array}$} & \multirow{2}{*}{$\begin{array}{c}\text { Small } \\
\text { inter- } \\
\text { granular, } \\
\text { Fe-"'poor' }\end{array}$} \\
\hline $\begin{array}{l}\text { Ophi } \\
\begin{array}{l}\text { Inner } \\
\text { core }\end{array}\end{array}$ & $\begin{array}{c}\text { Outer } \\
\text { core }\end{array}$ & Rim & $\operatorname{Rim}(110)$ & $\begin{array}{c}\text { Euhedral mi } \\
\text { Outer core, } \\
\text { Fe-poor (110) }\end{array}$ & $\begin{array}{l}\text { cropheno } \\
\begin{array}{c}\text { Inner } \\
\text { core }\end{array}\end{array}$ & $\begin{array}{c}\text { ryst, Ic-axis } \\
\text { Outer core, } \\
\text { Fe-poor (100) }\end{array}$ & $\operatorname{Rim}(100)$ & $\underset{\sim(001)}{\operatorname{Rim}}$ & $\begin{array}{c}\text { Outer } \\
\text { core, } \\
\text { Fe-poor }\end{array}$ & $\begin{array}{l}\text { Inner } \\
\text { core }\end{array}$ & $\begin{array}{c}\text { Outer } \\
\text { core, } \\
\text { Fe-poor }\end{array}$ & $\begin{array}{c}\underset{\operatorname{Rim}}{\sim(001)} \\
\sim \text { (2) }\end{array}$ & & Subhed & $\begin{array}{l}\text { Outer core, } \\
\text { Fe-poor }\end{array}$ & Inner core & & \\
\hline 48.97 & 49.99 & 46.83 & 49.79 & 50.12 & 49.38 & 50.09 & 48.63 & 50.56 & 49.79 & 49.47 & 50.61 & 50.47 & 50.45 & 48.14 & 50.25 & 49.63 & 50.62 & 51.85 \\
\hline 0.89 & 0.83 & 1.60 & 1.35 & 0.85 & 1.00 & 0.81 & 1.58 & 1.24 & 0.86 & 1.26 & 0.74 & 1.02 & 1.27 & 2.13 & 0.88 & 1.24 & 1.05 & 0.72 \\
\hline 4.32 & 3.47 & 4.83 & 2.49 & 4.11 & 4.62 & 3.69 & 3.74 & 2.14 & 4.06 & 4.80 & 3.79 & 1.92 & 2.39 & 3.13 & 4.19 & 5.14 & 1.31 & 1.70 \\
\hline 0.12 & 0.63 & - & - & 0.99 & 0.68 & 0.89 & - & - & 0.68 & 0.31 & 0.85 & - & - & - & 0.93 & 0.77 & - & - \\
\hline 6.55 & 5.92 & 10.52 & 11.40 & 5.94 & 6.41 & 5.97 & 10.48 & 11.24 & 5.87 & 6.62 & 5.90 & 11.06 & 10.14 & 11.91 & 6.02 & 6.54 & 12.34 & 7.45 \\
\hline 0.08 & 0.05 & 0.18 & 0.29 & 0.08 & 0.08 & 0.11 & 0.15 & 0.28 & 0.09 & 0.08 & 0.08 & 0.27 & 0.21 & 0.24 & 0.09 & 0.09 & 0.32 & 0.14 \\
\hline 15.14 & 15.52 & 13.40 & 12.81 & 15.24 & 15.16 & 15.75 & 13.29 & 12.64 & 15.34 & 14.65 & 15.49 & 14.37 & 14.52 & 11.92 & 15.15 & 14.75 & 14.00 & 16.34 \\
\hline 21.75 & 22.46 & 20.25 & 20.79 & 21.43 & 21.09 & 21.68 & 20.52 & 20.46 & 21.06 & 20.88 & 20.74 & 18.71 & 19.71 & 20.58 & 21.41 & 20.76 & 18.88 & 20.59 \\
\hline 0.39 & 0.32 & 0.45 & 0.41 & 0.36 & 0.37 & 0.31 & 0.49 & 0.42 & 0.34 & $\begin{array}{r}0.00 \\
0.32\end{array}$ & 0.35 & 0.35 & 0.42 & 0.45 & 0.40 & 0.36 & 0.29 & 0.25 \\
\hline- & - & - & - & - & - & - & - & - & - & - & - & - & - & - & - & - & - & - \\
\hline 98.21 & 99.19 & 98.06 & 99.33 & 99.12 & 98.79 & 99.30 & 98.88 & 98.98 & 98.09 & 98.39 & 98.55 & 98.17 & 99.11 & 98.50 & 99.32 & 99.28 & 98.81 & 99.04 \\
\hline 1.837 & 1.857 & 1.788 & 1.888 & 1.862 & 1.842 & 1.857 & 1.843 & 1.923 & 1.867 & 1.855 & 1.888 & 1.923 & 1.899 & 1.850 & 1.864 & 1.844 & 1.928 & 1.929 \\
\hline 0.163 & 0.143 & 0.212 & 0.111 & 0.138 & 0.158 & 0.143 & 0.157 & 0.077 & 0.133 & 0.145 & 0.112 & 0.077 & 0.101 & 0.142 & 0.136 & 0.156 & 0.059 & 0.071 \\
\hline 0.028 & 0.009 & 0.006 & - & 0.042 & 0.045 & 0.018 & 0.010 & 0.019 & 0.046 & 0.067 & 0.054 & 0.009 & 0.005 & - & 0.047 & 0.070 & - & 0.004 \\
\hline 0.025 & 0.023 & 0.046 & 0.039 & 0.024 & 0.028 & 0.023 & 0.045 & 0.035 & 0.024 & 0.036 & 0.021 & 0.029 & 0.036 & 0.062 & 0.025 & 0.035 & 0.030 & 0.020 \\
\hline 0.004 & 0.018 & - & - & 0.029 & 0.020 & 0.026 & - & - & 0.020 & 0.009 & 0.025 & - & - & - & 0.027 & 0.023 & - & - \\
\hline 0.110 & 0.093 & 0.147 & 0.065 & 0.045 & 0.064 & 0.076 & 0.093 & 0.018 & 0.043 & 0.021 & 0.017 & 0.036 & 0.055 & 0.068 & 0.042 & 0.020 & 0.047 & 0.044 \\
\hline 0.096 & 0.091 & 0.189 & 0.296 & 0.140 & 0.136 & 0.110 & 0.239 & 0.339 & 0.141 & 0.186 & 0.167 & 0.316 & 0.264 & 0.315 & 0.145 & 0.183 & 0.346 & 0.187 \\
\hline 0.003 & 0.002 & 0.006 & 0.009 & 0.003 & 0.003 & 0.003 & 0.005 & 0.009 & 0.003 & 0.003 & 0.003 & 0.009 & 0.007 & 0.008 & 0.003 & 0.003 & 0.010 & 0.004 \\
\hline 0.847 & 0.859 & 0.763 & 0.724 & 0.844 & 0.843 & 0.870 & 0.751 & 0.717 & 0.857 & $\mathbf{0 . 8 1 9}$ & 0.861 & 0.816 & 0.815 & 0.683 & 0.838 & 0.817 & 0.795 & 0.906 \\
\hline 0.874 & 0.894 & 0.829 & 0.845 & 0.853 & 0.843 & 0.861 & 0.833 & 0.834 & 0.846 & 0.839 & 0.829 & 0.764 & 0.795 & 0.848 & 0.851 & 0.827 & 0.770 & 0.821 \\
\hline 0.028 & 0.023 & 0.033 & 0.030 & 0.026 & 0.027 & 0.002 & 0.036 & 0.031 & 0.025 & 0.023 & 0.025 & 0.026 & 0.031 & 0.034 & 0.029 & 0.026 & 0.021 & 0.018 \\
\hline 4.015 & 4.012 & 4.019 & 4.007 & 4.006 & 4.009 & 4.009 & 4.012 & 4.002 & 4.005 & 4.003 & 4.002 & 4.005 & 4.008 & 4.010 & 4.007 & 4.004 & 4.006 & 4.004 \\
\hline 44.0 & 44.4 & 39.6 & 37.5 & 44.9 & 44.7 & 45.4 & 39.2 & & & & 46.0 & 42.2 & 42.2 & 35.7 & 44.7 & 44.2 & 40.6 & 46.3 \\
\hline 10.7 & 9.5 & 17.4 & 18.7 & 9.8 & 10.6 & $\begin{array}{r}3.4 .4 \\
9.7\end{array}$ & 17.3 & $\begin{array}{l}18.0 \\
18.7\end{array}$ & $\begin{array}{r}3.4 \\
9.7\end{array}$ & 11.1 & 9.8 & 18.2 & 16.6 & 20.0 & 10.0 & 11.0 & 20.1 & 11.8 \\
\hline 45.3 & 46.1 & 43.0 & 43.8 & 45.3 & 44.7 & 44.9 & 43.5 & 43.7 & 44.9 & 45.0 & 44.2 & 39.6 & 41.2 & 44.3 & 45.3 & 44.8 & 39.3 & 41.9 \\
\hline 0.804 & 0.824 & 0.694 & 0.667 & 0.820 & 0.808 & 0.824 & 0.693 & 0.668 & 0.823 & 0.798 & 0.824 & 0.699 & 0.719 & 0.641 & 0.818 & 0.801 & 0.669 & 0.797 \\
\hline
\end{tabular}

Sample

$519 A-7-2,50-52 \mathrm{~cm}$

Cooling Unit 1

Flow interior

519A-9-3, 48-50 cm

Cooling Unit 4

Flow interior

519A-9-3, 48-50 cm

Cooling Unit 4

Flow interior

524-32-2, 127-133 cm

Lower sill

Upper part

524-33-1, 8-11 cm

Lower sill

Upper part
Grain type

Ophitic

Euhedral

intergranular

trend

Ophitic

"Quench" trend

Ophitic

Euhedral

cryst

$\sim \perp \mathrm{c}$

524-33-1, $112-116 \mathrm{~cm}$

Lower sill

Central part

Ophitic
"Equilibrium"

Location

Rim

Outer core

Inner core

Inner core

Rim

Outer core

Inner core

Outer core

Rim

Rim

Outer core

Inner core

Inner core

Inner core

Rim

Outer core

Inner core

Rim

Outer core

Inner core

Outer core

Rim
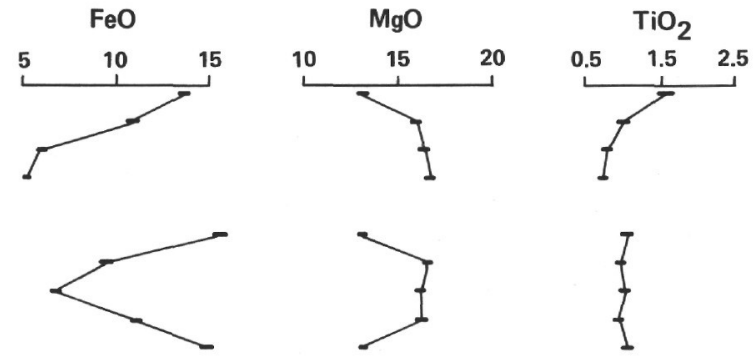

$I$
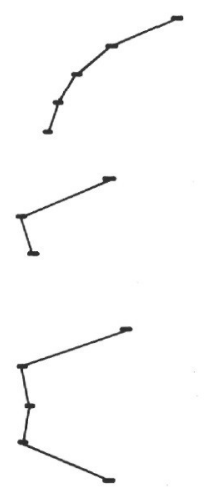

$\sim / / c$

Subhedral

micropheno-

cryst
Rim

uter core

Inner core

Outer core

Rim

Rim

Outer core

Inner core

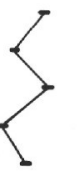

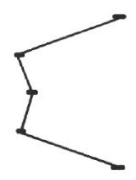
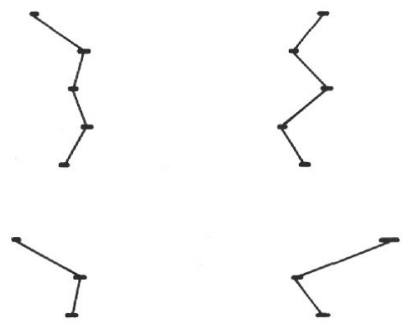

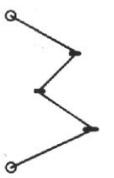

$\mathrm{Cr}_{2} \mathrm{O}_{3}$

$\begin{array}{llll}0.0 & 0.5 & 1.0\end{array}$

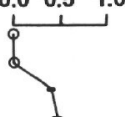

$f$

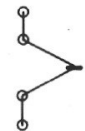

$I$
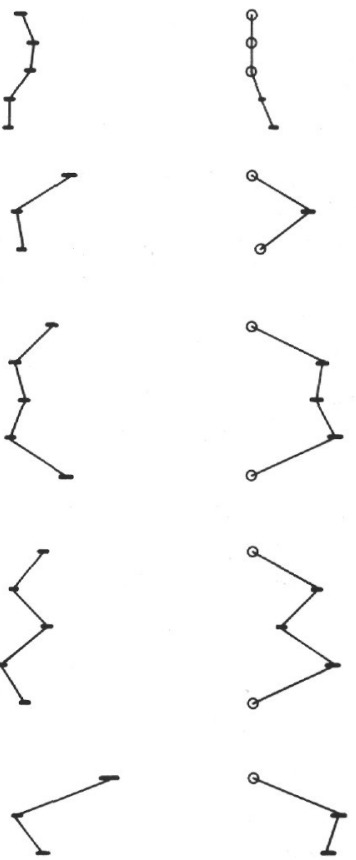

Figure 11. Compositional variation of zoned clinopyroxene crystals in rocks from Holes 519A and 524. Length of bars represents $2 \sigma$ confidence limits. 


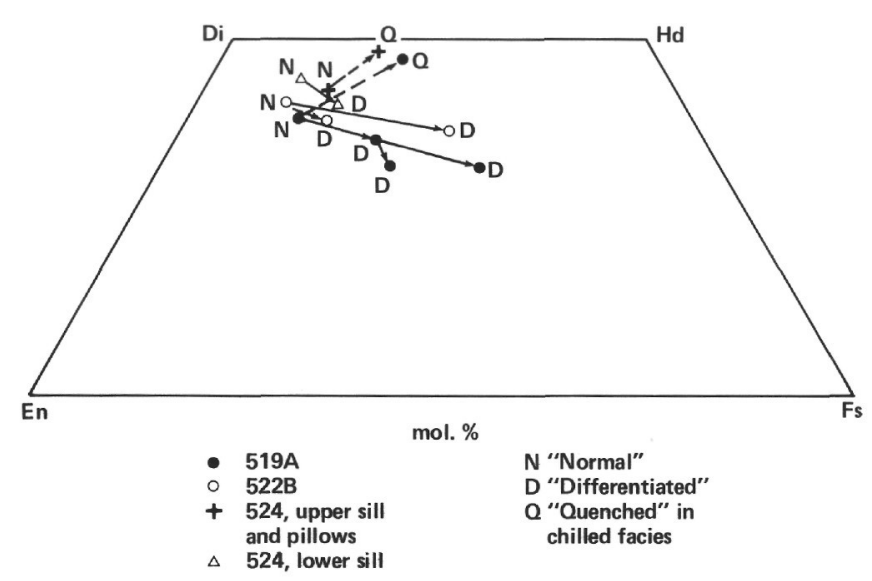

Figure 12. Trends of average composition of different types of Caclinopyroxenes from all holes. Arrows show direction of composition change from earlier to later forms.

these relations are then strongly reversed in the rim, which has a more normal pattern of iron, manganese, and titanium enrichment and magnesium and chromium depletion. Except for manganese, which varies in essentially the same way as iron, none of the other cations shows such systematic variation, and it appears as though it is confined to the $\mathbf{M}_{1}$ ions. The variation described is seen in grains cut both perpendicular and parallel to the c axis (P1. 6, Figs. 1-5). Precisely the same feature is visible in the grains from both the earlier upper and lower portions of the tholeiitic sill and those from the later central portion; thus, whatever the reason for it, the phenomenon repeated itself, apparently in situ, because the ophitic growth definitely occurred post-emplacement. Many of the clinopyroxene crystals in these rocks are irregularly sector zoned (Pl. 6, Fig. 1), and the iron-depleted zone extends through the sectors, suggesting that it is not related to the same phenomenon as the sector zoning. The sector zoning is more related to the kinetics of crystal growth and is a local effect at the crystal face, whereas the iron-depleted zone is more likely to have resulted from a more general variation in overall conditions in the magma. A factor such as variation of oxygen fugacity with crystallization is a possibility, but there is no good evidence of this in the ferric-ferrous ratios of the different compositional zones (Table 5).

No zoned crystals from Hole 522B rock were analyzed; however, as discussed under Small-Scale Structures and shown in Table 1, the clinopyroxene inside and outside the segregation vesicles in Cooling Unit 5 shows the same compositional changes as it does in the zoned grains of Hole 519A, the magma of which is very similar to that of Hole 522B. These changes include, as expected, increases in iron, manganese, and titanium and decreases in magnesium and chromium.

Overall, except for the temporary reversal of trend shown by the iron-depleted zone of the grains in the Hole 524 lower sill rocks, the clinopyroxenes in the basalts of Leg 73 display compositional variations typical of differentiating basaltic liquids. They exhibit both the equilibrium trends expected under conditions of rela- tively slow crystallization in the coarser rocks and the divergent trends in the chilled rocks that are to be expected under conditions of metastable or non-equilibrium crystallization.

If the values of $\mathrm{Ti}$ found in the clinopyroxene analyses are plotted versus the magnesium numbers $(\mathrm{Mg} / \mathrm{Mg}$ $+\mathrm{Fe}$ ), Ti increases as $\mathrm{Mg}$ decreases (Fig. 13A). The rate at which $\mathrm{Ti}$ increases slows considerably between $\mathrm{Mg}$ numbers of 0.75 and 0.78 . The higher $\mathrm{Mg}$ numbers are found in the cores of phenocrysts, ophitic grains, and the larger intergranular crystals (so-called normal clinopyroxene), whereas the $\mathrm{Mg}$ numbers below 0.70 are almost exclusively confined to grain rims and the finer groundmass grains, so-called differentiated clinopyroxene.

These observations are in keeping with the view that $\mathrm{Mg}$ number in clinopyroxene can be used as an indicator of differentiation in the melt from which the clinopyroxene crystals are forming. Sinton and Byerly (1980) made a similar observation and correlated the change in the rate of Ti increase with the beginning of the crystallization of the Fe-Ti oxides and the drop in iron in plagioclase. Thus they were able to infer the overall crystallization sequence of the rocks they were studying (Sinton and Byerly, 1980, fig. 10). The textures observed in the rocks of Leg 73 essentially fit the pattern
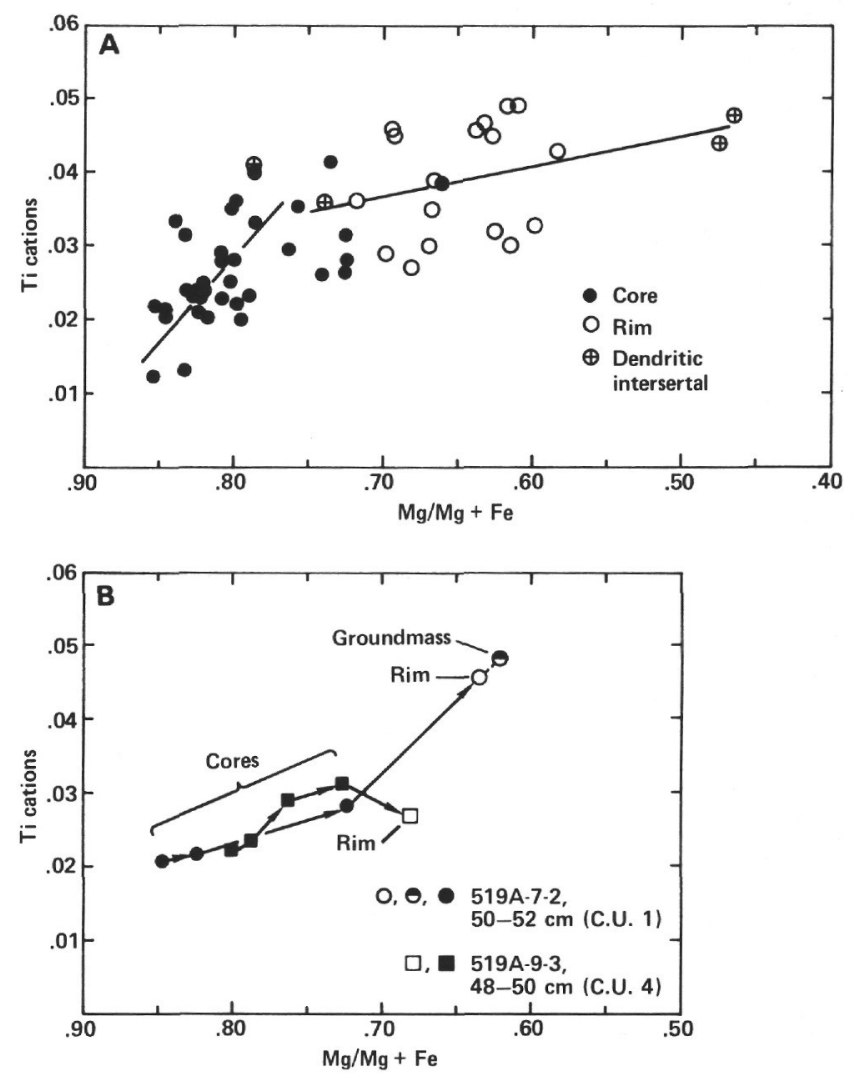

Figure 13. Relation of $\mathrm{Ti}$ cations versus $\mathrm{Mg}$ number $(\mathrm{Mg} / \mathrm{Mg}+$ $\mathrm{Fe}^{\text {total }}$ ) in clinopyroxenes of tholeiites. A. Composite of Holes 519A, 522B, and 524. Trend lines drawn by eye. B. Single crystals from Cooling Units 1 and 4 of Hole 519A. Arrows show direction of change from central core to outermost rim. 
found by Sinton and Byerly (cf. Fig. 5), and this pattern is probably valid for most oceanic basalts of the type found in Legs 51 to 53 and 73 (rather typical MORB).

Nevertheless, it is necessary to be careful about making generalizations when one is combining data from several cooling units, as is done in Figure 13A and by Sinton and Byerly (1980). Figure 13B shows data from two ophitic crystals from different cooling units in Hole 519A. Sample 519-9-3, 48-50 cm, from Cooling Unit 4, shows the pattern already discussed, but the change in $\mathrm{Ti}$ rate occurs at an $\mathrm{Mg}$ number of about $\mathbf{0 . 7 2}$. Sample $519-7-2,50-52 \mathrm{~cm}$, from the stratigraphically higher Cooling Unit 1, shows a steady increase in Ti from earliest to latest crystallization, with the change in Ti rate, if any occurs at all, taking the opposite direction (toward a higher rate of increase) between $\mathrm{Mg}$ numbers of 0.70 and 0.75 . The magmas of Cooling Units 1 and 4 are almost identical in overall composition (Dietrich et al., this vol.); the only difference is that Cooling Unit 1 has slightly more $\mathrm{Ti}$ than Cooling Unit 4 (the average for C.U. 1 is 1.28 ; for C.U. 4 the average is 1.22 ), and the $\mathrm{Fe}_{2} \mathrm{O}_{3} / \mathrm{FeO}$ of Cooling Unit 1 is lower than that of Cooling Unit 4 (the average for C.U. 1 is 0.30 ; for C.U. 4 the average is 0.67 ; Dietrich et al., this vol., table 2). The point in crystallization at which the $\mathrm{Fe}-\mathrm{Ti}$ oxides will begin to form relative to other phases is a function of such factors as oxygen fugacity (Osborn, 1959 and 1962) and perhaps cooling rate. Clearly, if clinopyroxene $\mathrm{Ti}$ content does reflect the beginning of Fe-Ti oxide formation, two magmas of essentially the same bulk composition had quite different crystallization histories as regards the formation of the opaque minerals relative to clinopyroxene. Moreover, the $\mathrm{Mg}$ number of clinopyroxene $(0.75)$ would appear to be an average value for magmas of the general composition under considera- tion, but the precise number at which the Fe-Ti oxides begin to crystallize clearly varies over a range of values under differing magmatic conditions.

\section{Fe-Ti Oxides}

The opaque minerals in the rocks of Holes 519A, 520 , and 522 formed after extrusion, and thus they occur as fine dendritic forms in the chilled rocks of those holes. In the more slowly cooled coarser rocks, there are larger cubes and octahedra of titanomagnetite and rods and hexagonal platelets of ilmenite that are more amenable to microprobe analysis than the smaller crystals in the finer rocks. Accordingly, the analyses discussed are mostly from such grains. In Hole 524 the opaque minerals occur as euhedral microphenocrysts in chilled rocks, as well as euhedral to anhedral intergranular grains in the coarser rocks of the sills. The unusual rectangular, reticulate rod-shaped aggregates of opaque minerals in the chilled phases of the alkalic rocks of Hole 524 (Pl. 7, Fig. 1) are titanomagnetites that appear under the microscope to be strings of intergrown octahedra.

Table 6 and Figure 14 show the composition of $\mathrm{Fe}-\mathrm{Ti}$ oxides of rocks from each of the holes. The ulvospinel content of titanomagnetites from all tholeiites and those from the alkalic upper sill of Hole 524 averages 64.4 mol. $\%$, a typical value for abyssal tholeiitic basalts (Clague et al., 1980; Kono et al., 1980; Genkin et al., 1980; Johnson and Hall, 1978; Ridley et al., 1976). The titanomagnetites from the alkalic pillows in Hole 524 are distinctive in that they are more $\mathrm{Fe}^{3+}$ rich and $\mathrm{Ti}$ poor (ulvospinel averages $49.8 \mathrm{~mol} . \%$ ). The rhombohedral phase, ilmenite, was analyzed only in the tholeiites of Hole 519A and the rocks of Hole 524. In the tholeiites and the alkalic upper sill of Hole 524 the hematite content of ilmenite averages $8.2 \mathrm{~mol} . \%$. As with the

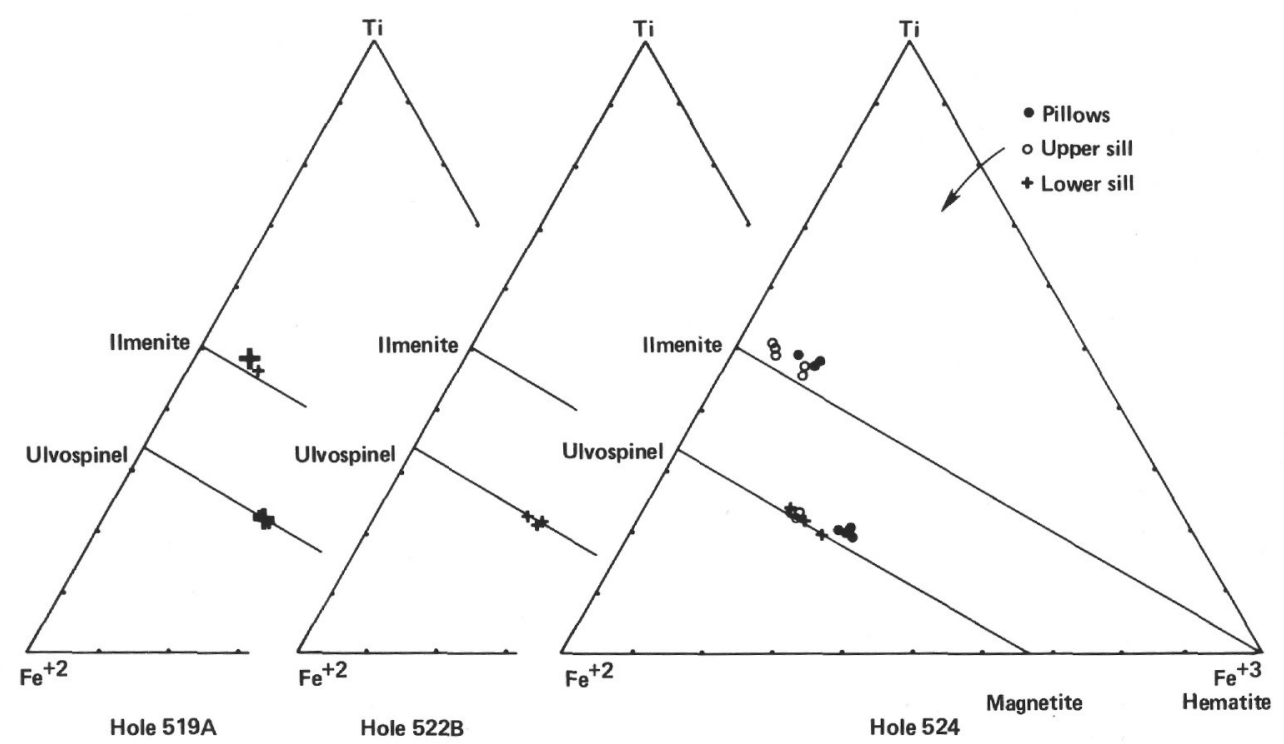

Figure 14. Ilmenite and ulvospinel contents of Leg $73 \mathrm{Fe}-\mathrm{Ti}$ oxides. Compositions diverge from pure series because wt. \% of trace elements ( $\mathrm{Si}, \mathrm{Al}, \mathrm{Mg}$, and $\mathrm{Mn}$ ) were not included in calculations. Larger crosses represent two or more analyses. 
Table 6A. Representative microprobe analyses of $\mathrm{Fe}-\mathrm{Ti}$ oxides.

\begin{tabular}{|c|c|c|c|c|c|c|c|c|c|c|}
\hline Mineral & Ilmenite & Titanomagnetite & Titanomagnetite & Titanomagnetite & Titanomagnetite & Titanomagnetite & Titanomagnetite & Titanomagnetite & Ilmenite & Ilmenite \\
\hline Cooling Unit & & 1 & & 2 & \multicolumn{6}{|c|}{4} \\
\hline $\begin{array}{l}\text { Sample } \\
\text { (interval in } \mathrm{cm} \text { ) }\end{array}$ & \multicolumn{2}{|r|}{$\begin{array}{c}519 A-7-2 \\
46-58\end{array}$} & $\begin{array}{c}519 \mathrm{~A}-7-2 \\
50-52\end{array}$ & $\begin{array}{c}\text { 519A-8-3 } \\
87-95\end{array}$ & $\begin{array}{c}519 \mathrm{~A}-9-3 \\
48-50\end{array}$ & \multicolumn{2}{|c|}{$\begin{array}{c}519 \mathrm{~A}-9-3, \\
59-61\end{array}$} & \multicolumn{3}{|c|}{$\begin{array}{c}519 \mathrm{~A}-9-4 \\
77-80\end{array}$} \\
\hline Location & \multicolumn{3}{|c|}{ Flow interior } & Flow interior & \multicolumn{6}{|c|}{ Flow interior } \\
\hline $\mathrm{SiO}_{2}$ (wt. $\%$ ) & 0.41 & 0.57 & 0.42 & 0.22 & 0.14 & 0.14 & 0.17 & 0.18 & 0.13 & 0.11 \\
\hline $\mathrm{TiO}_{2}$ & 46.39 & 21.95 & 23.85 & 22.33 & 22.12 & 22.79 & 22.96 & 23.17 & 48.30 & 48.43 \\
\hline $\mathrm{Al}_{2} \mathrm{O}_{3}$ & 0.26 & 1.65 & 1.67 & 1.39 & 1.43 & 1.36 & 1.45 & 1.45 & 0.16 & 0.19 \\
\hline $\mathrm{Cr}_{2} \mathrm{O}_{3}$ & - & - & - & - & - & - & - & - & - & - \\
\hline $\mathrm{FeO}^{-2}$ & 48.53 & 69.20 & 67.35 & 70.22 & 70.95 & 72.09 & 71.15 & 69.25 & 47.46 & 47.69 \\
\hline MnO & 0.72 & 0.57 & 0.68 & 0.41 & 0.47 & 0.67 & 0.56 & 0.57 & 0.41 & 0.57 \\
\hline $\mathrm{MgO}$ & 0.67 & 1.24 & 0.72 & 0.42 & 0.86 & 0.64 & 0.93 & 1.00 & 1.43 & 1.30 \\
\hline $\mathrm{CaO}$ & 0.27 & 0.10 & 0.09 & 0.19 & 0.16 & 0.07 & 0.20 & 0.08 & 0.18 & 0.17 \\
\hline$\Sigma$ & 97.25 & 95.28 & 94.78 & 95.18 & 96.13 & 97.76 & 97.42 & 95.70 & 98.07 & 98.46 \\
\hline \multicolumn{11}{|c|}{ Cations per 4 oxygens (titanomagnetite) or 3 oxygens (illmenite) } \\
\hline $\mathrm{Si}$ & 0.0105 & 0.0216 & 0.0161 & 0.0084 & 0.0053 & 0.0052 & 0.0063 & 0.0068 & 0.0033 & 0.0028 \\
\hline $\mathrm{Ti}$ & 0.8935 & 0.6242 & 0.6864 & 0.6413 & 0.6266 & 0.6366 & 0.6417 & 0.6593 & 0.9195 & 0.9192 \\
\hline Al & 0.0078 & 0.0735 & 0.0753 & 0.0626 & 0.0635 & 0.0595 & 0.0635 & 0.0647 & 0.0048 & 0.0057 \\
\hline & - & - & - & - & - & - & - & - & - & - \\
\hline $\mathrm{Fe}^{+2}$ & 0.8554 & 1.5536 & 1.6356 & 1.6048 & 1.5621 & 1.5825 & 1.5709 & 1.5882 & 0.8552 & 0.8563 \\
\hline $\mathrm{Fe}^{+3}$ & 0.1841 & 0.6349 & 0.5198 & 0.6380 & 0.6728 & 0.6568 & 0.6404 & 0.6031 & 0.1496 & 0.1503 \\
\hline $\mathrm{Mn}$ & 0.0156 & 0.0183 & 0.0221 & 0.0133 & 0.0150 & 0.0211 & 0.0176 & 0.0183 & 0.0088 & 0.0122 \\
\hline $\mathrm{Mg}$ & 0.0256 & 0.0699 & 0.0411 & 0.0239 & 0.0483 & 0.0354 & 0.0515 & 0.0564 & 0.0540 & 0.0489 \\
\hline $\mathrm{Ca}$ & 0.0074 & 0.0041 & 0.0037 & 0.0078 & 0.0065 & 0.0028 & 0.0080 & 0.0032 & 0.0049 & 0.0046 \\
\hline Ulvospinel $(\mathrm{mol} . \%)^{\mathrm{a}}$ & 10.65 & 63.57 & 70.05 & 65.80 & 62.91 & 63.62 & 64.11 & 65.68 & 8.05 & 8.08 \\
\hline
\end{tabular}

${ }^{\mathrm{a}}$ Quantities of ulvospinel shown under titanomagnetite may occur in hematite.

titanomagnetites, the ilmenites from the alkalic pillows of Hole 524 differ from those of other rocks; they are more hematite rich (average: $12.2 \mathrm{~mol} . \%$ ).

Minor elements in titanomagnetite are aluminum, magnesium, and manganese, with less silicon, calcium, and chromium. There are no systematic differences in abundance between the tholeiitic and alkalic rocks, with the alkalic upper sill in Hole 524 having minor element contents very similar to the flows and sills of Holes 519A and 522B. However, the alkalic pillows of Hole 524 are distinctive in that their titanomagnetites have unusually high $\mathrm{Al}_{2} \mathrm{O}_{3}$ (average: 4.0 wt. $\%$ ) and $\mathrm{MgO}$ (average: 3.5 wt. \%) as compared with the tholeiites $\left(\mathrm{Al}_{2} \mathrm{O}_{3}\right.$ averages 1.4 wt. \%; $\mathrm{MgO}$ averages $0.76 \mathrm{wt} . \%$ ). The pillows are further distinctive in that only their titanomagnetites contain significant chromium (average: 0.19 wt. \%). Titanomagnetite from Hole 520, in the one sample measured, is distinctive in having high silicon $\left(\mathrm{SiO}_{2}\right.$, 2.4 wt. \%) and calcium (CaO, 1.9 wt. \%).

As noted, ilmenites were analyzed only from Holes 519A and 524, and compared with the spinel phase, fewer were measured. The same minor elements were encountered in the ilmenites as were found in the titanomagnetites, and they are present in broadly similar amounts except that $\mathrm{Al}_{2} \mathrm{O}_{3}$ is distinctly lower (average: $0.28 \mathrm{wt} . \%$ ) in all ilmenites. Magnesium is high in the ilmenites of Hole 524 alkalic pillows, as it is in the spinel phase, and in these rocks the rhombohedral phase also carries a small amount of chromium.

\section{Chrome Spinel}

Chrome spinel was detected only in the rocks of Hole $519 \mathrm{~A}$, where it occurs as octahedral grains in first-generation plagioclase microphenocrysts (Pl. 7, Fig. 2). Table 7 gives representative spinel analyses, and Figure 15 contrasts the $\mathrm{Cr} / \mathrm{Cr}+\mathrm{Al}$ and $\mathrm{Mg} / \mathrm{Mg}+\mathrm{Fe}^{+2}$ of these samples with those of other oceanic basalts and komatiites. These spinels, which may be properly designated magnesiochromites, have compositions that fall close to the range for most abundant spinel types along the northern Mid-Atlantic Ridge (Sigurdsson and Schilling, 1976), but they are generally more $\mathrm{Mg}$ poor than the spinels that occur farther north. The spinels from Hole 519A are relatively low in both $\mathrm{Mg}$ and $\mathrm{Cr}$ compared with more primitive MORB, characteristics in keeping with other chemical indicators that the Hole 519C rocks are moderately evolved. The basalts from all other Leg 73 sites are even more evolved, and no spinels were detected in any of them.

All of the chrome spinels listed in Table 7 have $\mathrm{Cr}$ slightly higher than $\mathrm{Al}$, perhaps suggesting equilibration at intermediate pressure (Sigurdson and Schilling, 1976), although other factors may also affect this relation, such as oxygen fugacity and the composition of the liquid (Ridley, 1977).

\section{Biotite}

The alkalic upper sill of Hole 524 contains tiny (0.02-0.2 $\mathrm{mm}$ ) euhedral to subhedral flakes of biotite, pleochroic golden yellow $(\mathrm{X})$ to dark orange brown (Y $=\mathrm{Z}$ ), with $2 \mathrm{~V}_{\mathrm{X}}$ close to $\mathrm{O}^{\circ}$. This mica occurs in the groundmass (PI. 7, Fig. 3), where it is often associated with brown and green smectite and chloritic patches, many of which are pseudomorphs of olivine. In some instances the biotite is interleaved with the green phyllosilicate and appears to be altering to it. Many biotite grains have an opaque cryptocrystalline border. These relations reflect the rather thorough deuteric alteration the sill has undergone. Table 8 gives the chemical analyses of the biotites. They are all low in aluminum, and hence no $\mathrm{Al}^{\mathrm{VI}}$ is assumed.

\section{Amphibole}

The alkalic nature of the upper sill of Hole 524 is reflected in the occurrence of very sparse tiny $(0.01-0.2$ $\mathrm{mm}$ ) subhedral, stubby, prismatic amphibole grains in the groundmass (Pl. 7, Fig. 4). The grains are pleochroic from very pale grass green $(\mathrm{X})$ to deep bluish green 
Table 6A. (Continued).

\begin{tabular}{|c|c|c|c|c|c|c|c|c|c|c|c|}
\hline Titanomagnetite & Titanomagnetite & Titanomagnetite & Titanomagnetite & Titanomagnetite & Ilmenite & Titanomagnetite & Tjtanomagnetite & Titanomagnetite & Ilmenite & Titanomagnetite & Ilmenite \\
\hline Pillow & & 5 & 6 & 13 & \multicolumn{7}{|c|}{ Pillow } \\
\hline $\begin{array}{c}520-31-1 \\
7-10\end{array}$ & \multicolumn{2}{|c|}{$\begin{array}{c}522 \mathrm{~B}-4-1, \\
4-6\end{array}$} & $\begin{array}{c}522 \mathrm{~B}-4-2 \\
36-40\end{array}$ & $\begin{array}{c}522 \mathrm{~B}-6-1, \\
70-74\end{array}$ & \multicolumn{7}{|c|}{$\begin{array}{c}524-28-3 \\
70-72\end{array}$} \\
\hline Pillow interior & \multicolumn{2}{|c|}{ Flow interior } & Flow interior & Flow interior & \multicolumn{7}{|c|}{ Pillow interior } \\
\hline 2.42 & 0.58 & 0.78 & 1.01 & 0.84 & 0.19 & 0.14 & 0.14 & 0.46 & 0.47 & 0.49 & 0.46 \\
\hline 22.00 & 21.35 & 22.19 & 20.28 & 20.05 & 46.14 & 18.19 & 18.05 & 17.98 & 45.99 & 18.66 & 46.56 \\
\hline 2.21 & 1.03 & 1.41 & 1.89 & 1.85 & 0.32 & 3.59 & 4.56 & 3.97 & 0.48 & 4.03 & 0.46 \\
\hline- & - & - & - & - & - & 0.16 & 0.38 & 0.08 & 0.03 & 0.12 & 0.05 \\
\hline 64.63 & 72.72 & 70.50 & 69.92 & 70.01 & 43.64 & 65.46 & 62.61 & 67.29 & 46.26 & 66.61 & 45.67 \\
\hline 0.51 & 0.69 & 0.62 & 0.58 & 0.46 & 0.50 & 0.42 & 0.34 & 0.50 & 0.61 & 0.57 & 0.39 \\
\hline 0.80 & 0.26 & 0.65 & 0.55 & 0.59 & 2.85 & 4.03 & 5.47 & 4.42 & 3.36 & 3.96 & 4.19 \\
\hline 1.88 & 0.17 & 0.17 & 0.37 & 0.35 & 0.26 & 0.15 & 0.14 & 0.17 & 0.21 & 0.13 & 0.16 \\
\hline 94.45 & 96.80 & 96.32 & 94.60 & 94.15 & 93.90 & 92.14 & 91.68 & 94.87 & 97.41 & 94.57 & 97.94 \\
\hline 0.0916 & 0.0218 & 0.0293 & 0.0385 & 0.0322 & 0.0050 & 0.0053 & 0.0049 & 0.0168 & 0.0117 & 0.0180 & 0.0114 \\
\hline 0.6262 & 0.6035 & 0.6276 & 0.5816 & 0.5778 & 0.9046 & 0.5116 & 0.5069 & 0.4935 & 0.8638 & 0.5159 & 0.8646 \\
\hline 0.0986 & 0.0456 & 0.0625 & 0.0849 & 0.0836 & 0.0098 & 0.1598 & 0.2007 & 0.1708 & 0.0141 & 0.1746 & 0.0134 \\
\hline- & - & - & - & - & - & 0.0048 & 0.0112 & 0.0023 & 0.0006 & 0.0035 & 0.0010 \\
\hline 1.5801 & 1.5819 & 1.5939 & 1.5550 & 1.5470 & 0.7805 & 1.2755 & 1.1909 & 1.2477 & 0.7319 & 1.2940 & 0.7093 \\
\hline 0.4657 & 0.7039 & 0.6235 & 0.6748 & 0.6965 & 0.1710 & 0.7917 & 0.7645 & 0.8063 & 0.2343 & 0.7540 & 0.2337 \\
\hline 0.0164 & 0.0220 & 0.0198 & 0.0187 & 0.0149 & 0.0110 & 0.0134 & 0.0108 & 0.0155 & 0.0129 & 0.0178 & 0.0082 \\
\hline 0.0451 & 0.0146 & 0.0364 & 0.0313 & 0.0337 & 0.1108 & 0.2268 & 0.3045 & 0.2405 & 0.1251 & 0.2170 & 0.1542 \\
\hline 0.0762 & 0.0068 & 0.0069 & 0.0151 & 0.0144 & 0.0073 & 0.0061 & 0.0056 & 0.0066 & 0.0056 & 0.0051 & 0.0042 \\
\hline 72.99 & 62.04 & 65.35 & 63.11 & 62.32 & 9.54 & 50.15 & 48.34 & 48.75 & 13.62 & 51.83 & 13.54 \\
\hline
\end{tabular}

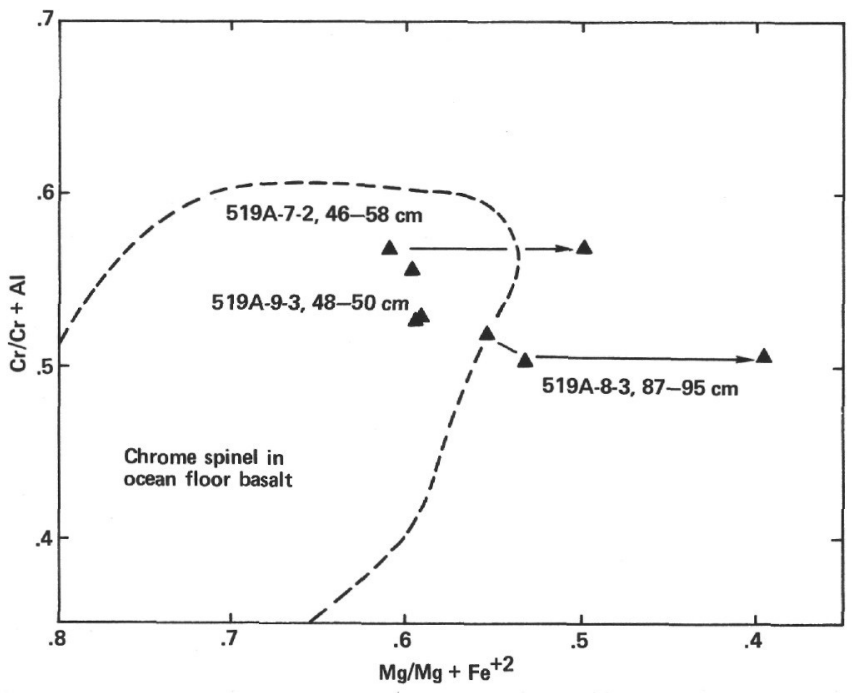

Figure 15. Relations of $\mathrm{Cr} / \mathrm{Cr}+\mathrm{Al}$ versus $\mathrm{Mg} / \mathrm{Mg}+\mathrm{Fe}^{+2}$ cation ratios of spinels from Hole 519A.

$(\mathrm{Y}=\mathrm{Z})$, with $2 \mathrm{~V}_{\mathrm{X}}$ about $60^{\circ}$ and typically small extinction angles $\left(<20^{\circ}\right)$. Table 9 gives the composition of two grains, showing them to be calcian magnesioriebeckite (Hawthorne, 1981, table 5).

\section{Geothermometry}

\section{Plagioclase Geothermometer}

The plagioclase-glass geothermometer devised by Kudo and Weill (1970) and revised by Drake (1976) was used to calculate the temperature of plagioclase-glass equilibration in one rock in which first-generation plagioclase microphenocrysts are in contact with unaltered glass (Sample 522B-4-2, 68-72 cm). The compositions of the outer rims of two grains were used together with the average of the analyses of three spots on the glass; all analyses were done with the electron microprobe (Table 10). The results for dry conditions and 1 bar of pressure $\left(1332\right.$ and $\left.1278^{\circ} \mathrm{C}\right)$ are too high. The KudoWeill value of $1210^{\circ} \mathrm{C}$ is more credible, but the question arises as to what the water pressure was when the phenocrysts were last in equilibrium with the liquid.

\section{Fe-Ti Oxide Geothermometer}

The temperature of last equilibrium between the cubic (spinel) and rhombohedral iron-titanium oxide phases has been determined for a few rocks by using the algorithms of Ghiorso and Carmichael (1981). The results are given in Table 11. The temperature for the flows of Hole 519A can be considered to be within the range of crystallization temperatures for basalt, but those for the rocks of Hole 524 are mostly too low and presumably represent subsolidus temperatures of equilibration. A search was made for exsolution. It was found to be exceedingly rare in these rocks, but a more thorough study should be made before more than tentative conclusions can be drawn.

\section{SUMMARY AND CONCLUSIONS}

The textures of Leg 73 deep sea basalts show the expected variations related to rate of cooling and chemistry of the cooling liquid. As pointed out by others (Kirkpatrick, 1979; Natland, 1979), quench textures vary dramatically and systematically in the outer few centimeters of lava flows and pillows, and in general they can be used to estimate the proximity of the sample to the margin of the body. A sequence of textures in which all or most phases show dendritic or skeletal growth is typical of the quenched rocks. Such textures extend throughout pillows as thick as $40 \mathrm{~cm}$, whereas in lava flows the zone of quenched textures is limited to the outer few centimeters (typically $2-4 \mathrm{~cm}$ ). The sequence of crystallization in the rocks from the different holes reflects the degree of the magmatic evolution of the lavas in those holes. The magma in Hole 519A is least but still moderately evolved, with only calcic plagioclase crystallizing prior to eruption, and the magmas of Hole 
Table 6A. (Continued).

\begin{tabular}{|c|c|c|c|c|c|c|c|c|c|c|}
\hline Ilmenite & & Titanomagnetite & Titanomagnetite & Ilmenite & Ilmenite & Ilmenite & Titanomagnetite & Titanomagnetite & Titanomagnetite & Titanomagnetite \\
\hline & s sill & & Upper sill & & & & pper sill & $\begin{array}{l}\text { Low } \\
\text { centr }\end{array}$ & $\begin{array}{l}\text { r sill, } \\
\text { i part }\end{array}$ & $\begin{array}{l}\text { Lower sill, } \\
\text { lower part }\end{array}$ \\
\hline & $\begin{array}{l}29-1, \\
105\end{array}$ & & $\begin{array}{c}524-31-1, \\
108-111\end{array}$ & & & & $\begin{array}{l}24-31-2 \\
87-90\end{array}$ & $\begin{array}{r}524 \\
112 \\
\end{array}$ & $\begin{array}{l}13-1, \\
116\end{array}$ & $\begin{array}{c}524-34-1 \\
74-79\end{array}$ \\
\hline Sill & argin & & Sill interior & & & & 11 interior & Sill is & terior & Sill interior \\
\hline 0.10 & 0.14 & 0.15 & 0.15 & 0.10 & 0.07 & 0.20 & 0.16 & 0.17 & 0.19 & 1.29 \\
\hline 46.73 & 45.68 & 22.21 & 23.01 & 50.42 & 50.31 & 50.05 & 22.80 & 22.95 & 21.62 & 18.87 \\
\hline 0.39 & 0.24 & 1.30 & 1.47 & 0.10 & 0.09 & 0.03 & 0.66 & 1.72 & 2.00 & 1.21 \\
\hline- & - & - & - & - & - & - & - & - & - & - \\
\hline 47.93 & 49.55 & 69.45 & 69.19 & 45.63 & 44.94 & 47.18 & 69.83 & 68.97 & 68.91 & 69.83 \\
\hline 0.55 & 0.64 & 0.92 & 0.81 & 0.87 & 0.89 & 0.94 & 1.09 & 0.62 & 0.64 & 1.64 \\
\hline 1.97 & 0.66 & 0.46 & 0.77 & 2.00 & 2.14 & 1.26 & 0.86 & 0.89 & 1.21 & 0.88 \\
\hline 0.13 & 0.08 & 0.09 & 0.06 & 0.14 & 0.16 & 0.10 & 0.07 & 0.08 & 0.14 & 0.16 \\
\hline 97.80 & 96.99 & 94.58 & 95.46 & 99.26 & 98.60 & 99.76 & 95.47 & 95.40 & 94.71 & 93.88 \\
\hline 0.0026 & 0.0036 & 0.0058 & 0.0057 & 0.0025 & 0.0018 & 0.0050 & 0.0061 & 0.0065 & 0.0072 & 0.0495 \\
\hline 0.8860 & 0.8823 & 0.6422 & 0.6576 & 0.9460 & 0.9493 & 0.9389 & 0.6528 & 0.6548 & 0.6180 & 0.5446 \\
\hline 0.0117 & 0.0073 & 0.0589 & 0.0658 & 0.0029 & 0.0027 & 0.0009 & 0.0296 & 0.0769 & 0.0896 & 0.0547 \\
\hline- & - & - & - & - & - & - & - & - & - & - \\
\hline 0.7967 & 0.8408 & 1.5879 & 1.5911 & 0.8520 & 0.8478 & 0.8695 & 1.5731 & 1.5877 & 1.5303 & 1.4838 \\
\hline 0.2138 & 0.2234 & 0.6452 & 0.6077 & 0.1001 & 0.0952 & 0.1147 & 0.6519 & 0.6006 & 0.6600 & 0.7571 \\
\hline 0.0115 & 0.0139 & 0.0300 & 0.0261 & 0.0184 & 0.0189 & 0.0199 & 0.0352 & 0.0199 & 0.0206 & 0.0533 \\
\hline 0.0742 & 0.0253 & 0.0264 & 0.0436 & 0.0744 & 0.0800 & 0.0469 & 0.0488 & 0.0503 & 0.0686 & 0.0503 \\
\hline 0.0035 & 0.0022 & 0.0037 & 0.0024 & 0.0037 & 0.0043 & 0.0027 & 0.0029 & 0.0033 & 0.0057 & 0.0066 \\
\hline 11.28 & 11.57 & 63.69 & 65.22 & 5.40 & 5.07 & 5.80 & 65.71 & 65.89 & 62.15 & 54.95 \\
\hline
\end{tabular}

Table 6B. Mean and standard deviation, $\sigma$, for ulvospinel, $\mathrm{Al}_{2} \mathrm{O}_{3}$, and $\mathrm{MgO}$ in Fe-Ti oxides.

\begin{tabular}{|c|c|c|c|c|}
\hline & \multicolumn{2}{|c|}{$\begin{array}{l}\text { Tholeiites (Holes 519A, } \\
520 \text {, and 524) and } \\
\text { alkalic upper sill } \\
\text { (Hole 524) }\end{array}$} & \multicolumn{2}{|c|}{$\begin{array}{l}\text { Alkalic pillows } \\
\text { (Hole 524) }\end{array}$} \\
\hline & Mean & $\sigma$ & Mean & $\sigma$ \\
\hline $\begin{array}{l}\text { Ulvospinel in titanomagnetite } \\
\text { or hematite (mol. \%) }\end{array}$ & 64.40 & 3.77 & 49.77 & 1.58 \\
\hline Ulvospinel in ilmenite (mol.\%) & 8.24 & 2.68 & 12.23 & 2.33 \\
\hline $\mathrm{Al}_{2} \mathrm{O}_{3}$ in titanomagnetite (wt. \%) & 1.51 & 0.36 & 4.04 & 0.40 \\
\hline $\mathrm{Al}_{2} \mathrm{O}_{3}$ in ilmenite (wt. \%) & 0.18 & 0.11 & 0.42 & 0.09 \\
\hline $\mathrm{MgO}$ in titanomagnetite (wt. \%) & 0.76 & 0.26 & 4.47 & 0.70 \\
\hline $\mathrm{MgO}$ in ilmenite (wt. \%) & 1.43 & 0.58 & 3.47 & 0.68 \\
\hline
\end{tabular}

Table 7. Representative microprobe spinel analyses from Hole 519A.

\begin{tabular}{|c|c|c|c|c|c|c|c|c|}
\hline \multirow{2}{*}{$\begin{array}{l}\text { Core-Section } \\
\text { (interval in cm) }\end{array}$} & \multicolumn{3}{|c|}{$7-2$} & \multicolumn{3}{|c|}{$8-3$} & \multicolumn{2}{|c|}{$9-3$} \\
\hline & $46-58$ & $46-58$ & $46-58$ & $87-95$ & $87-95$ & $87-95$ & $48-50$ & $48-50$ \\
\hline $\mathrm{iO}_{2}$ (wt.\%) & 0.18 & 0.17 & 0.13 & 0.15 & 0.13 & 0.17 & 0.15 & 0.15 \\
\hline $\mathrm{TiO}_{2}$ & & & & & 0.64 & & 0.69 & 0.69 \\
\hline $\mathrm{Al}_{2} \mathrm{O}_{3}$ & 21.27 & 21.52 & 20.20 & 23.35 & 24.84 & 24.28 & 23.51 & 23.05 \\
\hline $\mathrm{Cr}_{2} \mathrm{O}_{3}$ & 40.89 & 40.25 & 39.81 & 37.54 & 37.43 & 36.82 & 38.93 & 38.49 \\
\hline $\mathrm{Fe}_{2} \mathrm{O}_{3} \mathrm{a}$ & 7.31 & 7.02 & 8.29 & 7.28 & 6.31 & 6.13 & 6.79 & 7.37 \\
\hline $\mathrm{FeO}$ & 15.22 & 15.56 & 19.04 & 17.03 & 18.05 & 22.84 & 15.80 & 15.75 \\
\hline $\mathrm{MgO}$ & 13.34 & 12.94 & 10.78 & 11.94 & 11.61 & 8.40 & 13.03 & 12.91 \\
\hline MnO & 0.23 & 0.24 & 0.29 & 30 & 0.33 & 0.36 & 0.25 & 0.24 \\
\hline $\mathrm{CaO}$ & 0.31 & 0.33 & 0.10 & 0.31 & 0.33 & 0.37 & 0.27 & 0.28 \\
\hline$\Sigma$ & 99.63 & 98.88 & 99.52 & 98.55 & 99.67 & 99.91 & 99.42 & 98.93 \\
\hline $\mathrm{Si}$ & 0.045 & 0.042 & 0.033 & 0.038 & & & & 0.037 \\
\hline $\mathrm{Ti}$ & 0 & 0.1 & & 0.1 & 0.1 & & & 0.129 \\
\hline Al & 6.212 & 6.333 & 6.038 & 6.886 & 7.226 & 7.2 & 6.829 & 6.742 \\
\hline $\mathrm{Cr}_{3}$ & 8.008 & 7.943 & 7.979 & 7.424 & 7.301 & 7.3 & 7.583 & 7.550 \\
\hline $\mathrm{Fe}^{3+}$ & 1.363 & 1.319 & 1.581 & 1.371 & 1.171 & 1.16 & 1.258 & 1.376 \\
\hline $\mathrm{Fe}^{2+}$ & 3.153 & 3.249 & 4.038 & 3.562 & 3.72 & & 3.257 & 3.267 \\
\hline Mg & 4.925 & 4.814 & 4.073 & 4.451 & 4.269 & & 4.785 & 4.774 \\
\hline Mn & 0.048 & 0.051 & 0.062 & 0.064 & 0.069 & 0.077 & 0.052 & 0.050 \\
\hline $\mathrm{Ca}$ & 0.082 & 0.088 & 0.027 & 0.083 & 0.087 & 0.100 & 0.071 & 0.074 \\
\hline $\begin{array}{l}\mathrm{Mg} / \mathrm{Mg}+\mathrm{Fe}^{2+} \\
\mathrm{Cr} /(\mathrm{Cr}+\mathrm{Al})\end{array}$ & $\begin{array}{l}0.610 \\
0.563\end{array}$ & $\begin{array}{l}0.597 \\
0.556\end{array}$ & $\begin{array}{l}0.502 \\
0.569\end{array}$ & $\begin{array}{l}0.555 \\
0.519\end{array}$ & $\begin{array}{l}0.534 \\
0.503\end{array}$ & $\begin{array}{l}0.396 \\
0.504\end{array}$ & $\begin{array}{l}0.595 \\
0.526\end{array}$ & $\begin{array}{l}0.594 \\
0.528\end{array}$ \\
\hline
\end{tabular}

a $\mathrm{Fe}_{2} \mathrm{O}_{3}$ was calculated assuming stoichiometry.

524 are the most evolved, with all major silicate phases forming as microphenocrysts before extrusion.

Evidence for crystal fractionation is typical for basalts, as seen in the compositional zoning of plagioclase and clinopyroxene. Both equilibrium and nonequilibrium trends are present, especially in the clinopyroxenes, as would be expected in a collection of rocks with excep-
Table 8. Representative microprobe analyses of biotite from Hole 524.

\begin{tabular}{|c|c|c|c|c|}
\hline \multirow{2}{*}{$\begin{array}{l}\text { Cooling Unit } \\
\text { Sample } \\
\text { (interval in } \mathrm{cm} \text { ) }\end{array}$} & \multicolumn{4}{|c|}{ Upper sill } \\
\hline & $\begin{array}{c}524-29-2 \\
43-46\end{array}$ & $\begin{array}{c}524-30-2 \\
70-76\end{array}$ & $\begin{array}{c}524-31-1, \\
108-111\end{array}$ & $\begin{array}{c}524-31-2, \\
87-90\end{array}$ \\
\hline $\mathrm{SiO}_{2}$ (wt.\%) & 35.69 & 37.59 & 36.86 & 37.40 \\
\hline $\mathrm{TiO}_{2}$ & 6.73 & 5.47 & 5.99 & 5.14 \\
\hline $\mathrm{Al}_{2} \mathrm{O}_{3}$ & 11.13 & 10.54 & 12.38 & 10.97 \\
\hline $\mathrm{Cr}_{2} \mathrm{O}_{3}$ & - & 0.04 & - & - \\
\hline $\mathrm{FeO}$ & 23.16 & 17.52 & 18.70 & 19.03 \\
\hline $\mathrm{MnO}$ & 0.28 & 0.16 & 0.17 & 0.19 \\
\hline $\mathrm{MgO}$ & 7.44 & 12.65 & 11.50 & 12.27 \\
\hline $\mathrm{CaO}$ & 0.08 & 0.04 & 0.09 & 0.05 \\
\hline $\mathrm{Na}_{2} \mathrm{O}$ & 0.79 & 0.85 & 0.85 & 0.81 \\
\hline $\mathrm{K}_{2} \mathrm{O}$ & 8.39 & 8.69 & 8.24 & 8.66 \\
\hline$\Sigma$ & 93.69 & 93.55 & 94.78 & 94.16 \\
\hline $\mathrm{Si}(\mathrm{Z})$ & 5.69 & 5.82 & 5.64 & 5.77 \\
\hline $\mathrm{Ti}(\mathrm{Y})$ & 0.81 & 0.64 & 0.69 & 0.60 \\
\hline AlIV (Z) & 2.09 & 1.92 & 2.23 & 1.99 \\
\hline $\mathrm{Al}^{\mathrm{VI}}(\mathrm{Y})$ & - & - & - & - \\
\hline $\mathrm{Cr}$ & - & 0.004 & - & - \\
\hline $\mathrm{Fe}(\mathrm{Y})$ & 3.09 & 2.27 & 2.39 & 2.46 \\
\hline $\operatorname{Mn}(\mathrm{Y})$ & 0.04 & 0.02 & 0.02 & 0.02 \\
\hline $\mathrm{Mg}(\mathrm{Y})$ & 1.77 & 2.92 & 2.62 & 2.82 \\
\hline $\mathrm{Ca}(\mathrm{X})$ & 0.01 & 0.01 & 0.02 & 0.01 \\
\hline $\mathrm{Na}(\mathrm{X})$ & 0.24 & 0.25 & 0.25 & 0.24 \\
\hline K (X) & 1.71 & 1.72 & 1.61 & 1.70 \\
\hline$\Sigma Z$ & 7.78 & 7.74 & 7.87 & 7.76 \\
\hline$\Sigma \mathbf{Y}$ & 5.71 & 5.85 & 5.72 & 5.90 \\
\hline$\Sigma \mathrm{X}$ & 1.96 & 1.98 & 1.88 & 1.95 \\
\hline Number of analyses & 2 & 1 & 3 & 4 \\
\hline
\end{tabular}

tionally rapidly chilled margins as well as much more slowly cooled interiors of units such as thick flows and sills. The alkalic nature of the younger magma in Hole 524 is emphasized by the mantling of plagioclase with alkalic feldspars, the formation of veinlets filled with late magmatic residuum from which alkali feldspars of extreme compositions (nearly pure albite and K-feldspar) crystallized, and the development of late phase biotite and sodic amphibole. The temporary reversal in 
Table 9. Microprobe analyses of amphibole from Hole 524 .

\begin{tabular}{lrr}
\hline & Grain 1 & Grain 2 \\
\hline $\mathrm{SiO}_{2}$ (wt.\%) & 51.73 & 52.79 \\
$\mathrm{TiO}_{2}$ & 0.96 & 0.99 \\
$\mathrm{Al}_{2} \mathrm{O}_{3}$ & 0.59 & 0.59 \\
$\mathrm{Cr}_{2} \mathrm{O}_{3}$ & $<0.01$ & $<0.01$ \\
$\mathrm{FeO}_{\text {tot }}$ & 20.81 & 20.66 \\
$\mathrm{MnO}$ & 0.48 & 0.48 \\
$\mathrm{MgO}$ & 10.81 & 11.15 \\
$\mathrm{CaO}$ & 4.14 & 4.36 \\
$\mathrm{Na}_{2} \mathrm{O}$ & 5.72 & 5.29 \\
$\mathrm{~K}_{2} \mathrm{O}$ & 0.59 & 0.61 \\
$\Sigma$ & 95.84 & 96.93
\end{tabular}

Structural formulae ${ }^{\mathrm{a}}$

\begin{tabular}{lll}
$\mathrm{Si}(\mathrm{Z})$ & 7.919 & 7.956 \\
$\mathrm{AlIV}(\mathrm{Z})$ & 0.081 & 0.044 \\
$\mathrm{Al}$ VI $(\mathrm{Y})$ & 0.026 & 0.060 \\
$\mathrm{Ti}(\mathrm{Y})$ & 0.111 & 0.104 \\
$\mathrm{Fe}+3$ & - & - \\
$\mathrm{Mg}(\mathrm{Y})$ & 2.467 & 2.505 \\
$\mathrm{Fe}^{+2}(\mathrm{Y})$ & 2.665 & 2.605 \\
$\mathrm{Mn}(\mathrm{Y})$ & 0.062 & 0.061 \\
$\mathrm{Na}(\mathrm{M} 4)(\mathrm{X})$ & 0.990 & 0.952 \\
$\mathrm{Na}(\mathrm{A})(\mathrm{X})$ & 0.707 & 0.593 \\
$\mathrm{Ca}(\mathrm{X})$ & 0.678 & 0.704 \\
$\mathrm{~K}(\mathrm{X})$ & 0.116 & 0.118 \\
$\Sigma Z$ & 8.000 & 8.000 \\
$\Sigma \mathrm{Z}$ & 5.331 & 5.335 \\
$\Sigma \mathrm{X}$ & 2.491 & 2.367 \\
\hline $\mathrm{a}$ Positive charge $=46$, all $\mathrm{Fe}$ as \\
\multicolumn{2}{l}{ Fe }
\end{tabular}

Table 10A. Electron microprobe analyses of glass and plagioclase microphenocryst outer rims.

\begin{tabular}{lrrr}
\hline & Glass & $\begin{array}{c}\text { Plagioclase } \\
\text { grain 1 }\end{array}$ & $\begin{array}{c}\text { Plagioclase } \\
\text { grain 2 }\end{array}$ \\
\hline $\mathrm{SiO}_{2}$ (wt. \%) & 50.06 & 50.37 & 49.58 \\
$\mathrm{TiO}_{2}$ & 1.45 & 0.10 & 0.11 \\
$\mathrm{Al}_{2} \mathrm{O}_{3}$ & 14.50 & 30.51 & 30.85 \\
$\mathrm{FeO}_{\text {tot }}$ & 9.11 & 0.57 & 0.50 \\
$\mathrm{MnO}$ & 0.09 & 0.00 & 0.05 \\
$\mathrm{MgO}$ & 7.57 & 0.34 & 0.32 \\
$\mathrm{CaO}$ & 12.16 & 14.62 & 14.93 \\
$\mathrm{Na}_{2} \mathrm{O}$ & 2.83 & 3.26 & 3.35 \\
$\mathrm{~K}_{2} \mathrm{O}$ & 0.13 & 0.03 & 0.06 \\
$\Sigma$ & 97.90 & 99.80 & 99.75 \\
\hline
\end{tabular}

a Average of three spots.

Table 10B. Temperature of plagioclase-glass equilibration. Values are the same for both grains.

\begin{tabular}{llc}
\hline \multicolumn{1}{c}{ Technique } & $\begin{array}{c}\text { Water and } \\
\text { pressure } \\
\text { conditions }\end{array}$ & $\begin{array}{c}\text { Equilibration } \\
\text { temperature } \\
\left({ }^{\circ} \mathrm{C}\right)\end{array}$ \\
\hline Drake (1976) & Dry, 1 bar & 1299 \\
Kudo-Weill (1970) & Dry, 1 bar & 1332 \\
Kudo-Weill (1970) & $0.5 \mathrm{~kb} \mathrm{H} \mathrm{H}_{2} \mathrm{O}$ & 1278 \\
Kudo-Weill (1970) & $1 \mathrm{~kb} \mathrm{H} \mathrm{H}_{2} \mathrm{O}$ & 1210 \\
Kudo-Weill (1970) & $5 \mathrm{~kb} \mathrm{H} \mathrm{O}$ & 986 \\
\hline
\end{tabular}

Table 11. Fe-Ti oxide geothermometry.

\begin{tabular}{lcccrc}
\hline $\begin{array}{c}\text { Sample } \\
\text { (interval in cm) }\end{array}$ & $\begin{array}{c}\text { Cooling } \\
\text { Unit }\end{array}$ & $\begin{array}{c}\text { Ulvospinel in } \\
\text { titanomagnetite } \\
(\mathrm{mol} . \%)\end{array}$ & $\begin{array}{c}\text { Hematite in } \\
\text { ilmenite } \\
(\mathrm{mol} . \%)\end{array}$ & $\mathrm{T}\left({ }^{\circ} \mathrm{C}\right)$ & $-\log \mathrm{f}_{2}$ \\
\hline $519 \mathrm{~A}-7-2,46-58$ & 1 & 63.57 & 10.65 & 1052 & 10.1 \\
$519 \mathrm{~A}-9-4,77-80$ & 4 & 65.68 & 8.05 & 1027 & 10.6 \\
$524-28-3,70-72$ & Pillow & 50.15 & 9.54 & 930 & 11.8 \\
$524-28-3,70-72$ & Pillow & 48.34 & 9.54 & 918 & 11.9 \\
$524-28-3,70-72$ & Pillow & 53.38 & 9.54 & 957 & 11.4 \\
$524-28-3,70-72$ & Pillow & 48.75 & 13.62 & 991 & 10.5 \\
$524-28-3,70-72$ & Pillow & 51.83 & 13.54 & 1019 & 10.1 \\
$524-31-1,108-111$ & Upper sill & 63.69 & 5.40 & 948 & 12.2 \\
$524-31-1,108-111$ & Upper sill & 65.22 & 5.07 & 951 & 12.2 \\
\hline
\end{tabular}

Fe enrichment in the progressive zonation of clinopyroxene in the lower sill of Hole 524 is interesting but unexplained.

Overall, the rocks from each hole are texturally and mineralogically distinctive in minor ways; their variations reflect basic differences in bulk chemistry. The differences are visible chiefly in the quenched rocks, where the pre-eruption phases can be distinguished, whereas in the more slowly cooled rocks the tholeiites all tend toward a typical fundamentally diabasic texture. Insofar as it has been studied, the detailed chemistry of the mineral phases is typical for MORB, except for the mentioned reversal in the $\mathrm{Fe}$ enrichment in clinopyroxene. Basically the patterns conform to the known phase relations of the major rock-forming minerals. However, such details as the zoning in spinels and opaque minerals, as well as the exsolution relations of the latter, were not studied. The inclusion of iron in plagioclase appears to reflect the initiation of crystallization of clinopyroxene and $\mathrm{Fe}-\mathrm{Ti}$ oxides in a fashion similar to that of other Mid-Atlantic Ridge tholeiites. In addition, the titanium content of clinopyroxene seems to reflect the beginning of the formation of $\mathrm{Fe}-\mathrm{Ti}$ oxides. A magnesium number of 0.75 for clinopyroxene appears to be an average value at which $\mathrm{Fe}-\mathrm{Ti}$ oxides start crystallizing in Leg 73 tholeiites, and this number is in keeping with the value reported for similar rocks in the North Atlantic. However, that number is variable, as shown by detailed studies of individual crystals in different flow units of the same composition, and it probably reflects such variable factors as oxygen fugacity and perhaps cooling rate.

\section{ACKNOWLEDGMENTS}

The authors wish to express appreciation for a most constructive review of this article by Dr. Maryellen Cameron. M. Carman also benefited greatly from discussions with Dr. Donald Elthon on the interpretation of the compositions and phase relations of the minerals. Thanks are also due to Dr. John C. Butler, who graciously performed the calculations for plagioclase geothermometry, to Mr. Thomas See, who patiently made a large number of the point counts for modal analyses, and to Ms. Amanda Graham, who typed the manuscript, including the tables, with exceptional speed and accuracy.

\section{REFERENCES}

Ayuso, R. A., Bence, A. E., and Taylor, S. R., 1976. Upper Jurassic tholeiitic basalts from DSDP Leg 11. J. Geophys. Res., 81: 4305-4325.

Barager, W. R. A., Plant, A. G., Pringle, G. J., and Schau, M., 1977. Petrology and alteration of selected units of Mid-Atlantic 
Ridge basalts sampled from Sites 332 and 335, DSDP. Can. J. Earth Sci., 14:837-874.

Bryan, W. B., 1972. Morphology of quench crystals in submarine basalts. J. Geophys. Res., 77:5812-5819.

Carman, M. F., Cameron, M., Gunn, B., Cameron, K. L., and Butler, J. C., 1975. Petrology of the Rattlesnake Mountain Sill, Big Bend National Park, Texas. Geol. Soc. Am. Bull., 86:177-193.

Clague, D. A., Fisk, M. R., and Bence, A. E., 1980. Mineral chemistry of basalts from Ojin, Nintoku, and Suiko seamounts, Leg 55 DSDP. In Jackson, E. D., Koizumi, I., et al., Init. Repts. DSDP, 55: Washington (U.S. Govt. Printing Office), 607-637.

Donnelly, T. W., 1972. Deep-water, shallow-water, and sub-aerial island-arc vulcanism: an example from the Virgin Islands. In Shagam, R., Hargraves, R. B., and Morgan, W. J. (Eds.), Studies in Earth and Space Sciences. Mem. Geol. Soc. Am., 132:401-414.

Donnelly, T. W., Francheteau, J., Bryan, W., Robinson, P., Flower, M., Salisbury, M., et al., 1980. Init. Repts. DSDP, 51, 52, 53: Washington (U.S. Govt. Printing Office).

Drake, M. J., 1976. Plagioclase-melt equilibria. Geochim. Cosmochim. Acta, 40:457-466.

Genkin, A. D., Laputina, I. P., and Pertsev, N. N., 1980. Opaque minerals in basalts from Holes 417D and 418A. In Donnelly, $\mathrm{T}$., Francheteau, J., Bryan, W., Robinson, P., Flower, M., Salisbury, M., et al., Init. Repts. DSDP, 51, 52, 53, Pt 2: Washington (U.S. Govt. Printing Office), 1431-1450.

Ghiorso, M. S., and Carmichael, I. S. E., 1981. A Fortran IV computer program for evaluating temperatures and oxygen fugacities from the compositions of coexisting iron-titanium oxides. Comput. Geosci., 7:123-129.

Hawthorne, F. C., 1981. Crystal chemistry of the amphiboles. In Veblen, D. R. (Ed.), Amphiboles and Other Hydrous Pyriboles-Mineralogy, Rev. Mineral., 9A:1-102.

Hsü, K. J., He, Q., McKenzie, J. A., Weissert, H., Perch-Nielsen, K., Oberhansli, H., Kelts, K., LaBrecque, J., Tauxe, L., Krähenbühl, U., Percival, S. F., Wright, R., Karpoff, A. M., Petersen, N., Tucker, P., Poore, R. T., Gombos, A. M., Pisciotto, K., Carman, M. F.; and Schreiber, E., 1982. Mass mortality and its environmental and evolutionary consequences. Science, 216:249-256.

Johnson, H. P., and Hall, J. M., 1978. A detailed rock magnetic and opaque mineralogy study of the basalts from the Nazca Plate. Geophys. J. R. Astron. Soc., 52:45-64.

Kirkpatrick, R. J., 1979. Processes of crystallization in pillow basalts, Hole 396B, DSDP Leg 46. In Dmitriev, L., Heirtzler, J., et al., Init. Repts. DSDP, 46: Washington (U.S. Govt. Printing Office), 271-282.

Kono, M., Clague, D., and Larson, E. E., 1980. Fe-Ti oxide mineralogy of DSDP Leg 55 basalts. In Jackson, E. D., Koizumi, I., et al., Init. Repts. DSDP, 55: Washington (U.S. Govt. Printing Office), 639-652.
Kudo, A. M., and Weill, D. F., 1970. An igneous plagioclase thermometer. Contrib. Mineral. Petrol., 25:52-65.

Kushiro, I., and Nakamura, Y., 1970. Petrology of some lunar crystalline rocks. In Levinson, A. A. (Ed.), Proc. Apollo 11 Lunar Sci. Conf. (Vol. 1): New York (Pergamon Press), 607-626.

Lofgren, G., Donaldson, C. H., Williams, R. J., Mullins, O., and Usselman, T. M., 1974. Experimentally reproduced textures and mineral chemistry of Apollo 15 quartz normative basalts. Proc. Fifth Lunar Conf. (Suppl. 5 to Vol. 1), Geochim. Cosmochim. Acta, 549-567.

Natland, J. H., 1979. Crystal morphologies in basalts from DSDP Site $395,23^{\circ} \mathrm{N}, 46^{\circ} \mathrm{W}$, Mid-Atlantic Ridge. In Melson, W. G., Rabinowitz, P. D., et al., Init. Repts. DSDP, 45: Washington (U.S. Govt. Printing Office), 423-445.

Osborn, E. F., 1959. Role of oxygen pressure in the crystallization and differentiation of basaltic magma. Am. J. Sci., 257:609-647.

1962. Reaction series for subalkaline igneous rocks based on different oxygen pressure conditions. Am. Mineral. , 47:211-226.

Ridley, W. I., 1977. The crystallization trends of spinels in Tertiary basalts from Rhum and Muck and their petrogenetic significance. Contrib. Mineral. Petrol., 64:243-255.

Ridley, W. I., Perfit, M. R., and Adams, M. L., 1976. Petrology of basalts from Deep Sea Drilling Project, Leg 38. In Talwani, M., Udintsev, G., et al., Init. Repts. DSDP, 38: Washington (U.S. Govt. Printing Office), 731-740.

Sato, H., 1979. Segregation vesicles and immiscible liquid droplets in ocean-floor basalt of Hole 396B, IPOD/DSDP Leg 46. In Dmitriev, L., Heirtzler, J., et al., Init. Repts. DSDP, 46: Washington (U.S. Govt. Printing Office), 283-291.

Sigurdsson, H., and Schilling, J. G., 1976. Spinels in Mid-Atlantic Ridge basalts: chemistry and occurrence. Earth Planet. Sci. Lett., 29:7-20.

Sinton, J. M., and Byerly, G. R., 1980. Mineral compositions and crystallization trends in DSDP Holes 417D and 418A. In Donnelly, T., Francheteau, J., Bryan, W., Robinson, P., Flower, M., Salisbury, M., et al., Init. Repts. DSDP, 51, 52, 53, Pt. 2: Washington (U.S. Govt. Printing Office), 1039-1054.

Smith, D., and Lindsley, D. H., 1971. Stable and metastable augite crystallization trends in a single basalt flow. Am. Mineral., 56: 225-233.

Smith, J. V., 1974. Feldspar Minerals. Vol. 1: Crystal Structure and Physical Properties: New York (Springer Verlag).

Smith, R. E., 1967. Segregation vesicles in basaltic lava. Am. J. Sci., 265:696-713.

Date of Initial Receipt: August 5, 1982 


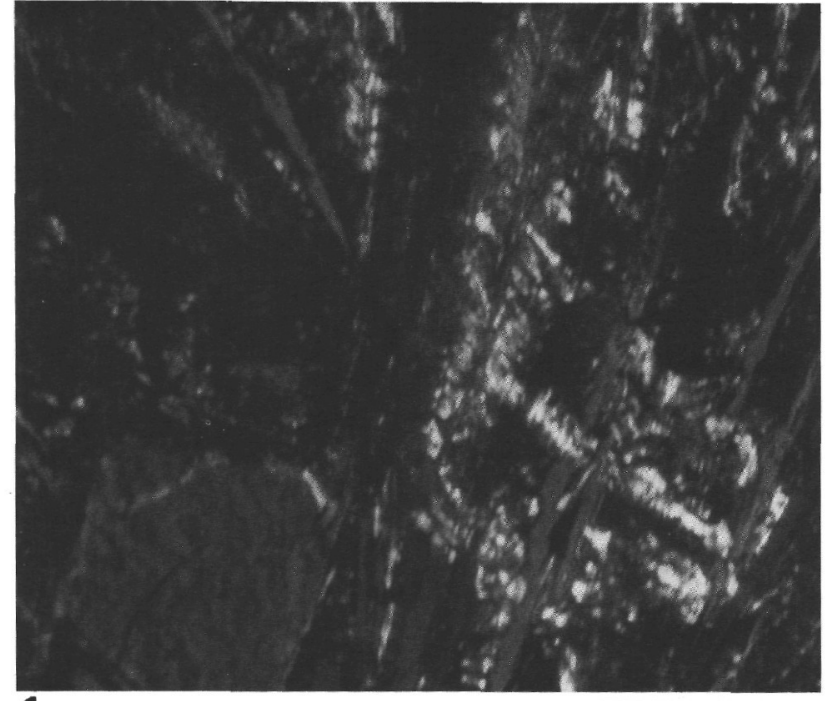

1

$0.05 \mathrm{~mm}$

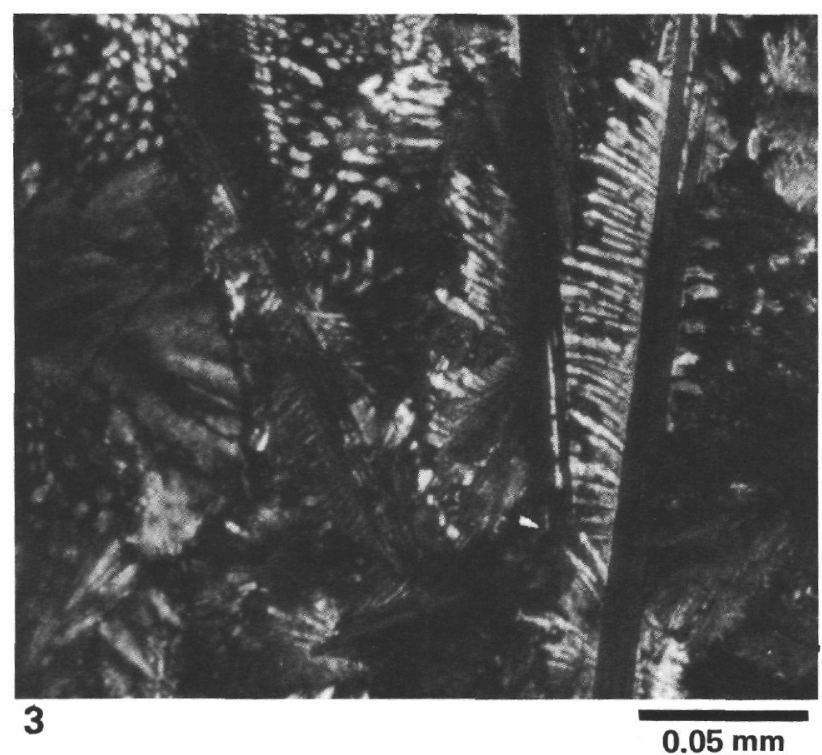

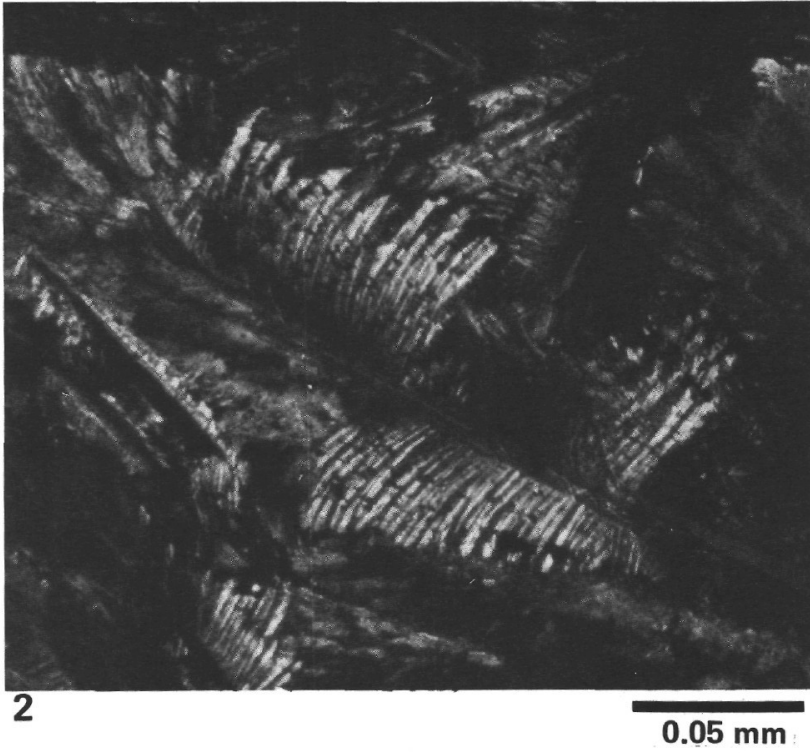

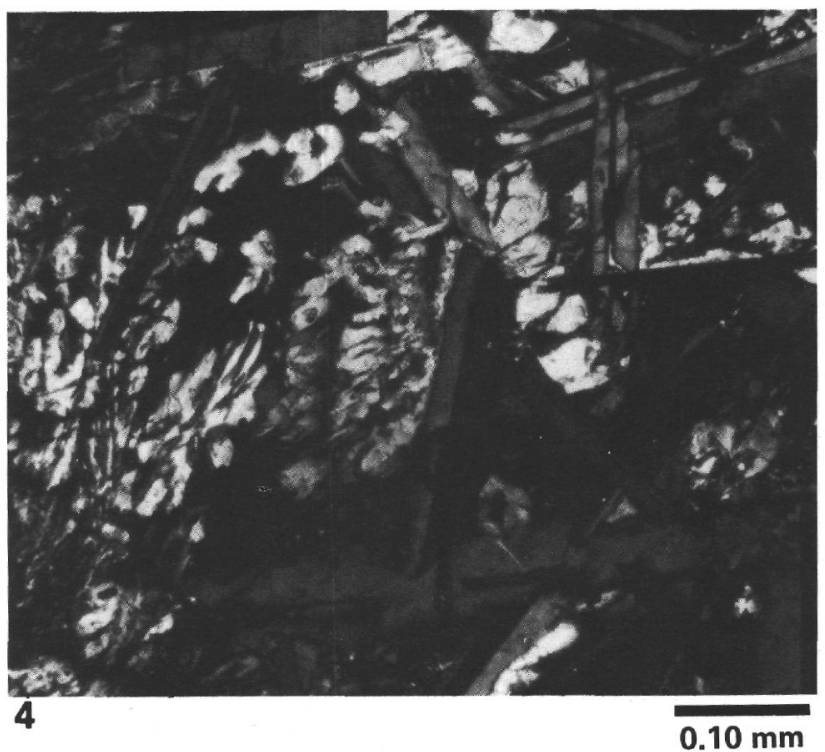

Plate 1. Textures in Leg 73 basalts. 1. Simple dendritic clinopyroxene (white) in variole with olivine core (dark gray patch in lower left corner). Sample 520-30-1, 89-95 cm, $2 \mathrm{~cm}$ from glassy Zone 1. Crossed polarizers. See Pl. 2, Fig. 5 for low power view. 2. Plumose dendritic (Zone 5) clinopyroxene (white) in fine quench texture. Sample 522B-3-3, 76-78 cm, top of pillow, Cooling Unit 3. Crossed polarizers. 3. Comb-shaped dendritic clinopyroxene (white) in fine quench texture, plumose dendritic Zone 5. Sample 522B-3-3, 138-142 cm, top of pillow, Cooling Unit 4. Crossed polarizers. 4. Coarse dendritic (Zone 6) clinopyroxene (white) in coarse quench texture. Note thick dendritic augite enclosing end of plagioclase just right of center, suggesting transition to subophitic texture. Sample 519A-9-1, 58-60 cm, interior of flow, Cooling Unit 4, 0.5 m below top margin. Crossed polarizers. 

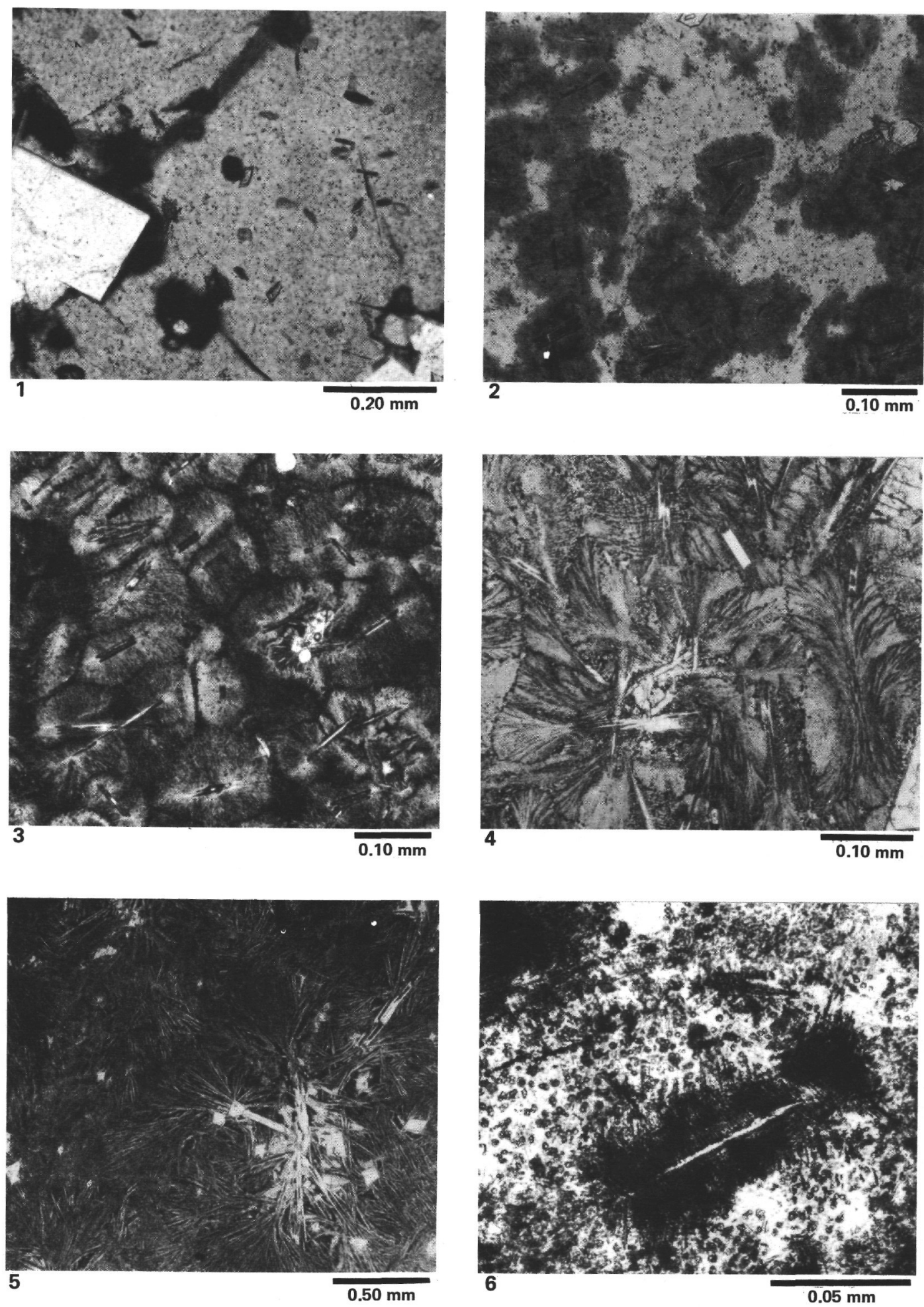

Plate 2. Textures in Leg 73 basalts. 1. Microphenocrysts in glassy Zone 1. First-generation (large boxy grains at left edge) and second-generation plagioclase and olivine microphenocrysts (small elongate and equant grains) partially bounded by spherulitic overgrowths. Sample 519A-37,CC, top of flow, Cooling Unit 1. 2. Spherulites in glassy spherulitic Zone 2. Cores of spherulites are mostly second-generation plagioclase. Sample $519 \mathrm{~A}-7-1,15-18 \mathrm{~cm}$, top of flow, Cooling Unit 1 . 3. Spherulites in very fine quench texture coalesced spherulitic Zone $3,0.75 \mathrm{~mm}$ from glassy zone. Same sample as Fig. 2. 4. Sheaf-shaped bowtie and fan-shaped spherulites in fine quench texture, sheaf-shaped spherulitic Zone 4. Sample 522B-4-2, 68-71 cm, top of flow, Cooling Unit 7. 5. Fine quench texture, consisting of radiating plagioclase fibers, many centered on an equant euhedral olivine microphenocryst. Sparse ovoid dark areas are spherulites composed chiefly of augite dendrites. Same sample as Pl. 1, Fig. 1. 6. Reticulate spherulite in devitrified glass matrix in glassy spherulitic Zone 2. Sample 524-28-3, 80-84 cm, pillow margin of alkalic pillow unit. 

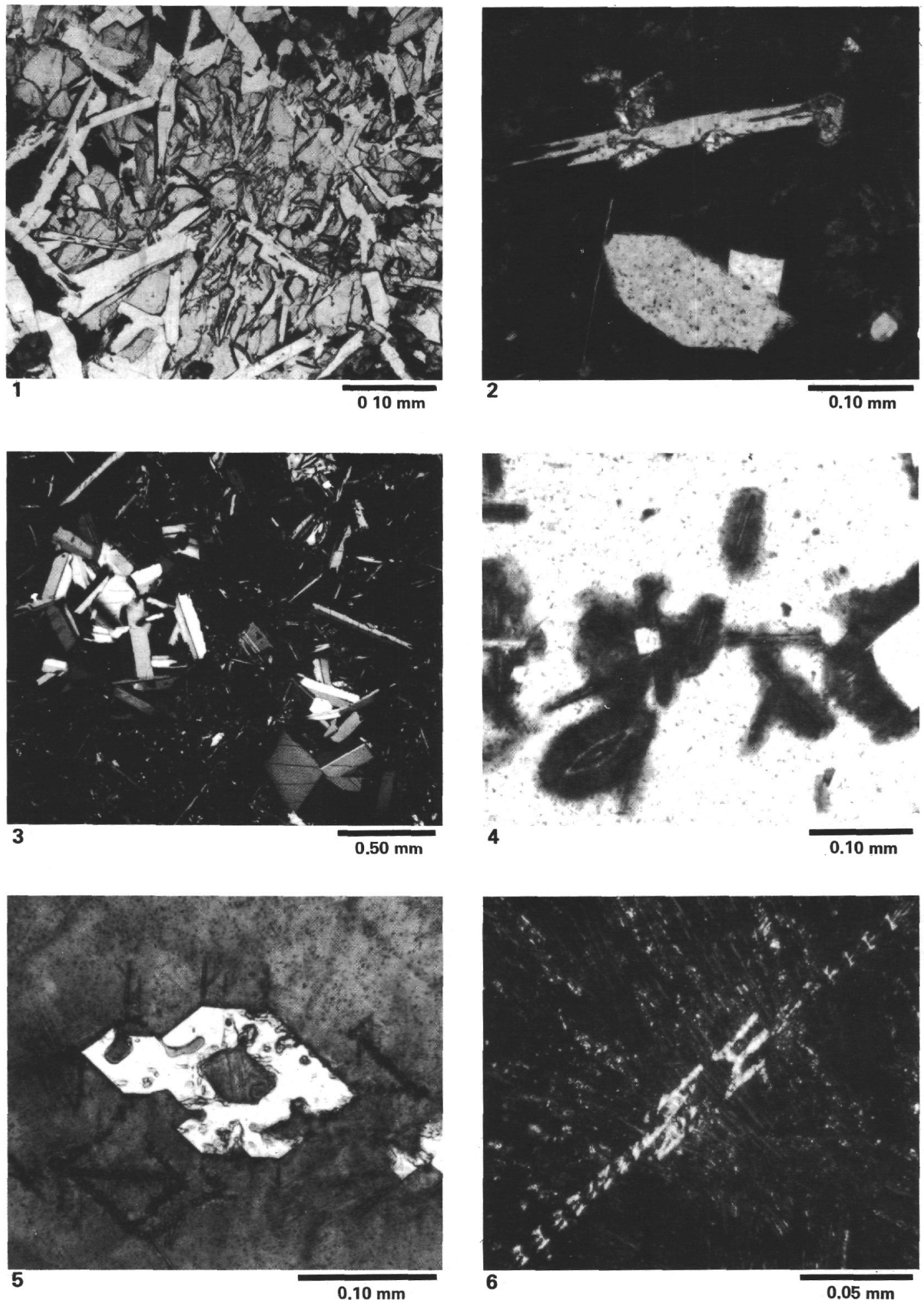

Plate 3. Textures in Leg 73 basalts. 1. Ophitic texture with oikocryst of clinopyroxene (light gray), filling most of field, bordered by intersertal patches (black). Sample 519A-7-2, 50-52 cm, flow interior, Cooling Unit 1. 2. First- (lower) and second- (upper) generation plagioclase microphenocrysts in sheaf-shaped spherulitic Zone 4. Second-generation grain shows typical tapered terminations, is intergrown with anhedral olivine, and has several thin albite twin lamellae. First-generation grains are untwinned. Sample 519A-7-1, 20-26 cm, $7 \mathrm{~mm}$ from glassy spherulitic zone, flow margin, Cooling Unit 1. 3. First-generation (stubby, solid, and glomerocrystic) and second-generation (elongate, thin, skeletal, single, and seriate) plagioclase microphenocrysts. Sample $522 \mathrm{~B}-4-2,93-95 \mathrm{~cm}, 25 \mathrm{~cm}$ from flow margin, Cooling Unit 7. Crossed polarizers. 4. Radial hollow second-generation plagioclase microphenocrysts intergrown with equant olivine at core of cluster (left of center). Large first-generation plagioclase on right margin. All microphenocrysts are spherulitically overgrown. Glassy spherulitic Zone. Same sample as Fig. 2 . 5. Resorbed(?) olivine microphenocryst surrounded by dendritic chains of olivine paralleling crystallographic directions of the larger grain. Sample 520-30-1, 89-95 cm, pillow margin, glassy spherulitic Zone 2. 6. Chain-link olivine in mesostasis of plagioclase fibers and augite dendrites in variolitic zone, $2 \mathrm{~cm}$ from glassy Zone 1. Same sample as Fig. 5. Crossed polarizers. 

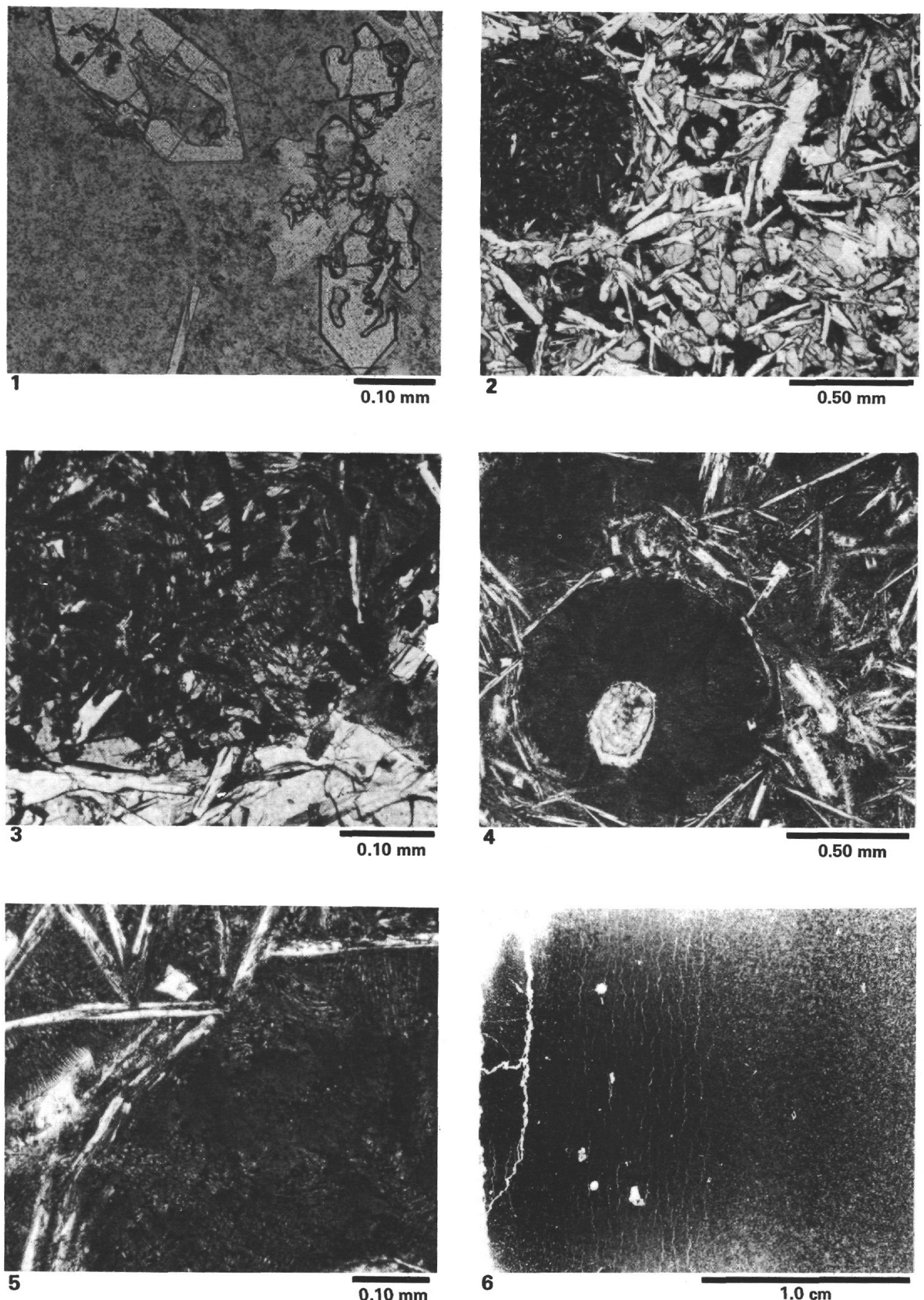

Plate 4. Textures in Leg 73 basalts. 1. Skeletal (resorbed?) olivine in glassy Zone 1. Sample 522B-3-3, 138-142 cm, lower rim of pillow, Cooling Unit 4. 2. Segregation vesicle in seriate, subophitic to intergranular, intersertal basalt. Sample 522B-4-1, 4-6 cm, interior of flow, Cooling Unit 5. 3. Detail of segregation vesicle. Abundant Fe-Ti oxide grains, sparse plagioclase microlites, and dendritic clinopyroxene matrix. Same sample as Fig. 2. 4. Segregation vesicles in microphyric, plumose dendritic (Zone 5) basalt. Sample 522B-3-3, 135-137 cm, lower part of pillow, Cooling Unit 3. 5. Detail of segregation vesicle. Relatively minor equant Fe-Ti oxide grains in an abundant dendritic clinopyroxene and spherulite matrix. Same sample as Fig. 4. 6. Contraction fractures in pillow margin. Left side is close to pillow rim, having coalesced spherulitic texture of Zone 3. Note how cracks broaden and become more widely spaced to the right, away from rim (see also the Hole 524 site chapter, Pl. 1, Fig. 4). Most cracks are filled with calcite or smectite, although broader ones contain some feldspar. Thick calcite-filled fractures at left, near rim, cut across smaller fractures and are typical of borders of rock units with quench textures. Sample 524-28-3, 102-105 cm; alkalic basalt pillow margin. 

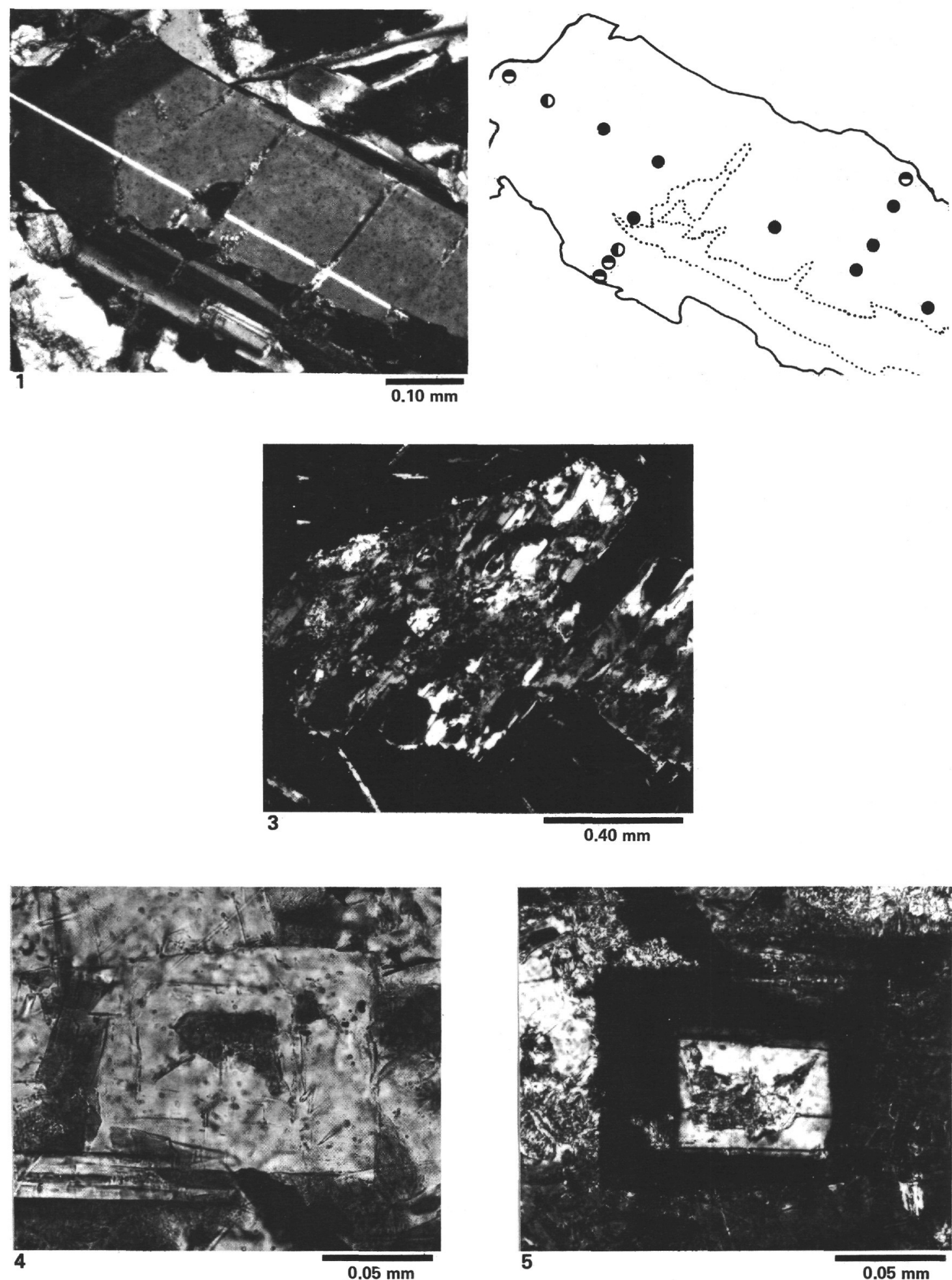

Plate 5. Textures in Leg 73 basalts. 1. Zoned plagioclase microphenocryst with compositional variation illustrated in Fig. 8A. Sample 524-34-2, 18-21 cm, interior of sill, lower part, lower sill. 2. Overlay for Fig. 1, showing location of microprobe analyses. Refer to Fig. 8A for meaning of symbols. 3. Corroded plagioclase xenocryst partially replaced by inclusion-filled K-feldspar (mottled gray). Black spots are plucked areas. Sample 524-28-3, 70-72, alkalic basalt, pillow unit. Crossed polarizers. 4. Epitaxially mantled plagioclase. Mantle consists of Na-sanidine. Section cut perpendicular to the a crystallographic axis. In mantle, optical axial plane is north-south and $2 \mathrm{~V}_{\mathrm{X}}$ close to $50^{\circ}$. Sample $524-31-1$, 108-111 cm, sill interior, upper sill. Plain light. 5. Same as Fig. 4, with crossed polarizers to illustrate alkali feldspar mantle (black). 

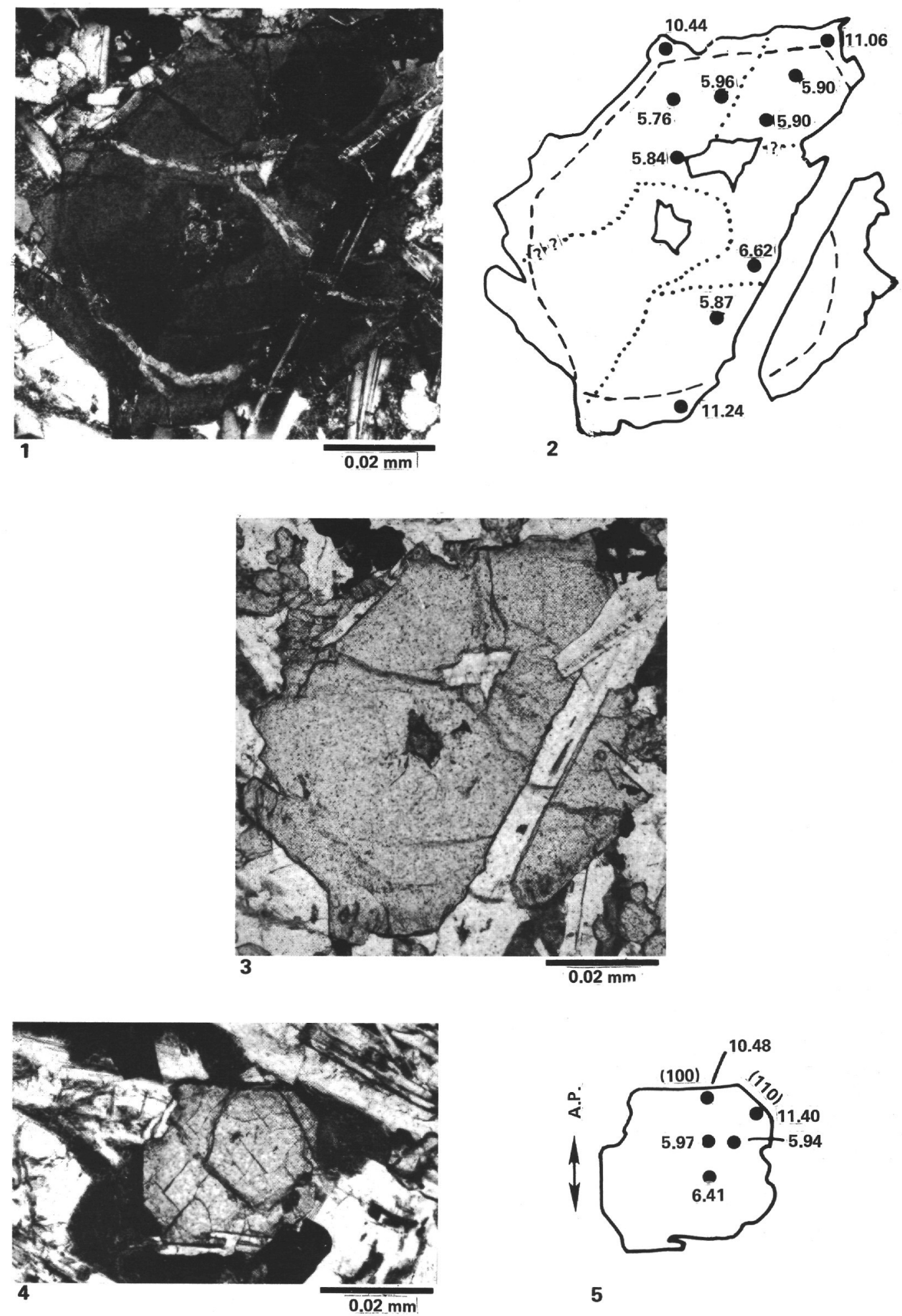

5

Plate 6. Textures in Leg 73 basalts. 1. Zoned clinopyroxene with compositional variation illustrated in Fig. 11. Grain cut parallel to c crystallographic axis. Displays both concentric and sector zoning. Sample 524-33-1, 112-116 cm, sill interior, lower sill, central part. Crossed polarizers. 2. Overlay of Fig. 1, displaying location of microprobe analyses. Dashed line traces concentric zoning, and dotted lines trace sector zoning. Numbers refer to wt.\% total iron as FeO. 3. Same as Figure 1. Plain light. 4. Zoned clinopyroxene with compositional variation illustrated in Fig. 11. Grain cut perpendicular to c crystallographic axis. Sample 524-33-1, 8-11 cm, sill interior, lower sill, upper part. Plain light. 5. Overlay of Fig. 4, displaying location of microprobe analyses. Optic axial plane orientation, (100) pinacoid and (110) prism faces labeled. Numbers refer to wt. \% total iron as $\mathrm{FeO}$. 

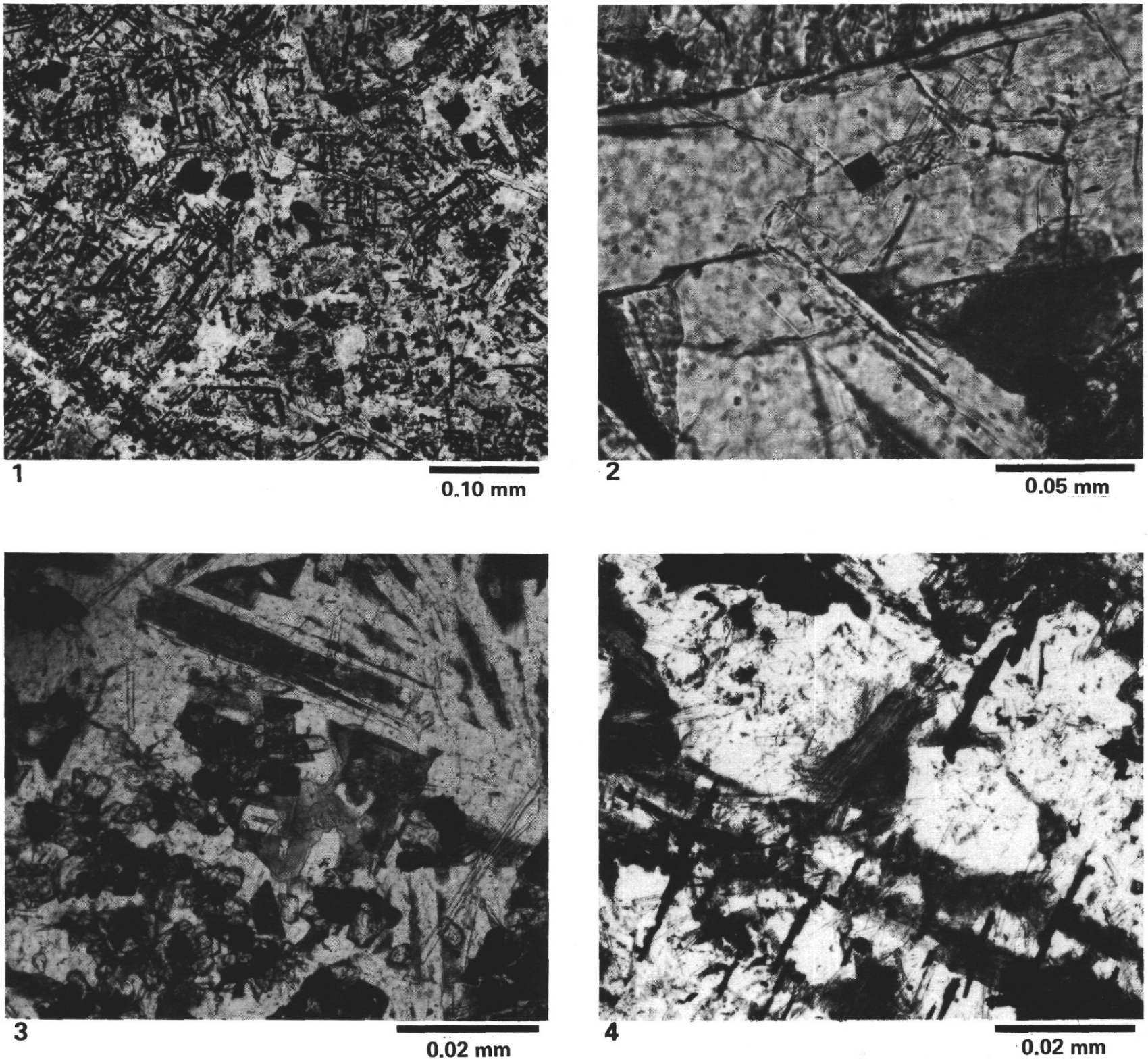

Plate 7. Textures in Leg 73 basalts. 1. Reticulate ilmenitic Fe-Ti oxide in pillow $10 \mathrm{~cm}$ from the rim. Sample 524-28-3, 93-97 cm, alkalic basalt. 2. Spinel inclusion in plagioclase microphenocryst. Sample $519 \mathrm{~A}-7-2,46-58 \mathrm{~cm}$, flow interior, Cooling Unit 1 . 3. Biotite in groundmass (light gray, anhedral in center of photo). Sample 524-31-2, 87-90 cm, sill interior, upper sill. 4. Amphibole in groundmass (dark gray, prismatic with frayed ends in center of photo). Sample 524-30-2, 126-129 cm, sill interior, upper sill. 